Constança de Carvalho Belchior

\title{
Gestão Costeira Integrada- Estudo de Caso do Projeto ECOMANAGE na Região Estuarina de Santos-São Vicente, SP, Brasil
}

Dissertação apresentada ao Programa de Pós-Graduação em Ciência Ambiental da Universidade de São Paulo, como parte dos requisitos para a obtenção do Título de Mestre em Ciência Ambiental.

Orientadora:

Profa Dra. Sônia Maria Flores Gianesella

São Paulo

2008 
Universidade de São Paulo

PROCAM

Gestão Costeira Integrada- Estudo de Caso do Projeto ECOMANAGE na Região Estuarina de Santos-São Vicente, SP, Brasil

Constança de Carvalho Belchior

Dissertação apresentada ao Programa de Pós-Graduação em Ciência Ambiental da Universidade de São Paulo, como parte dos requisito para a obtenção do Título de Mestre em Ciência Ambiental.

Aprovada em

Comissão Julgadora

Prof. Dr.

Instituição:
Prof. Dr.

Instituição:

Universidade de São Paulo

Profa Livre-Docente do Depto. de

Oceanografia Biológica do Instituto Oceanográfico

da Universidade de São Paulo 


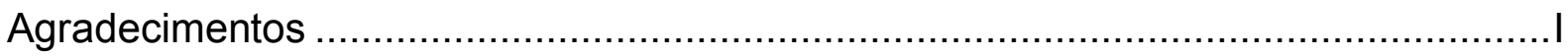

Resumo

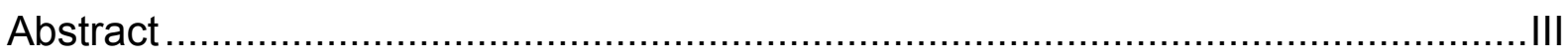

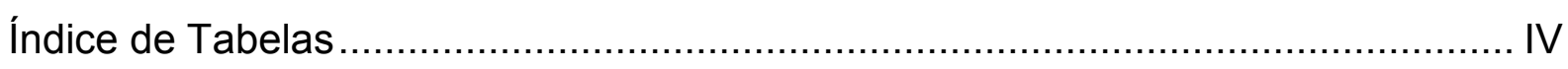

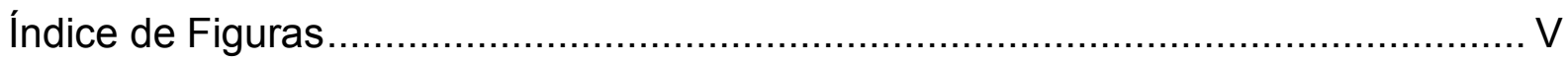

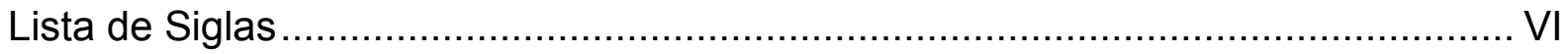

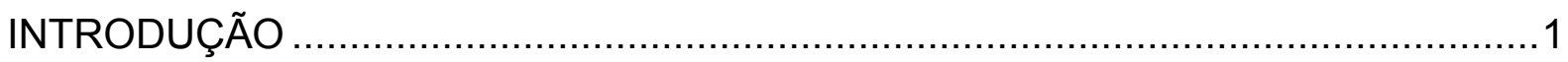

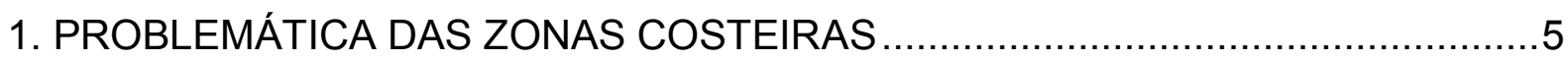

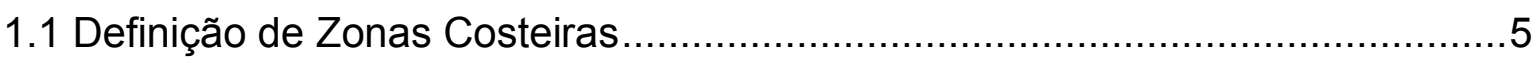

1.2 A Importância das Zonas Costeiras ...........................................................

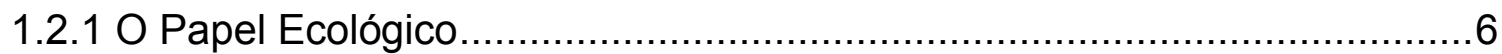

1.2.2 A Importância Socioeconômica.....................................................

1.3 Estado das Zonas Costeiras e Causas da Degradação Ambiental .................10

1.3.1 Situação Atual das Zonas Costeiras ..................................................10

1.3.2 Forçantes de Mudança e Principais Pressões ........................................13

1.3.2.1 Forçantes humanas ................................................................13

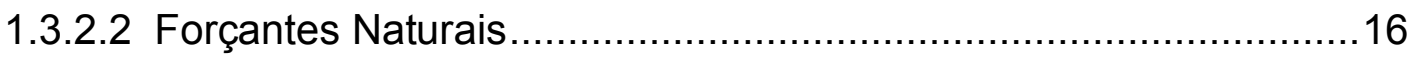

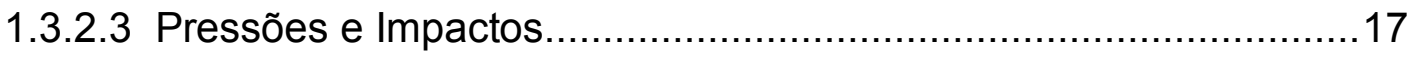

1.3.2 Tendências Previstas e Problemas Prioritários .....................................19

1.4 Mudanças no Contexto Mundial e a Necessidade de Integração na Procura de

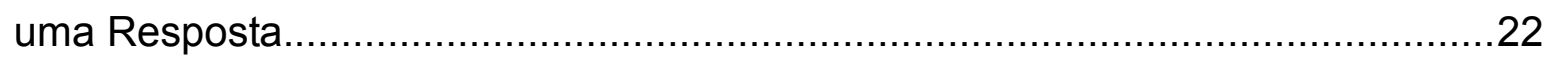

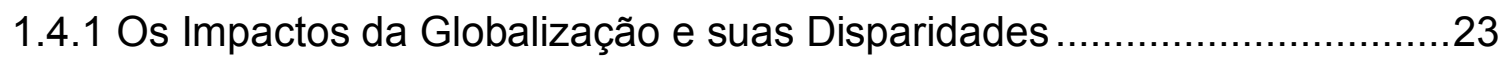

1.4.2 A Introdução da Sustentabilidade nas Agendas Políticas.......................24

1.4.3 O Reconhecimento das Mudanças Globais ........................................27

1.4.4 Mudanças Epistemológicas na Concepção do Mundo.............................27 2 - A GESTÃO COSTEIRA: ASPECTOS DA SUA EVOLUÇÃO E PARADIGMA

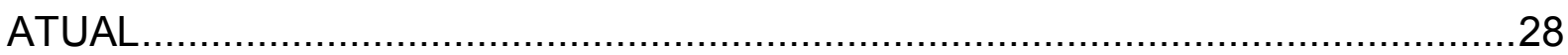

2.1 A História e Evolução da Gestão Costeira.................................................29

2.1.1 A gestão costeira como disciplina independente ...................................29

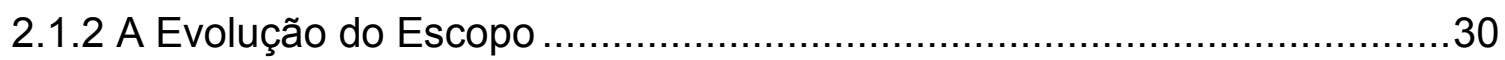

2.2 O Paradigma Atual: A Gestão Costeira Integrada ........................................32 


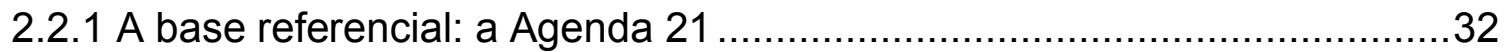

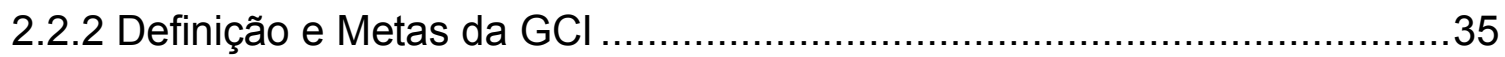

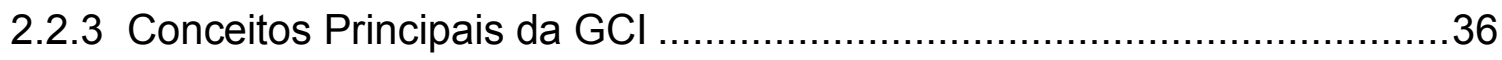

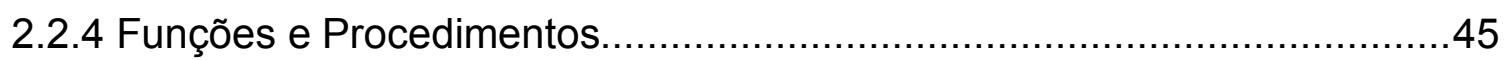

2.2.5 Fatores determinantes para uma implementação bem sucedida de $\mathrm{GCl} 48$ 2.2.6 A importância de projetos piloto para o processo de $\mathrm{GCl}$.......................50

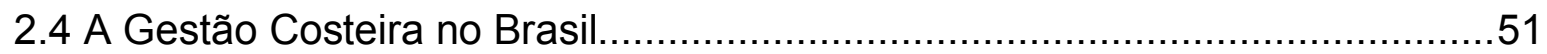

2.4.1 A Gênese da Gestão Costeira no Brasil e o Desenvolvimento das suas

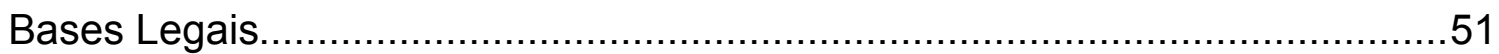

2.4.2 O Plano Nacional de Gerenciamento Costeiro........................................53

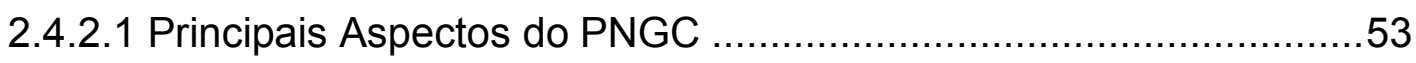

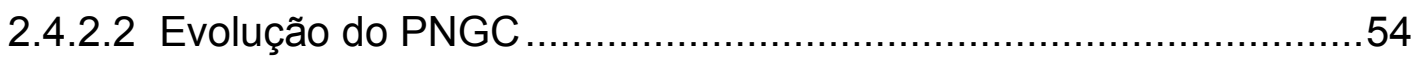

2.4.2.3 Principais resultados obtidos desde a implementação do PNGC ..57

2.4.3 Retrato do processo de implementação do GERCO.................................62

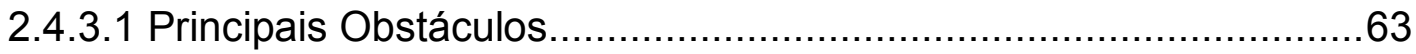

2.4.3.2 Potencialidades do GERCO e Caminhos Futuros...........................66

3. ACOMPANHAMENTO DO PROJETO ECOMANAGE E SUA RELEVÂNCIA PARA UMA ANÁLISE DO PROCESSO DA GCI NO BRASIL .........................................70

3.1 Estudo de Caso: o Projeto Ecomanage .......................................................

3.1.1 Descrição e Objetivos do Projeto ....................................................

3.1.2 Modelo Conceitual do Ecomanage ……….........................................

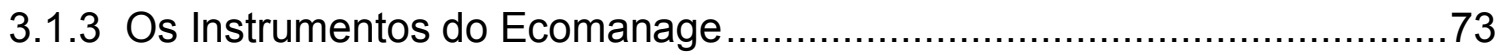

3.2 Desenvolvimento do Projeto Ecomanage na Baixada Santista .....................74

3.2.1 Descrição dos Principais Conflitos Socioambientais da Baixada Santista

3.2.2 Procedimentos da Implantação do Projeto Ecomanage na Baixada

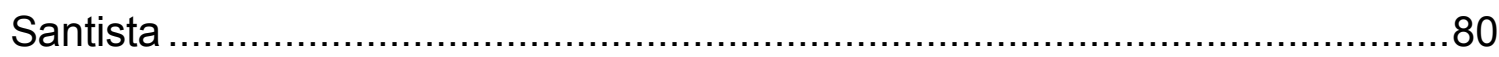

3.2.2.1 Os principais Passos do Desenvolvimento do Projeto .81

3.2.2.2 Considerações sobre o Desenvolvimento do Sistema de Apoio à Decisão

3.3 Avaliação das Dificuldades e Oportunidades da Implementação de um Projeto

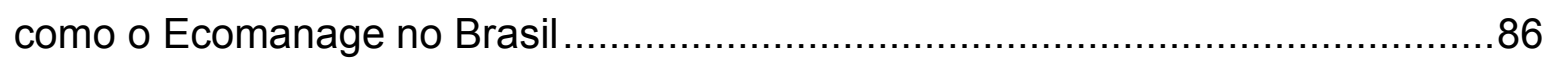

3.3.1 Análise das Principais Dificuldades de Implementação. ...........................87

3.3.2 Potencialidades Evidenciadas durante o Processo de Implementação ...92 


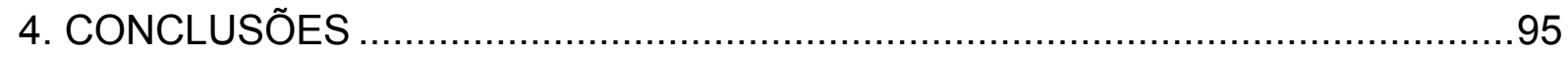

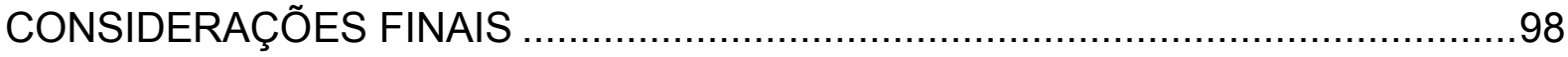

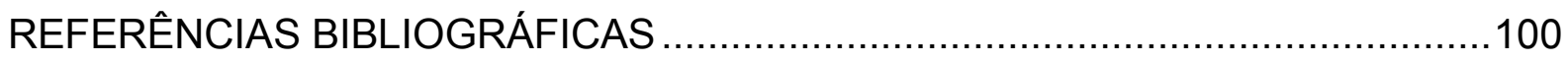


Dedico esta tese à minha avó Maria, que sempre teve tanto amor por esta terra brasileira e que me viu partír de Portugal para começar esta aventura. séi que me estás a ver de ai de cima a terminá-la. 


\section{Agradecimentos}

Aos meus pais, que me possibiltaram esta oportunidade e que apesar de nunca entenderem muito bem as minhas escolhas, sempre me deram liberdade para as tomar, orientando-me apenas com o seu juízo. Muito obrigada, mesmo...

À minha orientadora, Sônia, que quando decidiu aceitar orientar-me, não sabia na encrenca em que se estava metendo. Não tenho palavras pelo seu apoio e por sempre ter acreditado mim.

À Ale, cuja ajuda e comentários foram essenciais para a elaboração desta tese e que acabou por ficar minha parceirona durante o projeto. Espero poder retribuir-te um dia...

A toda a equipe do Ecomanage, por me ter deixado participar neste projeto fantástico e aliciante. Fica aqui um abraço especial para a minha turminha de Portugal e um ainda mais especial para o Marcos, companheiro, que sempre se preocupou comigo. Obrigada a todos.

Ao pessoal do Procam, sobretudo ao Luciano, por terem tido paciência para todas as minhas dúvidas e pedidos ao longo deste tempo todo. O Procam não seria o mesmo sem vocês.

À USP, enquanto instituição, por me ter aberto as portas e me ter facultado inúmeros dos seus recursos. Espero que este trabalho consiga espelhar esse investimento. Fica aqui um abraço especial para a equipe da biblioteca do IO, cujo sorriso e disponibilidade constante permanecerão inesquecíveis.

E por último, a todos os meus amigos, que tiveram a paciência de me acompanhar ao longo destes anos e permaneceram ao meu lado, apesar das minhas variações de humor e dos meus momentos de reclusão. 


\section{Resumo}

O presente trabalho pretende contribuir para a análise do processo de gestão costeira no Brasil, ao acompanhar e analisar a implementação de um projeto local de gestão costeira integrada - o projeto Ecomanage, que está sendo desenvolvido na região estuarina de Santos - São Vicente, SP (em fase final) e que pretende fornecer ferramentas gerenciais práticas e eficientes para auxiliar na tomada de decisão. A gestão costeira integrada, atual paradigma da gestão costeira mundial e cujos princípios foram incorporados pelo Programa Nacional de Gerenciamento Costeiro do Brasil, é um processo iterativo que vai se redefinindo ao longo do tempo e de acordo com a experiência. Para tal, é necessário que se concretizem avaliações quanto às dificuldades e oportunidades encontradas, de maneira a que os seus procedimentos sejam retificados de acordo e suas metas sejam cumpridas para se concretizar o seu objetivo maior, o de promover o desenvolvimento sustentável das zonas costeiras. Na avaliação efetuada do projeto Ecomanage verificou-se que a sua implementação foi fortemente influenciada por condicionantes de natureza político-institucional, técnico-administrativa e sócio-cultural, em muito comuns aos que têm sido apontados para o gerenciamento costeiro nacional e também mundial. No entanto, apesar das dificuldades, foi possível estabelecer uma importante colaboração com atores locais da região, tendo sido, inclusive, firmado parcerias com atores governamentais que irão possibilitar continuar o trabalho iniciado pelo projeto.

Descritores: zona costeira, gestão costeira integrada, sistema estuarino Santos São Vicente, participação pública, ferramentas gerenciais, projeto ECOMANAGE, avaliação, potencialidades, fragilidades. 


\section{Abstract}

The present work intends to promote the debate about coastal management in Brazil by analyzing the implementation of a local project of integrated coastal management - the Ecomanage project, that is being developed in the Santos - Sao Vicente estuarine system, SP, Brazil, (in its final phase), which main goals are to provide effective and practical management tools to assist in decision-making. Integrated coastal management is the actual paradigm in coastal management and its principles have been incorporated to Brazil's National Coastal Management Programme. Being an iterative process that redefines itself as it is developed and practice is acquired, evaluation of its main difficulties and opportunities is essential to guide its procedures in order to achieve its main objective, the sustainable development of coastal zones. The evaluation made to project Ecomanage showed that there were important political, institutional, technical and socio-cultural obstacles to it's implementation and that these were at a large extent similar to those that have been identified in coastal management practiced in Brazil and in the world. Nevertheless, important cooperation relationships with local parties could still be established and partnerships developed with governmental actors. These achievements have made it possible to carry on the work initiated by the Ecomanage project in the region.

Key-words: coastal zone, integrated coastal management, Santos - Sao Vicente Estuarine System, public participation, management tools, Ecomanage project, evaluation, potentialities, fragilities. 


\section{ÍNDICE DE TABELAS}

Tabela 1 - Magnitude dos principais bens e serviços por tipo de ecossistema sistema costeiro.

Tabela 2 - Resumo do grau de modificação dos habitats costeiros mundiais

Tabela 3 - Principais pressões sobre os ecossistemas e habitats costeiros e zonas adjacentes.

Tabela 4 - Evolução da Gestão Costeira...............................................................33

Tabela 5 - Vantagens e desvantagens da participação pública nos processos de tomada de decisão governamentais

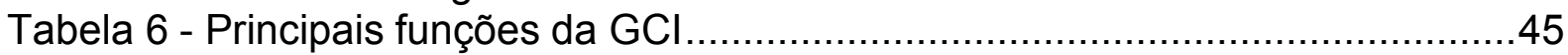

Tabela 7 - Ações prioritárias associadas a etapas do ciclo de GCl.........................46

Tabela 8 - Principais ações e resultados do MMA no âmbito do GERCO..................58

Tabela 9 - Resumo dos resultados obtidos pelos 17 estados costeiros brasileiros no

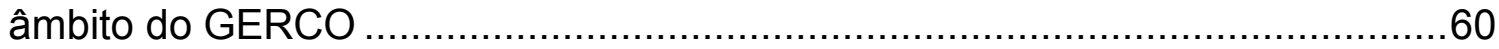




\section{ÍNDICE DE FIGURAS}

Figura 1 - Resumo das condições dos principais serviços ecossistêmicos mundiais...

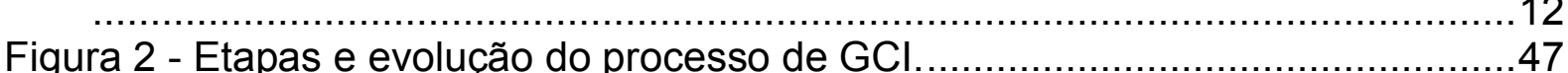

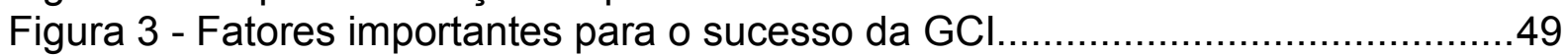

Figura 4 - Evolução do PNGC de acordo com o ciclo de GCl..............................67

Figura 5 - O Modelo DPSIR. ...................................................................

Figura 6 - Densidade populacional nas áreas pertencentes a bacia do estuário de

Santos - São Vicente a partir dos dados do IBGE, 2000 ...............................77

Figura 7 - Distribuição espacial de sub-moradias, em amarelo, na Baixada Santista

Figura 8 - Avanço das sub-moradias em áreas de manguezais .............................79 


\section{LISTA DE SIGLAS}

AGEM - Agência Metropolitana da Baixada Santista

BNDES - Banco Nacional de Desenvolvimento Econômico e Social

CETEC/CETAM - Centro Tecnológico de Lins - SP / Centro Técnico de Engenharia Ambiental

CETESB - Companhia de Tecnologia de Saneamento Ambiental do Estado de São Paulo

CIESIN - Center for International Earth Science Information Network

CIRM - Comissão Interministerial para os Recursos do Mar

CMMAD - Comissão Mundial do Meio Ambiente e Desenvolvimento

CNRH - Conselho Nacional dos Recursos Hídricos

CNUMAD - Conferência das Nações Unidas sobre o Meio Ambiente e Desenvolvimento

CODESP - Companhia Docas do Estado de São Paulo

COGERCO - Grupo de Coordenação do Gerenciamento Costeiro

COMDEMA - Conselho Municipal de Meio Ambiente

CONAMA - Conselho Nacional do Meio Ambiente

CONDESB - Conselho de Desenvolvimento da Região Metropolitana da Baixada Santista

CTCOST - Câmara Técnica de Integração da Gestão das Bacias Hidrográficas e dos Sistemas Estuarinos e Zonas Costeiras

DPSIR - Drivers, Pressures, State, Impact, Response Model

DSS - Decision Support System

EC - European Commission

ECOMANAGE - Integrated Ecological Coastal Zone Management System

EEA - European Environment Agency

EMBRAPORT - Empresa Brasileira de Terminais Portuários

ENCOGERCO - Encontro Nacional de Gerenciamento Costeiro

FAO - Food and Agriculture Organization of the United Nations

$\mathrm{GCl}$ - Gerenciamento Costeiro Integrado

GERCO - Programa Nacional de Gerenciamento Costeiro

GI-GERCO - Grupo de Integração do Gerenciamento Costeiro

GPA - Global Programme of Action for the Protection of the Marine Environment from Land-Based Activities

IBAMA - Instituto Brasileiro do Meio Ambiente e dos Recursos Naturais Renováveis.

IBGE - Instituto Brasileiro de Geografia e Estatística 
IGBP - International Geosphere-Biosphere Programme

IPCC - Intergovernmental Panel on Climate Change

JBIC - Japan Bank for International Cooperation

MEA - Millennium Ecosystem Assessment

MMA - Ministério do Meio Ambiente

OECD - Organization for Economic Cooperation and Development

ONG - Organização não Governamental

ONU - Organização das Nações Unidas

OSCIP - Organização da Sociedade Civil de Interesse Público

PAC - Plano de Aceleração do Crescimento

PAF - Planos de Ação Federal

PEGC - Plano Estadual de Gerenciamento Costeiro

PGZC - Plano de Gestão da Zona Costeira

PMGC - Plano Municipal de Gerenciamento Costeiro

PNGC - Plano Nacional de Gerenciamento Costeiro

PNMA - Política Nacional de Meio Ambiente

PNRM - Política Nacional para os Recursos do Mar

PRIMAHD - Programa Regional de Identificação e Monitoramento de Áreas de Habitação Desconforme

RQA-ZC - Relatório de Qualidade Ambiental da Zona Costeira

RMBS - Região Metropolitana da Baixada Santista

SABESP - Companhia de Saneamento Básico do Estado de São Paulo

SECIRM - Secretaria da Comissão Interministerial para Recursos do Mar

SIGERCO - Sistema de Informações do Gerenciamento Costeiro

SMA-ZC - Sistema de Monitoramento Ambiental da Zona Costeira

SQA - Secretaria de Qualidade Ambiental

UN - United Nations

UNEP - United Nations Environment Programme

UNESCO - Organização das Nações Unidas para a Ciência e a Cultura

WRI - World Resources Institute

ZEEC - Zoneamento Ecológico Econômico Costeiro 


\section{Introdução}

Hoje em dia, é possível afirmar que existe uma clara dependência entre a sobrevivência do Homem e a integridade dos ecossistemas. De acordo com o relatório do World Resources Institute (WRI, 2000), as economias mundiais atuais são de tal modo baseadas nos bens e serviços derivados desses ecossistemas que a própria vida humana está condicionada pela capacidade que estes têm de continuar a oferecer estes benefícios. No entanto, as prioridades de desenvolvimento das nações sempre estiveram focadas no quanto poderia ser extraído dos ecossistemas, deixando para segundo plano os impactos causados durante esse processo.

Conforme constatado no Millennium Ecosystem Assessment ${ }^{1}$ (MEA, 2005a), o resultado desse modelo, verificou-se que a escala das pressões humanas sobre os ecossistemas aumentou dramaticamente no último século e em particular nos últimos 50 anos, período durante o qual aconteceu a mais rápida e extensa mudança dos ecossistemas mundiais quando comparado com qualquer outro período na história da humanidade.

Estas mudanças foram causadas em grande parte pela necessidade de suprir as crescentes demandas por alimento, água, madeira, fibras e combustível, em função do aumento sem precedentes da população mundial, da forte expansão da economia global e do alcance obtido pelos avanços tecnológicos (MEA, 2005a). No entanto, a verdadeira causa que se esconde por detrás destes fatores e que os alimenta, corresponde aos atuais padrões de consumo da população mundial, sendo que o aumento do consumo há muito que ultrapassou o crescimento da população (WRI, 2000).

Constata-se, assim, que atualmente todos os ecossistemas da Terra são afetados pela ação humana, ao ponto de não ser mais possível estudar a maioria dos seus aspectos estruturais e funcionais sem considerar esta presença forte e freqüentemente dominante da humanidade. Conforme Vitousek et al (1997) as pressões antropogênicas são de várias ordens e resultam de atividades como por

\footnotetext{
${ }^{1}$ O Millennium Ecosystem Assessment foi um estudo realizado entre 2001 e 2005 sob os auspícios das Nações Unidas, com o objetivo de avaliar o estado dos ecossistemas mundiais, a sua capacidade real de fornecer serviços e os impactos das alterações observadas no bem-estar humano.
} 
ex. a agricultura, a indústria e o comércio, que estão transformando a terra e destruindo ou degradando habitats críticos, alterando os ciclos biogeoquímicos e adicionando ou removendo espécies da maioria dos ecossistemas mundiais. Até mesmo os oceanos com a sua imensidão estão demonstrando serem incapazes de suportar estas pressões, dando já sinais de graves impactos como conseqüência de problemas como a sobre-pesca, derrames, disposição de resíduos no oceano, contaminação de origem terrestre e destruição dos ecossistemas costeiros (Costanza et al, 1998).

Embora os benefícios obtidos até hoje do uso e exploração dos ecossistemas tenham sido substanciais para o bem-estar humano e para o desenvolvimento das nações, estes foram conseguidos através da degradação de vários serviços ecossistêmicos, do aumento do risco de mudanças não-lineares dos ecossistemas, do aumento da pobreza e do agravamento da desigualdade social para muitas populações (MEA, 2005a).

Estudos recentes feitos por agências internacionais mostram que a capacidade dos ecossistemas de oferecer bens e serviços, tomada como uma medida do seu estado atual, está em declínio devido à magnitude dos impactos causados pelos padrões atuais de exploração (WRI, 2000). Cerca de 60\% dos serviços ecossistêmicos mundiais encontram-se degradados ou estão sendo explorados insustentavelmente (MEA, 2005a).

Como agravante, a maioria destas alterações está, por sua vez, causando mudanças no próprio funcionamento do sistema Terra, cujas evidências mais notórias e incontroversas (IGBP, 2001) são as mudanças globais que estão ocorrendo, como as alterações climáticas e a perda irreversível de biodiversidade (Vitousek et al, 1997). Este quadro é exacerbado pelas previsões que demonstram que estas pressões continuarão a aumentar durante os próximos 50 anos (MEA, 2005a).

Outro fato verificado é que esta degradação dos ecossistemas raramente poderá ser revertida sem ações dirigidas não só às forças diretas, mas também às forças indiretas (fatores socioeconômicos, políticos, culturais etc.) que determinam o nível de produção e consumo dos serviços ecossistêmicos, o que torna qualquer tentativa para lidar com esta realidade um processo altamente complexo (MEA, 2005a). 
Assim, um conjunto efetivo de respostas que garanta a gestão sustentável dos ecossistemas terá de levar em conta todas estas forças e ter uma abordagem ecossistêmica, onde as decisões serão tomadas com base na avaliação integrada do ecossistema e não apenas centrada no Homem (UNEP, 2002).

No entanto, apesar da dependência dos ecossistemas ser óbvia e de haverem evidências da crescente vulnerabilidade do Homem face às mudanças ambientais, a tarefa de integrar considerações sobre a capacidade dos ecossistemas em decisões relacionadas com o desenvolvimento ainda permanece um desafio. Para tal, são requeridas mudanças institucionais e comportamentais profundas por parte da sociedade, que embora já esteja mais consciente da gravidade da situação, ainda não conseguiu reagir de maneira concertada e em tempo hábil para travar e reverter esta tendência (MEA, 2005a).

Este panorama traçado para a situação atual dos ecossistemas mundiais é particularmente grave para as zonas costeiras, pois são zonas que estão sob grande pressão devido aos padrões atuais de desenvolvimento mundial, que colocaram os ecossistemas costeiros entre os mais ameaçados do mundo (UNEP, 2006).

Os ecossistemas costeiros são zonas de alta produtividade primária com geralmente boa acessibilidade e como tal, sempre foram centros preferenciais de ocupação do Homem, que desde cedo se apercebeu da imensa potencialidade de exploração que estes sistemas ofereciam. Além de serem focos de biodiversidade e fonte de recursos naturais consideráveis, devido à diversidade de habitats e condições ali existentes, eles atuam igualmente como reservatórios de nutrientes, filtros para a poluição originada em terra e protegem as linhas de costa de erosão e tempestades, entre outros serviços (Burke et al, 2001).

Os ecossistemas costeiros fornecem, portanto, uma grande variedade de bens e serviços que, aliados a uma beleza natural única, transformam as zonas costeiras em atratores para a população mundial, tanto para habitação permanente como para turismo (Burke et al, 2001).

Apesar da grande riqueza e variedade de processos existentes nos ambientes costeiros e da sua conseqüente importância para o Homem, a sobrevivência destes sistemas depende de um equilíbrio natural entre os processos continentais e oceânicos, que se encontra cada vez mais comprometida pelas pressões originadas pelas populações costeiras e das zonas continentais adjacentes. 
Estas pressões, em conjunto com os efeitos causados pelas mudanças globais, têm se tornado de tal maneira importantes e impactantes, que a integridade de vários ecossistemas costeiros e manutenção dos seus serviços encontra-se ameaçada de ruptura.

A subsistência dos ecossistemas costeiros depende por isso cada vez mais da tomada de consciência da sociedade dos problemas existentes, assim como do desenvolvimento de estratégias que promovam um uso sustentável destas zonas, tão essenciais para o bem-estar do Homem e para a manutenção dos sistemas globais de suporte à vida.

Como tal, nas últimas décadas verificou-se ser necessária uma nova abordagem para o gerenciamento costeiro, onde os diferentes setores econômicos (como a pesca, a agricultura, o turismo e o ordenamento do território) fossem integrados e onde o público afetado tivesse uma maior participação e envolvimento na tomada de decisão, de maneira a construir um processo integrado de planejamento e gestão que contemplasse as necessidades tanto para o desenvolvimento como para a conservação (Olsen, 2003).

A Gestão Costeira Integrada surgiu, assim, como uma resposta a este desafio e tem sido desenvolvida e implementada nos últimos 40 anos ao redor do mundo, com maior ou menor intensidade, em função das características principalmente políticas e econômicas das diferentes nações, e com resultados bem diferentes, consoante as condições sócio-culturais e biofísicas locais (Olsen, 2003).

O principal objetivo deste trabalho é de contribuir para a análise do processo de gestão costeira no Brasil, ao acompanhar e analisar a implementação de um projeto local de gestão costeira integrada, de maneira a identificar, por um lado, os obstáculos que ainda existem para a concretização este tipo de projeto no país e, por outro, os avanços obtidos durante o processo, considerando-os como oportunidades e lições para o desenvolvimento de projetos futuros.

Pretende-se igualmente, como objetivo secundário, situar o desenvolvimento do presente projeto no contexto da evolução do processo de gestão costeira mundial e nacional, de maneira a verificar que respostas têm sido desenvolvidas para promover o uso sustentável das zonas costeiras, quais as dificuldades e oportunidades encontradas ao longo deste processo e por último, identificar quais os fatores que a prática tem demonstrado serem determinantes para se atingir esse propósito. 
Para tal, pretende-se, num primeiro momento, apresentar uma síntese da situação atual das zonas costeiras mundiais e das causas dos problemas ambientais existentes, assim como das tendências apontadas para um futuro próximo, através da literatura pertinente.

Num segundo momento, o cenário retratado anteriormente será contrastado com a história e a evolução do escopo da gestão costeira, objetivando entender a importância e relevância do surgimento do processo de gestão costeira integrada como resposta aos problemas descritos. O propósito e procedimentos da gestão costeira integrada serão igualmente caracterizados, para então se realizar uma análise crítica deste processo através da análise de relatos de experiências de projetos desta natureza desenvolvidos ao redor do mundo, de maneira a identificar as principais dificuldades que têm surgido ao longo da história da sua implementação.

Por último, tenta-se fazer um retrato do desenvolvimento e da situação atual da gestão costeira no Brasil quanto às suas concretizações e seus problemas, para depois, após uma breve apresentação de um projeto que pretende ser instrumento de gestão integrada, o projeto Ecomanage, descrever as principais dificuldades e oportunidades encontradas durante a sua implementação na Baixada Santista/SP, analisando-as frente ao que foi levantado na ainda escassa literatura existente sobre a gestão costeira no país. A avaliação destes aspectos foi possível pela oportunidade de acompanhar e participar diretamente dos trabalhos da equipe do projeto.

\section{Problemática das Zonas Costeiras}

\subsection{Definição de Zonas Costeiras}

As zonas costeiras correspondem à área de transição entre o continente e o oceano, muitas vezes estendendo-se desde as bacias hidrográficas até à plataforma continental e contêm por isso uma grande variedade de ambientes e ecossistemas (World Bank, 1996; Crossland \& Kremer, 2001). 
Estas áreas são formadas por um conjunto de sistemas dinâmicos e interligados que apresenta diversas formas e funções, o que dificulta muito a definição de limites geográficos precisos (FAO, 1998). A plasticidade destes limites pode ser verificada em trabalhos que foram elaborados em escala regional e global onde estas zonas foram definidas tanto como a área que se estende $100 \mathrm{~km}$ para dentro da linha de costa até uma profundidade de $200 \mathrm{~m}$ (Burke et al, 2001; WRI, 2000), a área compreendida entre $200 \mathrm{~m}$ de altitude e $200 \mathrm{~m}$ de profundidade (Pernetta \& Milliman, 1995 apud Crossland \& Kremer, 2001), ou então a área compreendida entre $50 \mathrm{~m}$ de altitude ou $100 \mathrm{~km}$ para dentro da linha de costa (o que for mais perto da costa) e 50 m de profundidade (MEA, 2005b).

A indefinição existente à volta deste conceito é agravada pelo fato dos limites geográficos das zonas costeiras, ou seja, os limites naturais, geralmente não corresponderem aos limites legais estabelecidos pelas legislações de cada país para efeitos de gestão. É por isso comum adotar-se a abordagem do grupo de trabalho para o Ambiente da OECD (Organization for Economic Cooperation and Development) que sugere que os limites destas zonas devem ser delineados consoante o problema ou os objetivos específicos de gestão (Crossland \& Kremer, 2001).

\subsection{A Importância das Zonas Costeiras}

\subsubsection{O Papel Ecológico}

As zonas costeiras são regiões altamente dinâmicas devido à transferência de energia e matéria que ocorre entre os sistemas terrestre e marinho, resultante de forças naturais, como as marés e o clima (FAO, 1998). Os fluxos de nutrientes de que se beneficiam, tanto de origem terrestre (trazidos pela chuva e pelos rios) quanto de origem marinha, fazem destas zonas áreas de alta produtividade biológica, que chegam a totalizar cerca de $25 \%$ da produtividade primária global (Agardy \& Alder, 2005), dando assim origem a importantes habitats terrestres e aquáticos (FAO, 1998; Jickells, 1998).

O conjunto destes habitats forma ecossistemas costeiros únicos como recifes de corais, estuários, marismas, florestas de manguezais, kelps e outras zonas 
úmidas que, ao servirem igualmente de áreas de berçário e de alimentação para várias espécies de animais, transformam estes ecossistemas em enormes centros de biodiversidade (FAO, 1998).

Por outro lado, os ecossistemas costeiros têm também um papel fundamental na proteção da linha de costa. As suas características físicas e mesmo os componentes biológicos ajudam a mitigar os efeitos de desastres naturais como tempestades, cheias ou o recuo da linha de costa, sendo igualmente essenciais em processos naturais como a acreção de sedimento ou no controle da erosão causada pela ação das ondas e dos ventos (FAO, 1998).

\subsubsection{A Importância Socioeconômica}

As condições biofísicas das zonas costeiras, juntamente com o fato de terem uma localização estratégica para efeitos de comunicação e transporte, tornaram desde cedo estas regiões em focos preferenciais para ocupação humana. Esta grande atratividade resulta do fato das zonas costeiras proverem um número considerável de recursos, produtos e serviços cruciais para as necessidades sociais e econômicas da população mundial.

A Tabela 1 mostra bem a importância socioeconômica dos ecossistemas costeiros, pois permite avaliar a contribuição que cada tipo de ecossistema tem, em termos de fornecimento de serviços ${ }^{2}$. Esta abordagem, onde os ecossistemas são avaliados com base nos serviços que conseguem oferecer, é cada vez mais utilizada pois é considerada uma maneira clara de explicitar a ligação entre a capacidade biológica dos ecossistemas e o bem-estar humano. Permite também ter uma perspectiva humana do estado dos ecossistemas, o que é fundamental para a sua gestão, uma vez que o Homem é indubitavelmente a fonte primária de pressões, tendo o impacto das suas ações há muito ultrapassado o efeito das mudanças induzidas por processos naturais (WRI, 2000).

\footnotetext{
2 Os serviços ecossistêmicos correspondem aos benefícios que as pessoas obtêm dos ecossistemas. Estes são divididos em serviços de aprovisionamento (por ex. comida, água, combustível), serviços de regulação (por ex. do clima, doenças, água), serviços de suporte (por ex. formação de solo, ciclo de nutrientes) e serviços culturais (por ex. recreação, educação, espiritual) (MEA, 2005a).
} 


\begin{tabular}{|c|c|c|c|c|c|c|c|c|}
\hline $\begin{array}{l}\text { Serviços Diretos e } \\
\text { Indiretos }\end{array}$ & $\begin{array}{l}\text { Estuários e } \\
\text { Marismas }\end{array}$ & Manguezais & $\begin{array}{l}\text { Lagoas e } \\
\text { Lagunas }\end{array}$ & Interdital & Kelp & $\begin{array}{l}\text { Recifes de } \\
\text { Rocha e } \\
\text { Conchas }\end{array}$ & $\begin{array}{l}\text { Prados } \\
\text { Fanerógamas } \\
\text { Marinhas }\end{array}$ & $\begin{array}{l}\text { Recifes } \\
\text { de Coral }\end{array}$ \\
\hline Comida & - & - & - & - & - & - & - & - \\
\hline Fibras/Madeira/Combustivel & - & & - & & & & & \\
\hline Medicamentos & - & $\bullet$ & - & & - & & & - \\
\hline Biodiversidade & - & $C$ & - & C & - & O & - & 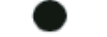 \\
\hline Regulaçāo Biológica & - & & - & - & & - & & - \\
\hline $\begin{array}{l}\text { Retenção e Armazenamento } \\
\text { Água Doce }\end{array}$ & • & & $\bullet$ & & & & & \\
\hline Bioquímicos & - & - & & & - & & & - \\
\hline Ciclagem Nutrientes/Fertilização & - & - & - & - & - & - & & - \\
\hline Hidrológicos & • & & • & & & & & \\
\hline $\begin{array}{l}\text { Regulação atmosférica e } \\
\text { climática }\end{array}$ & & - & - & - & & - & - & - \\
\hline Controle doenças humanas & - & - & - & - & & - & - & - \\
\hline Processamento Poluição & & & - & & & - & - & - \\
\hline Proteçăo Enchentes & • & - & - & - & - & - & - & 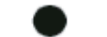 \\
\hline Controle Erosão & • & & • & & & & - & - \\
\hline Culturais & & - & - & 0 & - & - & - & 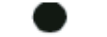 \\
\hline Recreação & & $\bullet$ & • & O & - & & & 0 \\
\hline Estéticos & & $\bullet$ & - & 9 & & & & \\
\hline
\end{tabular}

Tabela 1 - Magnitude dos principais bens e serviços por tipo de ecossistema sistema costeiro. Os círculos maiores representam maior magnitude (Modificado de Agardy \& Alder, 2005).

A existência de uma grande diversidade de recursos naturais tais como minerais, óleos e materiais de construção (areia, rocha, coral, cal e madeira), assim como solos férteis e águas ricas em nutrientes, possibilita a existência de várias atividades econômicas fundamentais. Assim, atividades como agricultura, pesca e aqüicultura coexistem com atividades portuárias, vários tipos de indústria e turismo transformando as zonas costeiras em grandes centros econômicos (Agardy \& Alder, 2005; FAO, 1998; Von Bodungen \& Turner, 2001).

A pesca e o turismo são das atividades que mais atenção têm recebido pois estão entre as que mais ameaçam os ecossistemas costeiros devido às proporções que atingiram e às práticas associadas. Além do mais, são também de particular importância para os países em desenvolvimento, uma vez que as suas economias são fortemente dependentes dos rendimentos resultantes destas atividades, além destas serem geralmente uma atividade de subsídio das suas populações (Turner et al, 1996; WRI, 2000; UNEP, 2006).

Relativamente à pesca, é fácil entender a sua importância socioeconômica quando se verifica que a maioria das capturas pesqueiras mundiais (90\% a 95\%) ocorre em águas da plataforma continental, o que corresponde de $5 \%$ a $10 \%$ da produção mundial de alimento, e dessas capturas, a maior parte é apanhada até 
uma distância de $9 \mathrm{~km}$ da costa (Turner et al, 1996). A pesca e atividades associadas provêem igualmente emprego direto para cerca de 38 milhões de pessoas (FAO, 2004 apud UNEP, 2006). Por outro lado, peixe e marisco são também fontes importantes de proteína, sobretudo para os países em desenvolvimento, onde o peixe chega a representar a única fonte de proteína para cerca de 1/6 da população mundial (UNEP, 2006).

Quanto ao turismo, este é atualmente a maior indústria do mundo e o setor econômico de maior crescimento em escala global (WRI, 2000). De fato, o turismo costeiro representa para a maioria dos países o maior setor desta indústria, sendo que, em outros (sobretudo pequenos estados de ilhas em desenvolvimento), este contribui significativamente para o seu PIB. Assim, um dos serviços culturais mais importantes oferecidos pelos ecossistemas costeiros e marinhos é o turismo (e recreação associada) (WRI, 2000; UNEP, 2006).

Embora seja difícil aferir um valor econômico aos ecossistemas costeiros devido, sobretudo, ao fato de que muitas das suas funções e serviços não têm um preço no mercado (como por ex. valores estéticos ou o valor intrínseco da conservação de uma espécie ou sistema) (Turner et al, 1996), a valoração do uso dos recursos e dos serviços ambientais das zonas costeiras tem sido alvo de vários estudos científicos na última década.

Como exemplo, tem-se um estudo de Costanza et al. (1997) que fez uma estimativa do valor dos bens e serviços ecossistêmicos mundiais e atribuiu um valor de $24 \$$ trilhões de dólares por ano às zonas costeiras, enquanto que o produto global bruto é de $18 \$$ trilhões de dólares por ano.

Portanto, apesar de ainda existirem várias fragilidades e dúvidas neste tipo de avaliação, tem ficado claro que o valor global das zonas costeiras é bastante significativo (Crossland \& Kremer, 2001).

Os ecossistemas costeiros são, portanto, sistemas complexos onde ocorrem ciclos biogeoquímicos fundamentais que sustentam uma grande produtividade primária e são por isso de uma importância ecológica extrema. Por outro lado, os ecossistemas costeiros fornecem igualmente um número considerável de bens e serviços de valor considerável para as sociedades humanas. No entanto, esta exploração (direta ou indireta) por parte do Homem tem-se traduzido num aumento insustentável de pressões e impactos, modificando os padrões naturais e a qualidade do ambiente destas zonas. 


\subsection{Estado das Zonas Costeiras e Causas da Degradação Ambiental}

\subsubsection{Situação Atual das Zonas Costeiras}

Existem cada vez mais provas que retratam uma evidente e crescente degradação dos ecossistemas costeiros mundiais, colocando-os atualmente entre os mais ameaçados do mundo (GESAMP, 2001; WRI, 2000; Agardy \& Alder, 2005).

Conclusões do Millennium Ecosystem Assessment - MEA (2005), mostram que a sobrepesca, os métodos destrutivos de pesca, e a poluição, entre outros impactos humanos, resultaram na alteração ou mesmo destruição dos habitats costeiros mundiais.

Já em 2001, altura em que se concluía o primeiro levantamento ${ }^{3}$ das condições dos cinco principais tipos de ecossistemas do mundo (e cujos resultados serviram de base para a realização do MEA), constatou-se que, da totalidade da área ocupada pelas zonas costeiras, cerca de $29 \%$ já se encontravam alteradas ou semi-alteradas e que, apesar das restantes $71 \%$ ainda estarem pouco alteradas, grande parte destas correspondiam a áreas não ocupadas nas latitudes extremas, não sendo este valor, portanto, muito significativo (Burke et al, 2001).

Por altura das conclusões do MEA, verificou-se que muito embora existam grandes lacunas de dados, essas alterações traduziram-se na conversão ou mesmo na perda de partes substanciais de ecossistemas costeiros, como é possível verificar na Tabela 2.

Essas alterações afetam obviamente o funcionamento e os processos inerentes aos ecossistemas, o que por sua vez, altera a sua produtividade e a sua capacidade de continuar a providenciar bens e serviços. Este cenário ficou bem claro num estudo feito pelo World Resources Institute - WRI (2000), que avaliou a situação destes ecossistemas levando em consideração a sua atual capacidade de fornecer bens e serviços ecossistêmicos chave quando comparados com a situação de 30 anos atrás (WRI, 2000).

\footnotetext{
${ }^{3}$ Pilot Analysis of Global Ecosystems - Estudo realizado pelo World Resources Institute em 2001.
} 


\begin{tabular}{|c|c|c|}
\hline TIPO DE HABITAT & ESTADO & COMENTÁRIOS \\
\hline Estuários & Perdas substanciais & $\begin{array}{l}\text { Ex: }<10 \% \text { de zonas úmidas naturais nas } \\
\text { costas da Califórnia e mais de metade das } \\
\text { costas dos Estados Unidos } \\
\text { substancialmente alteradas. }\end{array}$ \\
\hline Manguezais & $\begin{array}{l}35 \% \text { perda em } 2 \text { décadas em países com } \\
\text { dados disponíveis. }\end{array}$ & $>80 \%$ perda em alguns países \\
\hline Recifes de Coral & $\begin{array}{l}20 \% \text { gravemente danificados e com pouca } \\
\text { probabilidade de recuperação (estimativa } \\
\text { de } 2004 \text { ); } 70 \% \text { destruídos, em estado } \\
\text { crítico ou ameaçados (estimativa de } 2004 \text { ) }\end{array}$ & $\begin{array}{l}\text { O Caribe e o Sudeste Asiático são as } \\
\text { zonas mais degradas. }\end{array}$ \\
\hline Habitats Interditais e Deltas & Degradação substancial & $\begin{array}{l}37 \% \text { perdas na costa do Mar Amarelo da } \\
\text { China desde } 1950 ; \\
43 \% \text { perdas na Coréia do Sul desde } 1918 \text {. }\end{array}$ \\
\hline Praias e Dunas & $\begin{array}{l}\text { Perda total ou degradação em inúmeros } \\
\text { lugares. }\end{array}$ & \\
\hline Prados de Fanerógamas & $\begin{array}{l}\text { Grandes perdas no Mediterrâneo, Florida e } \\
\text { Austrália }\end{array}$ & $\begin{array}{l}\text { Espera-se uma aceleração da degradação, } \\
\text { sobretudo no Sudeste Asiático e no } \\
\text { Caribe. }\end{array}$ \\
\hline Florestas de Kelp & $\begin{array}{l}\text { Praticamente nenhuma existente em } \\
\text { condições naturais. }\end{array}$ & \\
\hline Marismas & Alterações massivas e perdas. & \\
\hline Mares Semi-fechados & Ficando altamente degradados & \\
\hline Outras Comunidades Bentônicas & $\begin{array}{l}\text { Gravemente impactadas devido aos efeitos } \\
\text { da pesca. }\end{array}$ & $\begin{array}{l}\text { Fortes evidências de impactos nas funções } \\
\text { ecossistêmicas e resiliência. }\end{array}$ \\
\hline
\end{tabular}

Tabela 2 - Resumo do grau de modificação dos habitats costeiros mundiais (Adaptado de UNEP, 2006)

Observou-se, então, que todos os bens e serviços avaliados estavam numa condição medíocre ou pobre. Em termos de produção de alimento, verificou-se que a produção mundial de peixe aumentou seis vezes desde 1950, mas que a maioria das capturas passou a ser de espécies com baixo valor comercial ou provenientes de aqüicultura, uma vez que a disponibilidade de espécies de alto-valor comercial diminuiu consideravelmente devido à sua sobre-exploração. A situação é de tal maneira grave que se estimou que cerca de $75 \%$ das pescarias principais estão esgotadas ou sobre-capturadas, num momento em que as frotas de barcos têm cada vez mais capacidade para pescar além do máximo de sustentabilidade dos estoques.

Quanto à qualidade da água, esta diminuiu consideravelmente, ocorrendo cada vez mais florações de algas tóxicas e episódios de hipóxia, indicando que alguns ecossistemas costeiros excederam a sua capacidade de absorver nutrientes e outros poluentes face às quantidades recebidas. Isto se deve também, em parte, à destruição de importantes zonas úmidas costeiras.

Relativamente à biodiversidade, indicadores como a perda de habitat, incidência de novas doenças, evolução de espécies invasoras e taxas de branqueamento de corais apontam todos para um importante declínio. Vários 
ecossistemas costeiros estão sofrendo assoreamentos devido aos sedimentos e poluição vindos de terra e práticas destrutivas de pesca, como o arrasto, são fortes contribuintes para este declínio.

Por último, verificou-se que as modificações feitas pelo Homem na linha de costa alteraram de tal maneira o balanço sedimentar litoral que o seu equilíbrio encontra-se fortemente perturbado, o que se torna ainda mais preocupante quando considerado em conjunto com as conseqüências das mudanças climáticas esperadas.

Estas conclusões bastante significativas demonstram que nem o panorama atual, nem as previsões para um futuro próximo são particularmente sorridentes para os ecossistemas costeiros, o que, aliás, não difere muito do restante dos ecossistemas mundiais, como é possível observar na Figura 1.

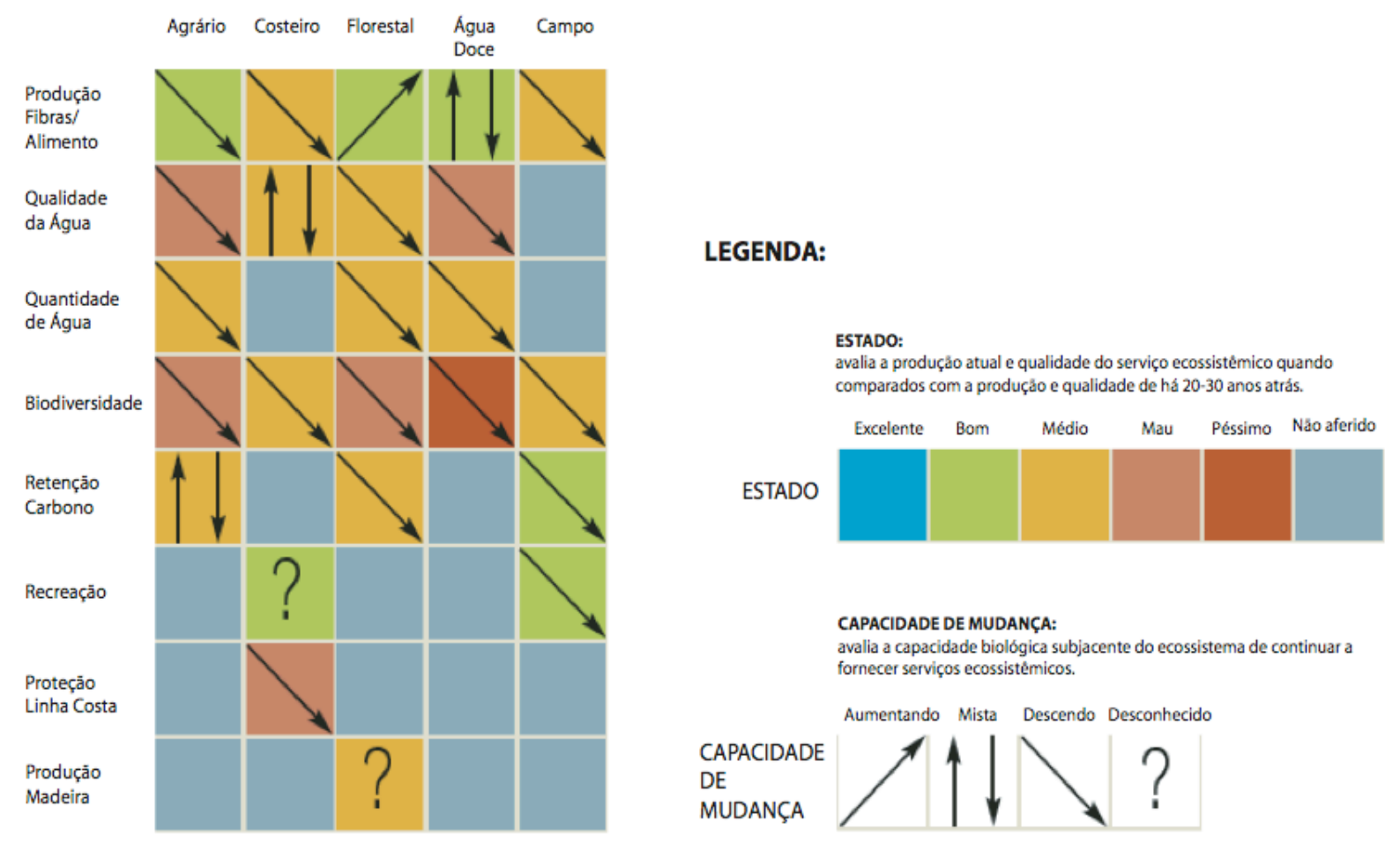

Figura 1 - Resumo das condições dos principais serviços ecossistêmicos mundiais (Modificado de WRI, 2000)

Verificou-se também no MEA, que apesar da exploração das zonas costeiras já existir há vários séculos, estas alterações intensificaram-se sobretudo nas últimas décadas. Como conseqüência, os sistemas costeiros têm cada vez mais dificuldade em acomodar a crescente procura coletiva de populações e mercados em expansão. 
Torna-se, assim, necessário e urgente entender quais as causas que levaram a este estado, o que é abordado em seguida.

\subsubsection{Forçantes de Mudança e Principais Pressões}

As razões subjacentes a este estado atual dos sistemas costeiros mundiais resultam por um lado, de fatores socioeconômicos e tecnológicos onde o Homem é o ator principal (forçantes humanas) e por outro, de forçantes naturais, onde o Homem tinha até há pouco tempo um papel insignificante, mas que devido à natureza e intensidade das suas ações, representa cada vez mais um papel principal.

\subsubsection{Forçantes humanas}

As principais causas apontadas para o nível atual de pressões que ocorrem nas zonas costeiras são o aumento da densidade da população costeira, a globalização, abertura dos mercados estrangeiros e avanços tecnológicos. É preciso notar que, apesar destes fatores já ocorrerem há bastante tempo, só recentemente é que estão tomando proporções demasiadamente grandes para que os sistemas naturais os consigam acompanhar e compensar as perturbações, como tinham geralmente conseguido fazer até então.

- Aumento da densidade da população costeira.

Um dos fatores mais relevantes causador de uma aceleração da degradação dos ecossistemas costeiros, está ligado à aglomeração de uma população mundial em crescimento nas zonas costeiras. Em 1990, tínhamos 1.96 bilhões de pessoas vivendo a menos de $100 \mathrm{~km}$ da linha de costa, enquanto que em 1995 esse número já tinha ascendido a 2.14 bilhões de pessoas. Ou seja, em 1995, 39\% da população mundial ocupava uma zona que representa apenas $20 \%$ da superfície terrestre (Small \& Nicholls 2003; CIESIN, 2003) e, embora não existam dados robustos mais recentes, sabe-se que essa tendência de crescimento tem se confirmado. (Small \& Nicholls, 2003, CIESIN, 2003; Burke et al, 2001). Por outro lado, estudos 
quantitativos recentes demonstram que atualmente existe uma diminuição da taxa de crescimento da população no interior dos continentes, quando comparada com a da população costeira (Agardy \& Alder, 2005).

Como as zonas costeiras representam uma superfície bem menor do que as áreas continentais interiores, este crescimento traduziu-se igualmente num aumento considerável da densidade populacional nestas regiões. Tendo em conta que a densidade populacional é considerada como um bom indicador do grau de modificação direta induzida pelo Homem nos sistemas costeiros (Burke et al, 2001), é possível ter uma noção das mudanças a que estão sendo sujeitas as zonas costeiras quando, por exemplo, em 2000, se verificou que este valor chegou a ser 3 vezes maior do que o de áreas interiores, de respectivamente $99.6 \mathrm{hab} / \mathrm{km}^{2}$ contra $37.9 \mathrm{hab} / \mathrm{km}^{2}$ (Agardy \& Alder, 2005).

Além da densidade populacional costeira ser bem maior do que a do interior, existe a agravante de essa distribuição não ser uniforme. De fato, a maioria da população costeira concentra-se ao redor dos ecossistemas mais produtivos e, conseqüentemente, mais valiosos sob o ponto de vista socioeconômico. Infelizmente, esses são também os de maior importância ecológica: $71 \%$ da população costeira vive a menos de $50 \mathrm{~km}$ de um estuário, $31 \%$ de um recife de coral, $45 \%$ de um manguezal e $49 \%$ de bancos de fanerógamas marinhas (Agardy \& Alder, 2005).

Por outro lado, cerca de $58 \%$ do principais recifes de coral mundiais ocorrem a menos de $25 \mathrm{~km}$ de centros urbanos com mais de 100000 pessoas, assim como $62 \%$ dos estuários e $64 \%$ dos manguezais. Isto significa que as pressões da urbanização, incluindo a conversão de habitat à qual se assiste à medida que as cidades e as respectivas áreas de influência crescem, afetam a maioria desses habitats costeiros chave (Agardy \& Alder, 2005).

Por último, é preciso constatar que a relação do aumento da densidade da população costeira com a diminuição da qualidade ambiental não é linear. Os impactos desse aumento estão intimamente ligados ao comportamento humano, que acaba sendo freqüentemente o fator determinante quanto ao uso do ambiente vir a ser feito de um modo sustentável ou não. Os padrões de consumo que, por exemplo, nos países industrializados são a principal forçante dos impactos nos ecossistemas costeiros, acabam por sê-lo igualmente nos países em 
desenvolvimento, pois os recursos para alimentar o consumismo dos primeiros são freqüentemente extraídos dos segundos.

- Globalização e mercados estrangeiros

Outro fator socioeconômico que influencia fortemente o atual uso das zonas costeiras é a globalização e a abertura dos mercados estrangeiros. A globalização, período pelo qual toda a nossa civilização está passando, está permitindo aos usuários costeiros uma maior mobilidade e também mais acesso a informação e outros tipos de recursos, expondo as zonas costeiras a um número cada vez maior de usuários, o que acaba por causar mais poluição nestas zonas, mais perdas de habitat e muitas vezes, perdas dos direitos das comunidades locais, levando-as à sua marginalização.

Por outro lado, o acesso aos mercados estrangeiros fez com que houvesse um aumento do número de consumidores e conseqüentemente na procura por bens e serviços. Isto fez com que as pressões nos recursos costeiros também tenham aumentado de acordo, o que está gerando, em muitos casos, a sua sobreexploração, assim como perdas de habitat.

Uma maior discussão sobre o impacto da globalização no meio-ambiente como um todo será apresentada mais à frente, pois a conscientização dos efeitos da globalização sobre o meio-ambiente mundial foi determinante para uma mudança de visão na gestão do ambiente e em particular das zonas costeiras.

\section{- Avanços tecnológicos}

Finalmente, a evolução da tecnologia tem possibilitado ao Homem avanços consideráveis na sua capacidade de alterar os ecossistemas costeiros ou a sua área de influência e também de conseguir explorar e muitas vezes sobre-explorar os recursos costeiros, ao permitir mais e melhor acesso a estes. Exemplos destes avanços são a construção de barragens e estruturas de proteção da linha de costa que ameaçam fortemente a integridade de várias zonas costeiras ou a intensificação do esforço de pesca, devido à utilização de radares e tecnologia GPS para detectar cardumes e que tem contribuído bastante para a sobre-exploração de vários estoques pesqueiros (UNEP, 2006). 


\subsubsection{Forçantes Naturais}

Como já foi comentado, a magnitude, a escala e o ritmo das mudanças induzidas pelo Homem no último século não têm precedentes na história da sua evolução. Por outro lado, as conseqüências destas alterações são de tal ordem graves que atualmente é fato incontestável que as atividades do Homem estão modificando processos naturais globais (apesar de haver ainda bastante incerteza quanto ao grau de gravidade), levando a Terra a operar num estado sem analogias (IGBP, 2001; IPCC, 2007).

Embora os efeitos desta interferência humana se repercutam no ambiente global, eles são mais intensos e visíveis ao nível das zonas costeiras, pois estas representam uma zona de interface entre o ar, a terra e o mar. Como conseqüência, as mudanças globais que estão acontecendo no sistema Terra, sejam climáticas, biofísicas ou humanas, estão colocando os já impactados ecossistemas costeiros sob maior pressão ainda, aumentando o risco de sua destruição e também das populações que neles habitam e deles dependem (Turner et al, 1996; Huppert \& Sparks, 2006).

Os fatores que mais ameaçam estes sistemas resultam das alterações climáticas e do aumento do nível médio do mar verificados nas últimas décadas. Embora ainda seja difícil atualmente distinguir entre impactos induzidos por mudanças climáticas ou por outras razões como processos naturais ou devido à interferência direta do Homem, o último estudo do IPCC (IPCC, 2007) relata que o aumento dos níveis de $\mathrm{CO} 2$ na atmosfera levaram a uma diminuição de 0.1 unidades no $\mathrm{pH}$ dos oceanos, que houve um aumento na intensidade de ciclones tropicais, que o nível médio do mar aumentou $1.7 \pm 0.5 \mathrm{~mm} /$ ano durante o séc. XX e que as temperaturas médias da superfície do mar subiram $0.6^{\circ} \mathrm{C}$ desde 1950.

Assim, apesar das incertezas, observou-se no mesmo estudo que as zonas costeiras ficaram mais suscetíveis a eventos extremos e tempestades e que os custos socioeconômicos resultantes para as sociedades costeiras foram elevados. A subida do nível médio do mar durante o século passado contribuiu igualmente para o aumento de inundações costeiras, de erosão e perda de habitats, embora com variações locais e regionais muito grandes. Finalmente, verificou-se também que o aquecimento global está provocando o degelo das calotas polares, assim como 
eventos cada vez mais freqüentes de branqueamento de corais ou mesmo mortalidade.

A dinâmica dos ecossistemas marinhos, sobretudo ao nível dos seus processos, estrutura e funcionamento, também tem sofrido alterações devido a mudanças nas interações oceano-atmosfera, como demonstra estudo realizado pelo IGBP (IGBP, 2003).

Como conclusão e apesar de ainda não ser possível quantificar ou prever com exatidão a magnitude dos efeitos que estas mudanças climáticas antropogênicas estão ou vão ter nos ecossistemas costeiros, sabe-se com grande nível de confiança que haverá um aumento dos riscos aos quais as costas estão expostas devido a estas mudanças e que estes serão exacerbados pela intensificação das pressões induzidas pelo Homem, pressões que serão analisadas em seguida (IPCC, 2007).

\subsubsection{Pressões e Impactos}

As forçantes acima descritas são as forças motrizes que estão por detrás das pressões resultantes das transformações físicas, biológicas e químicas que o Homem impôs aos sistemas costeiros. Estas pressões estão por sua vez impactando-os de tal maneira que o seu equilíbrio natural foi alterado, levando estes sistemas ao estado de degradação e destruição atual.

Apesar de existirem diferenças quanto à natureza e extensão das pressões sobre os ecossistemas costeiros, elas geralmente resultam de atividades antropogênicas com fraca regulamentação e cujo planejamento geralmente não consegue acompanhar o ritmo ao qual ocorre o seu desenvolvimento, tornando-o rapidamente obsoleto. Esta realidade é particularmente grave para os países em desenvolvimento, uma vez que o rápido crescimento da população é acompanhado por uma acentuação da pobreza, o que torna a resolução dos problemas cada vez mais difícil e urgente (GESAMP, 2001; UNEP, 2006).

Assim, apesar da situação atual dos habitats e recursos costeiros ser preocupante, estes continuam a ser usados para prover elementos básicos para a vida do Homem, tal como para o comércio e o lazer. As águas costeiras são usadas para a descarga de esgotos e de lixo. A pesca está cada vez mais destrutiva e os 
estoques sobrexplorados. As zonas costeiras estão sobre-desenvolvidas, os habitats progressivamente alterados e destruídos, e a intrusão, seja acidental ou não, de espécies alienígenas causando graves perturbações nos ecossistemas e conseqüentemente, nas economias (GESAMP, 2001; UNEP, 2006; Crossland \& Kremer, 2001).

Aos impactos originados por estas mudanças, soma-se a degradação crônica causada pela poluição de origem marinha e, sobretudo, terrestre, uma vez que segundo a última avaliação do estado do ambiente marinho feita pelas Nações Unidas (UNEP, 2006), cerca de $80 \%$ da poluição marinha vem do ambiente terrestre.

Aliás, muito embora estas pressões estejam sendo exercidas sobre os sistemas costeiros, a maioria dos problemas que afetam estas zonas advem principalmente dos sistemas terrestres. Isto acontece, pois apesar das atividades estarem se desenvolvendo nas bacias hidrográficas adjacentes, são as zonas costeiras e marinhas que acabam sendo os receptores finais das conseqüências negativas dessas atividades (GESAMP, 2001).

Assim, várias atividades que exploram ou que aproveitam as condições oferecidas pelos sistemas naturais existentes ao longo das bacias hidrográficas, estão diminuindo a qualidade das águas ao contaminá-las com agroquímicos e outros poluentes. A construção de barragens, assim como de outras alterações dos cursos de água naturais, estão também afetando o transporte sedimentar dos rios, aumentando tanto episódios de assoreamento como de erosão. As modificações de vários habitats estão diminuindo a biodiversidade dos ecossistemas (GESAMP, 2001; Crossland \& Kremer, 2001).

Pressões adicionais vindas dos sistemas marinhos representam, também, uma realidade que, junto com as alterações climáticas acima discutidas, poderão vir a intensificar ainda mais os impactos nos ecossistemas costeiros (IPCC, 2007).

Em seguida, apresenta-se a Tabela 3, que resume quais são atualmente as principais pressões existentes nos vários habitats e ecossistemas existentes nas zonas costeiras e adjacentes: 


\begin{tabular}{ll}
\hline \multicolumn{1}{c}{ Ecossistema Costeiro } & \multicolumn{1}{c}{ Pressões } \\
\hline \hline Recifes de Coral & $\begin{array}{l}\text { Eutrofização, Turbidez, Práticas destrutivas de } \\
\text { pesca, Sobre-Pesca, Colocação de minas nos } \\
\text { recifes, Mercado do aquarismo, Doenças. } \\
\text { Zsonas Húmidas } \\
\text { aterros. }\end{array}$ \\
Prados de Fanerogamas & $\begin{array}{l}\text { Siltação, Desenvolvimento costeiro, Eutrofização, } \\
\text { Distúrbios físicos. }\end{array}$ \\
Lagoas Costeiras & Uso do solo para desenvolvimento, Poluição \\
Manguezais & Sobre-exploração, Desmatamento para uso do \\
solo para desenvolvimento, Aqüicultura. & Desenvolvimento, Modificação de habitats, \\
Linha de Costa & Erosão. \\
Bacias Hidrográficas & $\begin{array}{l}\text { Desmatamento, Erosão do solo, Poluição, Perda } \\
\text { de Habitat. }\end{array}$ \\
Estuários & Redução fluxo de água, Poluição, Siltação. \\
Ilhas Pequenas & Alteração do nível do mar, Gestão dos resíduos, \\
Plataforma Continental & Poluição, Pesca, Dragagem, Navegação. \\
Mares Semi-fechados & Poluição, Desenvolvimento costeiro, Pesca. \\
\hline
\end{tabular}

Tabela 3 - Principais pressões sobre os ecossistemas e habitats costeiros e zonas adjacentes (Adaptado de GESAMP, 2001)

Posto isto, as conclusões de estudos recentes (GESAMP, 2001; WRI, 2000; Agardy \& Alder, 2005; UNEP, 2006) que analisaram o estado mundial das zonas costeiras são bastante concordantes ao apontar os principais impactos que assolam estas zonas como: 1) destruição e alteração de habitat, 2) eutrofização, 3) mudanças na hidrologia e no fluxo de sedimentos, 4) sobre-pesca, e 5) poluição.

Todavia, pode-se considerar que todos estes impactos derivam de dois principais problemas que afetam todas as zonas costeiras mundiais e que se resumem à conversão de habitats para efeitos de desenvolvimento costeiro e a certos tipos de uso dos recursos. São estes problemas que estão gerando perdas grandes, quando não totais, dos serviços ecossistêmicos e cuja evolução irá determinar o futuro das zonas costeiras (Agardy \& Alder, 2005).

\subsubsection{Tendências Previstas e Problemas Prioritários}


O estado atual das zonas costeiras é preocupante, assim como o são as previsões quanto à sua evolução. De acordo com o MEA, as pressões e impactos identificados tendem a continuar, quando não aumentar. A perda de habitat costeiro é um dos impactos que apresenta esta tendência e que será possivelmente acelerado, à medida que crescer a demanda por usos conflituosos como o espaço costeiro e os seus recursos. O fator que mais contribuirá para a destruição dos habitats continuará a ser o desenvolvimento costeiro, cujos efeitos serão potencializados pelas alterações climáticas, uma vez que a maioria das zonas mais vulneráveis (como atóis, deltas e planícies de inundação) já se encontra ocupada (Agardy \& Alder, 2005).

A sobre-exploração de vários recursos costeiros é outro fator apontado pelo MEA que se espera que vá aumentar. Este quadro é particularmente alarmante para a pesca, pois caso as tendências verificadas atualmente continuarem, muito dos estoques serão levados para níveis de extinção comercial e ecológica.

Haverá também, durante as próximas décadas, um grande aumento das taxas de eutrofização e prevalência de "zonas mortas", à medida que os níveis de nutrientes e resíduos crescerem e as águas oceânicas aquecerem. Espera-se, igualmente, que os níveis de poluentes continuem a aumentar, apesar de já existirem medidas de controle eficientes para certas substâncias (UNEP/GPA, 2006).

Por último, as conclusões do MEA indicam que as interferências antrópicas efetuadas no regime hidrológico e no fluxo de sedimentos (tanto fluvial, como costeiro) continuarão a produzir graves impactos nos ecossistemas costeiros.

Esta realidade é particularmente grave para o Homem, pois o seu bem-estar está fortemente dependente da possibilidade de uso e exploração destes serviços, uma vez que os ecossistemas costeiros estão na base da maioria dos componentes que Ihe permitem ter uma boa qualidade de vida (como por ex. fornecimento de alimento, abrigo, emprego, comercialização de recursos, valores culturais e estéticos e proteção contra eventos naturais). Estes fatos são ainda mais preocupantes quando se verifica que a dependência das zonas costeiras é cada vez maior (UNEP, 2006).

Não é, portanto, de admirar que uma das projeções feitas pelo MEA seja de que o bem-estar humano irá sofrer graves conseqüências, resultantes do cenário 
descrito, caso não sejam realizadas melhorias significativas na gestão costeira em várias regiões do mundo.

Assim, apesar de já terem sido concretizados importantes progressos na redução e minimização dos impactos causados pelas principais ameaças aos ambientes costeiros, o último relatório das Nações Unidas sobre o estado do ambiente marinho (UNEP/GPA, 2006) relata que ainda existe um longo caminho a percorrer.

As áreas prioritárias segundo este relatório são 1) o esgoto e a gestão dos resíduos municipais, 2) a eutrofização, 3) o lixo marinho e 4) a alteração física e destruição de habitat. Adicionalmente, são também identificados os desafios emergentes que se colocam às zonas costeiras e marinhas, decorrentes da extensão e magnitude destes impactos e que se seguem:

- O número de "zonas mortas" tem dobrado a cada década desde 1960, totalizando atualmente cerca de 150 no planeta, como resultado do sobreenriquecimento das águas em nutrientes que as privam de oxigênio e de vida. Os fluxos crescentes de nitrogênio são trazidos principalmente pelo escoamento da agricultura, pelos compostos de nitrogênio veiculados pelo ar derivados da queima de combustíveis fósseis e pelas descargas de resíduos humanos.

- As descargas de água doce nas zonas costeiras estão diminuindo. As descargas fluviais diminuíram cerca de 15\% mundialmente devido sobretudo à construção de barragens, o que está afetando drasticamente os padrões de salinização, tais como os fluxos de nutrientes e sedimentos que são essenciais para manter as funções regenerativas que as zonas costeiras têm para os ecossistemas marinhos.

- As zonas úmidas costeiras estão cada vez mais degradadas. Usadas por espécies migratórias para desova e também como áreas de berçário, são de grande importância para a manutenção de ecossistemas marinhos.

- Novos químicos estão sendo lançados para o ambiente. Além dos já conhecidos poluentes orgânicos persistentes e metais, centenas de outros novos e desconhecidos químicos estão sendo lançados diariamente para o ambiente. 
- A existência de habitats naturais em boas condições representa uma proteção fundamental para as zonas costeiras contra eventos como inundações e tsunamis.

- O aumento do nível médio do mar é um desafio real para a gestão costeira devido à salinização e às alterações físicas que irá causar nas zonas costeiras.

Assim, perante a certeza que os impactos antropogênicos sobre as ecossistemas costeiros vão continuar e que certamente serão agravados pelas mudanças climáticas previstas, o futuro que se desenha para as zonas costeiras é complicado e respostas urgentes nunca foram tão necessárias. A natureza dessas respostas, assim como a sua contextualização serão o tópico da discussão a seguir.

\subsection{Mudanças no Contexto Mundial e a Necessidade de Integração na Procura de uma Resposta.}

O Homem é desde há muito tempo um agente ativo de transformação do ambiente. No entanto, esta transformação tomou proporções de tal maneira impactantes, sobretudo após a $1^{\text {a }}$ Revolução Industrial, que hoje em dia observa-se uma degradação ambiental alarmante. O estado atual das zonas costeiras é, pois, um perfeito reflexo do resultado desse padrão de desenvolvimento tão presente na história do Homem.

Contudo, no final do séc. XX assistiu-se a uma tomada gradual de consciência da gravidade da situação por parte da sociedade. Esta conscientização ocorreu, em grande parte, devido aos alertas da comunidade científica, que se debruçava cada vez mais sobre as causas e conseqüências destes anos acumulados de agressões ao ambiente, mas também devido ao aumento de informação, fazendo com que se deixasse de assistir passivamente às conseqüências do crescimento econômico como até então. Como conseqüência, as nações do mundo viram-se obrigadas a colocar a questão ambiental no topo de suas agendas. 
Em seguida são apresentados alguns dos principais fatos que ocorreram no mundo nos finais do séc. XX e início do séc. XXI que foram fundamentais para essa mudança de visão, dando especial ênfase às conseqüências que tiveram para a gestão dos sistemas naturais e em particular das zonas costeiras.

Considera-se esta análise essencial para a compreensão da evolução do escopo da gestão costeira que será retratada no capítulo seguinte. Estes fatos serão, no entanto, apenas aflorados, de maneira a contextualizar as mudanças ocorridas no campo da gestão costeira, uma vez que o seu aprofundamento está fora do escopo do presente trabalho.

\subsubsection{Os Impactos da Globalização e suas Disparidades}

A globalização, entendida como um processo de integração de fluxos (de comércio, de capital, de trabalho e de informação) e das políticas que facilitam esses fluxos (como a redução de barreiras ao comércio, os fluxos financeiros e a migração), foi um dos fatores que contribuiu para uma forte aceleração da degradação ambiental do planeta. Por outro lado, contribui igualmente para um fortalecimento da mudança de comportamento por parte da sociedade em relação a essa degradação, sobretudo após o fim da Guerra Fria, quando este processo tomou proporções verdadeiramente planetárias (Aggarwal, 2006).

Os impactos desta expansão excessiva do comércio internacional no meio ambiente são de duas ordens, segundo Daly (1996 apud Romeiro, 1999): a primeira é relativa aos impactos sócio-ambientais locais (degradação ambiental e/ou esgotamento precoce dos recursos naturais) e a segunda diz respeito à escala das atividades econômicas.

A magnitude dos impactos socioambientais locais pode resultar das diferenças entre países em termos de grau de incorporação dos custos sociais e ambientais. Este costuma ser menor nos países desenvolvidos, pois com a abertura das barreiras comerciais, estes puderam passar a totalidade ou parte dos seus processos de produção para países mais pobres (que geralmente apresentam mão de obra mais barata, recursos naturais mais abundantes e legislação ambiental menos restritiva ou inexistente). 
Quanto à escala das atividades econômicas, esta geralmente tende a ultrapassar os limites da capacidade de carga do ecossistema, colocando a sua subsistência em perigo, uma vez que a produção deixou de estar limitada pela dimensão do mercado interno.

Aggarwal (2006) argumenta ainda que os problemas ambientais e sociais decorrentes deste processo são conseqüência de uma globalização do modelo consumista típico das sociedades industrializadas, sustentado por teorias econômicas neoclássicas focadas exclusivamente na produtividade. Estas não tomam em consideração a resiliência do ecossistema de onde são extraídos os recursos, causando deste modo danos ambientais gravíssimos, acompanhados de uma diminuição de qualidade de vida e de um aumento de exclusão social e pobreza.

Assim, embora a globalização tenha gerado vários benefícios sociais e econômicos, o passivo ambiental e a desigualdade social decorrentes ficaram cada vez mais notórios e evidentes (graças também ao aumento do acesso à informação trazido pela revolução telemática). Isto levou ao aparecimento de críticas por parte da sociedade, que advogavam novos modelos de crescimento e produção, onde o sistema Homem-Natureza fosse considerado como um todo, ao invés de separado e independente (Aggarwal, 2006).

Relativamente aos ecossistemas costeiros estas conseqüências da globalização têm se demonstrado especialmente graves. A constatação destes fatos pela sociedade foi de particular importância para a gestão costeira, uma vez que tornou necessária uma visão mais abrangente quanto aos fatores que afetam as zonas costeiras, assim como mostrou que sem novas medidas gerenciais, a aceleração da degradação tornar-se-ia incontornável.

\subsubsection{A Introdução da Sustentabilidade nas Agendas Políticas.}

O modelo econômico de crescimento centrado no lucro e produtividade, sem consideração alguma pela fragilidade e capacidade de carga do ecossistema e com fortes assimetrias quanto aos benefícios socioeconômicos entre países e populações, começou a ser contestado inicialmente nos anos 1960, 1970. 
O primeiro alerta em relação às conseqüências que esse modelo de crescimento iria ter para a humanidade foi feito pelo Clube de Roma (Meadows, 1972), que denunciava, através do seu livro Limites ao Crescimento, que o crescimento da população e do consumo estavam ocorrendo a um ritmo exponencial enquanto que os recursos naturais eram finitos e limitados. Desta forma, propuseram um novo modelo de crescimento global em equilíbrio, introduzindo variáveis importantes como o respeito à capacidade de carga da biosfera e à necessidade de um sistema mundial sustentável (Diegues, 2001). Surgiam, assim, as primeiras análises sistêmicas sobre os limites externos do crescimento material em nível planetário. Foi neste contexto que aconteceu a Conferência de Estocolmo, em 1972, onde se debateu pela primeira vez temas centrais relativos ao crescimento econômico, desenvolvimento e proteção ambiental.

Foi a partir desse momento que cresceu o debate sobre a revisão de conceitos desenvolvimentistas, propondo-se modelos alternativos de crescimento e estilos diferentes de desenvolvimento, como resultado da percepção cada vez mais forte da comunidade científica de que os impactos das atividades humanas sobre os ecossistemas tinham se amplificado a ponto de colocar em risco a própria sobrevivência da espécie humana a longo prazo (Diegues, 2001; Rebouças et al, 2006).

Surgia então o conceito de ecodesenvolvimento (Sachs, 1986) que, segundo Rebouças et al. (2006), tratava-se ao mesmo tempo de um novo estilo de desenvolvimento e planejamento, orientado para considerar adequadamente a satisfação das necessidades fundamentais das populações, a prudência ecológica e a sustentabilidade econômica. O ecodesenvolvimento, segundo Sachs (op.cit.), era um estilo de desenvolvimento que preconizava a existência de soluções específicas para os problemas particulares de cada região e que estas tinham de levar em conta os dados ecológicos da mesma forma que os culturais e econômicos.

A existência de uma incontornável interdependência entre ambiente e desenvolvimento, entre setores e entre nações foi constatada pela Comissão Mundial sobre Meio Ambiente e Desenvolvimento - CMMAD (também conhecida por Comissão Brundtland), que através do seu relatório "O Nosso Futuro Comum" publicado em 1987, alertava para a necessidade de um novo modelo de desenvolvimento, um que "satisfaça as necessidades, desejos e expectativas das presentes gerações sem comprometer a capacidade das próximas gerações em 
satisfazer suas necessidades, desejos e expectativas" (CMMAD, 1988). Constituíase, assim, a expressão "desenvolvimento sustentável".

Cicin-Sain (1993), baseada no trabalho da Comissão Brundtland, definiu o desenvolvimento sustentável como um processo contínuo de tomada de decisão, cuja filosofia é a da promoção de um desenvolvimento que permita o aumento da qualidade de vida das pessoas (ao assegurar uma distribuição justa e igual dos benefícios decorrentes), mas que seja também ambientalmente apropriada. Para tal, ter-se-á de fazer uso correto dos recursos naturais, assegurar a proteção dos processos ecológicos e dos sistemas de suporte à vida, assim como da diversidade biológica.

Segundo Vallega (1999), baseado no trabalho de Young (1992), o desenvolvimento sustentável correspondia, portanto, a uma mudança de pensamento, onde a produtividade econômica deixaria de ser o único motor de desenvolvimento das nações. A prioridade passava a ser um sistema de metas tripartido, onde (1) a integridade do ecossistema, (2) a eficiência econômica e (3) a equidade social, incluindo o direito das gerações futuras, passariam a ter a mesma importância para o desenvolvimento.

A adoção formal deste conceito como princípio orientador para o desenvolvimento das nações aconteceu em 1992 no Rio de Janeiro, durante a Conferência das Nações Unidas sobre Meio Ambiente e Desenvolvimento (CNUMAD). Através da sua Declaração de Princípios, o Homem transformou-se no centro das preocupações do desenvolvimento sustentável (Princípio 1) e a proteção do meio ambiente numa parte integrante do processo de desenvolvimento, sem poder ser considerada de forma isolada (Princípio 4) (UNEP, 1992).

Ficou igualmente destacada - através da Agenda 21, o plano de ação emergente da CNUMAD- a importância dos oceanos e das zonas costeiras para a manutenção do sistema global de suporte à vida e da oportunidade positiva que estes sistemas representam para o desenvolvimento sustentável (Cicin-Sain, 1993).

Consequentemente, a Agenda $21 \mathrm{fez}$ com que a gestão integrada se transformasse numa meta global e, em particular, para as zonas costeiras, pois através do seu capítulo 17, a gestão costeira integrada foi considerada como um instrumento para a promoção de um desenvolvimento costeiro sustentável. O conteúdo deste documento e a sua relevância para a Gestão Costeira Integrada serão discutidos mais à frente. 
O conceito de desenvolvimento sustentável trouxe, portanto, para a gestão costeira, a necessidade de se ter uma única meta, que seria fruto da correlação entre as diferentes metas específicas de cada zona costeira.

\subsubsection{O Reconhecimento das Mudanças Globais}

Outro fator igualmente importante que ocorreu no cenário mundial no início do séc. XXI foi o reconhecimento da existência de mudanças globais como resultado das atividades antropogênicas (IGPB, 2001; IPCC, 2001, 2007). Os programas internacionais de pesquisa sobre mudanças climáticas, em particular os estudos sobre as conseqüências do aumento do nível do mar devido ao aquecimento atmosférico, possibilitaram as primeiras previsões de cenários de erosão costeira. Estas mostravam que as zonas costeiras viriam a ser áreas particularmente afetadas pelas mudanças climáticas globais, com graves conseqüências socioeconômicas e ambientais para as nações (Vallega, 1999).

De acordo com o mesmo autor, a pesquisa centrada nas mudanças globais pôs em evidência o efeito acumulado que a presença do Homem e das suas atividades estavam gerando sobre o meio-ambiente, cujos principais impactos eram precisamente mais sentidos nas zonas litorâneas mundiais. O conhecimento cada vez mais detalhado destes processos e a constatação da estrutura organizacional existente na altura nas zonas costeiras tornou evidente a necessidade de programas específicos de gestão costeira que fossem capazes de se adaptar a estas mudanças no sistema Terra.

\subsubsection{Mudanças Epistemológicas na Concepção do Mundo}

Finalmente, importantes mudanças de natureza epistemológica levaram a uma nova visão do mundo e das relações existentes entre os seus componentes. Essa proposta tomou forma com os trabalhos de Edgard Morin, que através da sua Introdução ao Pensamento Complexo (2001), advogava que existiam fenômenos que não se conseguem explicar e que o mundo é um sistema em que suas partes não podem ser estudadas sem a compreensão e aceitação do todo onde figuram, sendo que essas relações sistêmicas não podem ser explicadas pela lógica (Morin, 
1999). Assim, a abordagem tradicional que preconizava uma análise setorial, tal como uma descrição exaustiva da realidade de acordo com os princípios do positivismo e estruturalismo, começou a ser posta de parte diante do papel inovador da teoria da complexidade que, ao contrário, promovia uma visão holística dos sistemas (Vallega, 1999).

Isto se tornou particularmente claro para a problemática das zonas costeiras, onde era cada vez mais notório que tanto os componentes biofísicos do ambiente, como a população humana e seu complexo socioeconômico tinham de ser entendidos como partes constitutivas e interdependentes de um ecossistema. Verificava-se, portanto, que a linha de pensamento tradicional não era adequada para se prosseguir com uma visão integrada do sistema, como defendido na Agenda 21 (Vallega, 1999). A teoria da complexidade veio, assim, tornar possível construir um arcabouço metodológico baseado no conceito de gestão integrada (Vallega, 1999).

Em conclusão, pode-se dizer que a globalização, ao transformar o mundo numa "aldeia global", espalhou um padrão de desenvolvimento enraizado na produtividade o que agravou ainda mais o estado do ambiente do planeta, ao exacerbar os efeitos das mudanças climáticas mundiais. Porém, a interferência do Homem em processos globais mostrou claramente como ele é uma parte indissociável do ecossistema e que sem o estudo desse complexo Homem-Natureza e de suas interligações, qualquer medida tomada no âmbito de gerir sustentavelmente as atividades humanas está condenada a falhar.

Esta realidade é ainda mais visível nas zonas costeiras que, apesar de terem grande importância ecológica e socioeconômica, encontram-se altamente pressionadas e degradadas pelas atividades humanas, fruto da falta de uma visão integrada dos seus componentes e de uma gestão adequada. Estes fatos tornaramse ainda mais evidentes com as mudanças que ocorriam no contexto mundial e convergiram numa mesma meta para os sistemas costeiros, a da gestão integrada das zonas costeiras.

\section{2 - A GESTÃO COSTEIRA: ASPECTOS DA SUA EVOLUÇÃO E PARADIGMA ATUAL}




\subsection{A História e Evolução da Gestão Costeira}

\subsubsection{A gestão costeira como disciplina independente}

Os ambientes costeiros e seus recursos começaram a ser explorados pelo Homem há milhares de anos, mas foi apenas em meados do séc. XIX que se começou a assistir a grandes modificações nestes ambientes.

A inovação tecnológica que se observou durante a Revolução Industrial, possibilitou o desenvolvimento de novas máquinas e a construção de grandes obras de engenharia civil que ofereceram ao Homem os meios para explorar os recursos naturais coincidentes com o pensamento regente da época, o do crescimento econômico a todo o custo. Nessa altura, os recursos naturais eram considerados ilimitados e vistos como produtos a serem consumidos para a obtenção de lucro (Kay \& Alder, 2005).

Esta visão, no entanto, começaria a mudar no final do séc. XIX devido a mudanças de atitude por parte da sociedade. De acordo com os mesmos autores, estas mudanças foram motivadas pelo reconhecimento de que a destruição do ambiente, que estava sendo permitida a favor do desenvolvimento econômico, poderia vir eventualmente a afetar a sua própria sobrevivência.

O planejamento do uso da terra foi, assim, uma atividade que surgiu nessa altura e que se expandiu durante o início do séc. $X X$, de maneira a tentar separar os conflitos que derivavam das prolíferas atividades humanas. Começam então a aparecer os primeiros zoneamentos e planejamentos de áreas públicas, mas cujos resíduos urbanos passam a ter como destino as águas costeiras. No entanto, a expansão urbana levaria à necessidade de desenvolver a zona costeira para acomodar novas áreas residenciais e industriais, o que obrigou a que fosse dada mais atenção ao uso que se estava fazendo desta zona. O seu potencial recreativo, cada vez mais valorizado e solicitado pela população, também foi um fator que impulsionou o gerenciamento que ali se instalava gradualmente (Kay \& Alder, 2005).

Assiste-se então a uma diversificação de ações humanas nestas áreas que operaram independentemente durante vários anos, fazendo com que as zonas costeiras crescessem com base em diretivas orientadas para o planejamento do uso 
da terra. Seria apenas no final da década de 1960, início da década de 1970, que a gestão costeira surgiu como disciplina independente.

Desde então, o âmbito da gestão costeira foi profundamente alterado. As mudanças ocorridas na sociedade, assim como avanços científicos em relação às causas e conseqüências dos problemas ambientais que estavam degradando o planeta e em particular as zonas costeiras, pediam medidas mais eficientes para lidar com esse cenário, como retratado em seguida.

\subsubsection{A Evolução do Escopo}

Coube aos países desenvolvidos desencadear as iniciativas para gerir as suas costas devido à degradação ambiental então observada e cujas causas estavam precisamente no crescimento desordenado e mal planejado. Os Estados Unidos foram a primeira nação a adotar formalmente um plano nacional de gerenciamento costeiro, o Coastal Zone Management Act, em 1972, conferindo, assim, um contexto político à gestão costeira. Este instrumento legal definia objetivos, enunciava conceitos e princípios e fornecia linhas orientadoras que foram subsequentemente usadas por várias nações do mundo, e em particular por países em desenvolvimento, para iniciarem os seus programas de gerenciamento costeiro (Cicin-Sain \& Knecht, 1998; Vallega, 1999).

Este programa surgiu como resposta aos problemas decorridos do uso dos recursos costeiros. Aliás, esta seria a principal razão pela qual surgiram inicialmente os programas de gerenciamento costeiro. Assim, estes eram geralmente elaborados após um período de crescente pressão pública, política e científica sobre o governo para lidar com estes problemas e resolvê-los. Todavia, este era inicialmente um processo bastante moroso e geralmente existia uma defasagem considerável entre a identificação dos problemas e a elaboração de respostas. No caso específico do Coastal Zone Management Act, ele surgiu após um período de cerca de 12 anos de contestações, o que de resto se passou de maneira similar mais tarde na União Européia (Kay \& Alder, 2005).

Porém, essa situação viria a mudar pouco tempo depois graças a mudanças que ocorriam não só na esfera nacional, mas também internacional. Assim, o rápido desenvolvimento de novos instrumentos conceituais, o debate cada vez mais intenso entre a comunidade científica, o estreitamento das relações entre esta e a esfera 
política e o trabalho pioneiro das Nações Unidas fez com que durante a década de 1980 se assistisse a uma difusão de programas de gerenciamento costeiro (Vallega, 1999).

Esta visibilidade notória e crescente dada ao campo emergente da gestão costeira teve como conseqüência uma mudança profunda no escopo destes programas na década de 1990. Houve uma transição da abordagem inicialmente orientada por políticas de ordenamento terrestre e que contemplavam poucos usos, para uma abordagem focada e direcionada para as áreas costeiras. As áreas consideradas passaram então a ser cada vez maiores, tanto do lado terrestre como marinho, de maneira a poder considerar-se a interdependência entre os múltiplos usos que se desenvolviam e o ecossistema (Cicin-Sain \& Knecht, 1998).

O "ponto de viragem" para a gestão costeira foi, então, a Conferência das Nações Unidas sobre Meio Ambiente e Desenvolvimento (CNUMAD), em 1992, onde se acordou que o tipo de gestão necessária para gerenciar as costas mundiais era o de uma "gestão costeira integrada", conceito que se tornou uma parte integrante do capítulo sobre as costas e os oceanos da Agenda 21. A Agenda 21 é um plano de ações contendo 40 capítulos e que pretendia servir de roteiro para guiar as nações signatárias da CNUMAD (a totalidade das participantes) na direção do desenvolvimento sustentável.

Tal acontecia devido ao reconhecimento de que os ecossistemas costeiros e marinhos estavam sendo impactados por várias forçantes e que necessitavam mais do que nunca de uma abordagem integrada e compreensiva dos seus usos e conflitos (Cicin-Sain \& Knecht, 1998). Acontecia, assim, uma mudança de paradigma na gestão costeira que passou da visão tradicional setorialista para uma abordagem integrada e holística (Vallega, 1993). Os aspectos inovadores desta nova proposta de gerenciamento costeiro serão discutidos mais à frente, quando se definirá com maior profundidade este conceito.

Após a CNUMAD, o conceito de gestão costeira integrada como um meio para atingir o desenvolvimento sustentável das zonas costeiras foi crescentemente reconhecido (Tobey \& Volk, 2002; Cicin-Sain et al., 1995) e adotado em várias convenções e acordos regionais e internacionais (Cicin-Sain et al., 2002), havendo assim uma proliferação de esforços nesse sentido pelas nações mundiais.

Em 1993, Sorensen (1993) estimava que cerca de 142 esforços de gestão costeira integrada tinham sido iniciados por aproximadamente 57 estados soberanos 
ou semi-soberanos. Ao conduzir um novo levantamento em 2002, o mesmo autor identificou 622 esforços em 145 nações, de entre as quais 99 correspondiam a países em desenvolvimento (Sorensen, 2002).

A importância da gestão costeira integrada voltaria a ser reforçada durante a cúpula mundial para o desenvolvimento sustentável em Joanesburgo em 2002, onde no Plano de Implementação proposto, as nações foram convidadas a promover uma gestão costeira e marinha de forma integrada, multidisciplinar e multisetorial ao nível nacional, e a encorajar e ajudar os estados costeiros a desenvolver políticas dos oceanos e mecanismos para uma gestão costeira integrada (UN, 2002).

Esta evolução do escopo da gestão costeira encontra-se sumarizada na Tabela 4, onde se apresenta a mudança dos aspectos-chave que levaram ao foco atual e praticado hoje em dia, bem como o caminho para o qual está seguindo.

Em resumo, a gestão costeira evoluiu, portanto, nos últimos 40 anos de programas meramente reativos à degradação ambiental e, portanto, direcionados a problemas considerados urgentes (décadas de 1960, 1970) para uma combinação de programas reativos e pró-ativos, fruto das mudanças sociais, políticas e científicas que ocorriam no contexto mundial (década de 1980, década de 1990) para finalmente entrar na fase atual, onde o foco é a promoção e concretização da gestão costeira integrada e cujo âmbito será definido em seguida.

\subsection{O Paradigma Atual: A Gestão Costeira Integrada}

\subsubsection{A base referencial: a Agenda 21}

Como mencionado anteriormente, o conceito de gestão costeira integrada, doravante chamado $\mathrm{GCl}$, foi considerado central para o gerenciamento dos oceanos e das costas pelas nações do mundo no capítulo 17 da Agenda 21 da CNUMAD. O capítulo 17 trata das ações específicas para os oceanos e costas e é intitulado "Proteção dos Oceanos, de Todos os Tipos de Mares - Inclusive Mares Fechados e Semifechados - e das Zonas Costeiras, e Proteção, Uso Racional e Desenvolvimento de Seus Recursos Vivos".

Este documento é de extrema importância para a contextualização da $\mathrm{GCl}$ uma vez que é no seu conteúdo que se encontra retratado pela primeira vez a 
necessidade de uma abordagem integrada para a resolução dos problemas ambientais observados nos oceanos e zonas costeiras (Cicin-Sain \& Knecht, 1998). Assim, pode-se ler na introdução do capítulo 17 (par 17.1) que "novas abordagens de gerenciamento e desenvolvimento marinho e costeiro são exigidas, abordagens integradas do ponto de vista do conteúdo e que ao mesmo tempo se caracterizem pela precaução e pela antecipação".

\begin{tabular}{|c|c|c|c|}
\hline Fase & Período & Objetivo & Aspectos Principais \\
\hline 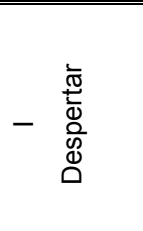 & $1950-1970$ & $\begin{array}{l}\text { Gestão do uso frente a um } \\
\text { único conflito ambiental, visto } \\
\text { pela sociedade como } \\
\text { importante }\end{array}$ & $\begin{array}{ll}\text { - } & \text { Abordagem setorial } \\
\text { - } & \text { Lógica Homem vs Natureza } \\
\text { - } & \text { Considerações ecológicas limitadas } \\
\text { - } & \text { Foco reativo }\end{array}$ \\
\hline 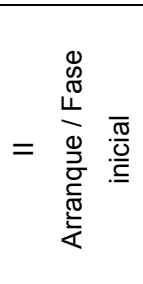 & $1970-1990$ & $\begin{array}{l}\text { Gestão do uso e Proteção } \\
\text { Ambiental }\end{array}$ & $\begin{array}{l}\text { - } \text { Aumento de avaliações ambientais } \\
\text { - } \text { Maior integração e coordenação entre setores } \\
\text { - } \text { Aumento Participação Pública } \\
\text { - Maior percepção ecológica } \\
\text { - Continuação da predominância da Engenharia } \\
\text { - Foco combinado reativo e próativo }\end{array}$ \\
\hline 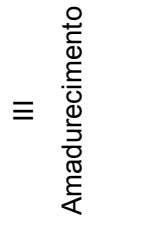 & $1990-2000$ & Gestão integrada & $\begin{array}{l}\text { - Foco no desenvolvimento sustentável } \\
\text { - Maior ênfase na gestão ambiental compreensiva } \\
\text { - Recuperação ambiental } \\
\text { - Ênfase na participação pública }\end{array}$ \\
\hline$\geq \frac{\frac{0}{\frac{0}{0}}}{\frac{\pi}{0}}$ & $2000-2010$ & Gestão Integrada & $\begin{array}{l}\text { - Foco na implementação tangível dos princípios do } \\
\text { - } \text { desenvolvimento sustentável } \\
\text { - Emernos passam a adotar uma gestão ecossistêmica } \\
\text { - Exploração de novos métodos de gestão costeira, } \\
\text { incluindo redes de aprendizado e sistemas de gestão } \\
\text { adaptativa } \\
\text { - Aumento do impacto da globalização e da Internet nas } \\
\text { - Ebordagens e resultados do gerenciamento } \\
\text { Emergência de uma nova avaliação dos princípios } \\
\text { básicos da gestão costeira }\end{array}$ \\
\hline 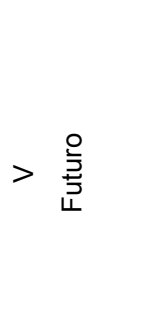 & $2010-?$ & Gestão integrada & $\begin{array}{l}\text { - Conjunto integrado de teorias e ferramentas validadas } \\
\text { para aplicação em todas as escalas, períodos, } \\
\text { localidades e conflitos } \\
\text { - Gestão ecossistêmica compreensiva } \\
\text { - Comunidades que praticam a gestão costeira } \\
\text { - } \text { interconectadas } \\
\text { - Conjunto de modelos de governança validados }\end{array}$ \\
\hline
\end{tabular}


O capítulo 17 encontra-se subdividido em 7 partes, mas apenas se comentará sobre a primeira, intitulada "Gerenciamento Integrado e Desenvolvimento Sustentável das Zonas Costeiras, Inclusive Zonas Econômicas Exclusivas" pois é a que trata do gerenciamento integrado e da sua importância para as zonas costeiras.

É constatado neste capítulo (parágrafo 17.4) "que apesar dos esforços nacionais, sub-regionais, regionais e mundiais, verifica-se que as maneiras como atualmente se aborda o gerenciamento dos recursos marinhos e costeiros nem sempre foram capazes de atingir o desenvolvimento sustentável; e os recursos costeiros, bem como o meio ambiente costeiro, vêm sofrendo um processo acelerado de degradação e erosão em muitos lugares do mundo", deixando assim claro que o tipo de gerenciamento adotado nas zonas costeiras e marinhas até à data não tinha sido capaz de oferecer soluções eficazes na proteção e conservação destas zonas e dos seus recursos.

Desta forma e para combater esta realidade, os estados costeiros comprometiam-se a "praticar um gerenciamento integrado e sustentável das zonas costeiras e do meio ambiente marinho sob suas jurisdições nacionais" (parágrafo 17.5). Para tal, teria de ser dada particular atenção a que o processo de tomada de decisão e de definição de políticas procurasse integrar os interesses e metas dos vários setores econômicos, promovendo a sua compatibilização, para deste modo atingir um uso equilibrado destas zonas. Os princípios da precaução e da prevenção, assim como a participação do público, foram considerados elementos chave para atingir estes objetivos.

Esta integração de políticas e tomada de decisões teria de ser devidamente assegurada tanto ao nível local como nacional ao estabelecer-se ou fortalecer-se mecanismos de coordenação para o gerenciamento integrado e o desenvolvimento sustentável das zonas costeiras e marinhas e dos respectivos recursos naturais (parágrafo 17.6). Acrescenta ainda que "tais mecanismos devem incluir consultas, conforme apropriado, aos setores acadêmico e privado, às organizações nãogovernamentais, às comunidades locais, aos grupos usuários dos recursos e às populações indígenas" (parágrafo 17.6).

Por último, fica explícito que mais e melhor informação deverá ser obtida sobre os processos e sistemas costeiros, não só relativamente aos seus componentes físicos e biólogicos, mas também levando em conta as variáveis sócio- 
econômicas (parágrafo 17.8). Conseqüentemente, deverão ser feitos esforços no sentido de capacitar recursos humanos na gestão integrada costeira e marinha, assim como de promover programas piloto e projetos dessa natureza (parágrafo 17.17).

O capítulo 17 da Agenda 21 acabou sendo alvo de várias críticas em razão de não ter explicitado mais objetivamente as suas metas, deixando-as algo vagas e com estratégias pouco definidas (Vallega, 1993; Cicin-Sain \& Knecht, 1998). No entanto, os avanços adquiridos durante a CNUMAD em relação às zonas costeiras e oceanos foram muito significativos, pois se conseguiu obter consenso internacional quanto aos maiores problemas que afetavam estas áreas e quanto aos princípios que deveriam nortear as ações dirigidas para os solucionar (Cicin-Sain \& Knecht, 1998)

O conceito da gestão integrada costeira e dos oceanos ganhou, portanto, durante a CNUMAD, a legitimidade política que necessitava para ser aceite pelos governos como prática, algo que tinha permanecido até então apenas no meio acadêmico (Cicin-Sain \& Knecht, 1998).

A Agenda 21 lançou então o repto para que as atenções se voltassem para o conceito da gestão costeira integrada. A sua importância para o futuro das zonas costeiras foi prontamente reconhecida, tendo-se nos anos seguintes observado uma proliferação de esforços para definir os seus princípios, objetivos e elementos básicos, algo que será retratado em seguida.

\subsubsection{Definição e Metas da GCI}

Após a CNUMAD, houve um grande esforço em nível internacional e regional para elaborar roteiros onde os princípios e práticas da $\mathrm{GCl}$ fossem acordados e estabelecidos (onde se destacam OECD, 1993; UNEP, 1995; World Bank, 1996; Barusseau et al, 1997; FAO, 1998), de maneira a que existisse entendimento quanto aos objetivos buscados e portanto, uma base comum para o direcionamento dos trabalhos.

Essa preocupação refletiu-se igualmente na comunidade científica, que nos últimos anos também procurou definir as principais características do gerenciamento 
costeiro integrado (ver, por ex. Chua, 1993; Cicin-Sain, 1993; Vallega, 1993; Clark, 1997; Olsen et al., 1997), de maneira a melhor definir, interpretar e operacionalizar este conceito. Assim, embora certos aspectos tenham tido mais ênfase do que outros nestes trabalhos, existe, atualmente, uma aparente concordância quanto à definição e escopo da GCl (Olsen et al., 1997; Cicin-Sain e Knecht, 1998).

A GCl pode então ser definida como um processo dinâmico e contínuo que visa o uso, o desenvolvimento sustentável e a proteção das áreas costeiras (GESAMP, 1996), tendo que ter necessariamente uma abordagem multi-setorial e integrada para ser realizada com sucesso (Cicin-Sain e Knecht, 1998). Preconiza também que haja um envolvimento ativo e sustentado do público e das partes afetadas pelo modo como os recursos costeiros são distribuídos e os conflitos mediados (GESAMP, 1996).

O objetivo principal da $\mathrm{GCl}$ é o de melhorar a qualidade de vida das comunidades humanas que dependem dos recursos costeiros, conservando a diversidade biológica e produtividade desses ecossistemas (GESAMP, 1996). Para cumprir este objetivo, a maioria dos programas de $\mathrm{GCl}$ procura concretizar três grandes metas, como analisado por Cicin-Sain e Knecht (1998): 1) promover o desenvolvimento sustentável das áreas costeiras e marinhas; 2) reduzir a vulnerabilidade das áreas costeiras e dos seus habitantes a desastres naturais; e 3) manter os processos ecológicos, os sistemas de suporte à vida e a diversidade biológica das áreas marinhas e costeiras.

\subsubsection{Conceitos Principais da GCI}

Para assegurar a realização das suas metas, a $\mathrm{GCl}$ tem algumas premissas fundamentais implícitas na sua abordagem dos problemas costeiros, que não estavam contempladas na gestão costeira até o surgimento e adoção deste conceito. Como foi visto, a gestão tradicional abordava as questões costeiras com uma visão setorialista, sem procurar enquadrá-las no contexto maior onde estavam inseridas, nem tampouco com uma visão a longo-prazo, tornando-a ineficiente perante a natureza e grau dos impactos.

Para se poder atingir o tão almejado desenvolvimento sustentável costeiro, a gestão costeira precisava ter uma abordagem que permitisse lidar com a 
variabilidade do sistema costeiro e das relações existentes entre os seus componentes. Desta forma, vários princípios oriundos da Declaração do Rio foram adotados pela $\mathrm{GCl}$, levando a que a abordagem preconizada por este processo fosse orientada no sentido de que os conflitos costeiros passassem a ser analisados sob uma nova perspectiva. Estes aspectos são discutidos em seguida, pois representam o verdadeiro diferencial quanto à maneira como os problemas e conflitos costeiros passaram a ser tratados.

\section{- Enfoque adaptativo.}

A gestão adaptativa ${ }^{4}$ implica, por um lado, que sejam incluídos métodos científicos no design, planejamento, implementação e avaliação de estratégias gerenciais e, por outro, que sejam consideradas questões ambientais, econômicas e sociais no desenvolvimento de políticas e ações gerenciais voltadas para o meioambiente. É também dada ênfase à necessidade de se incorporar no processo de gestão tanto o conhecimento pré-existente, oriundo de disciplinas naturais e sociais, como a incerteza (Schreiber et al, 2004).

A GCl adota este conceito na sua abordagem, pois o contexto na qual ela incide não é estático. Pelo contrário, o ambiente costeiro, entendido como um complexo formado pelo sistema humano e natural, é altamente sensível a fatores políticos, socioeconômicos e ecológicos e cuja variabilidade tem de estar contemplada no seu planejamento (GESAMP, 1996; Chua et al, 2006).

Desta forma, o enfoque adaptativo da $\mathrm{GCl}$ faz com o processo de gestão evolua segunda a lógica adotada do método científico do "aprender pelo fazer" (learning by doing). Ou seja, as ações gerenciais são consideradas fatores a serem manipulados de maneira a distinguir entre hipóteses alternativas, enquanto que os efeitos dessas ações no sistema são medidos em relação a objetivos previamente determinados e que incluem toda a complexidade das interações socioeconômicas, políticas e ambientais. Ao se adotar esta maneira de proceder na $\mathrm{GCl}$, pretende-se, portanto, que o aprendizado que se vai adquirindo durante a aplicação de

\footnotetext{
${ }^{4} \mathrm{O}$ conceito de gestão adaptativa surgiu nos final dos anos 1970 (Holling, 1978) como uma forma de melhorar a gestão dos recursos naturais, face à ineficiência (ou inexistência) dos métodos aplicados até então para lidar com a degradação ambiental verificada nessa altura.
} 
experiências gerenciais vá contribuindo ou mesmo definindo mais adiante o desenvolvimento de novas ações gerenciais (Schreiber et al, 2004).

Outro aspecto essencial do processo adaptativo e que foi incorporado pela GCl é o papel central que a monitorização tem para este processo (Schreiber et al, 2004). O aprendizado só pode ocorrer se parâmetros identificados na fase inicial puderem ser comparados contra as metas específicas que foram estabelecidas na fase de planejamento, para, desta maneira, verificar se as hipóteses delineadas podem ser aceitas ou se precisam ser redefinidas.

Finalmente, a participação dos stakeholders ${ }^{5}$ é também reconhecida como fundamental para alimentar o processo adaptativo, e de preferência se for assegurada desde os estágios iniciais do design e planejamento (Schreiber et al, 2004; Van den Belt, 2004). Esta colaboração é essencial para garantir uma relação realista entre os problemas gerenciais, constrangimentos de ações possíveis e identificação de resultados alcançáveis. Como a participação tem, de fato, um lugar de destaque na $\mathrm{GCl}$, este aspecto será melhor desenvolvido mais à frente.

Olsen et al (1998) estabelece ainda que, idealmente, uma gestão costeira com uma abordagem baseada no aprendizado requer iniciativas que:

1. explicitem claramente as hipóteses sobre as quais o projeto ou programa é baseado;

2. estabeleçam parâmetros de controle para que mudanças que ocorram nos lugares gerenciados possam ser comparadas com lugares similares que não estão sendo geridos;

3. documentem condições iniciais e monitorem mudanças relevantes na sociedade humana, qualidade do ecossistema e na governança';

4. analisem periodicamente os dados monitorados e retirem conclusões de maneira a aceitar, rejeitar ou modificar as hipóteses testadas;

5. aprendam da experiência e adaptem as estratégias e ações tanto ao que está sendo aprendido como à alteração das condições.

\footnotetext{
${ }^{5}$ Um stakeholder corresponde a qualquer pessoa, grupo ou organização com um interesse num determinado assunto (neste caso, o gerenciamento costeiro), seja porque é diretamente afetado por esse assunto ou porque pode influenciar o seu resultado. Caso se incluam membros do público que ainda não têm consciência que são afetados pelo assunto em causa, então se fala de partes interessadas (na prática, a maioria dos cidadãos individuais e várias pequenas ONGs e empresas) (EC, 2003).

${ }^{6}$ Governança refere-se ao processo pelo qual políticas, leis e instituições lidam com os assuntos que são relevantes para a sociedade (Olsen et al, 1999).
} 
Ao adotar uma gestão adaptativa nos seus procedimentos, a $\mathrm{GCl}$ procurou garantir, portanto, que não se tratasse de um roteiro a ser aplicado para obter os resultados pretendidos, mas antes um processo que se vai redefenindo ao longo do tempo, de acordo com as condições existentes e a experiência acumulada (Olsen et al., 1997).

\section{- Enfoque ecossistêmico.}

A gestão ecossistêmica ${ }^{7}$ é um tipo de gestão regional que integra as dimensões humanas e naturais, objetivando a proteção do ecossistema a longo prazo. Existem várias definições para este conceito, mas o seu aspecto fundamental é que coloca o ecossistema e o ambiente externo circundante como a unidade funcional a ser gerida, uma vez que os limites políticos do ecossistema a ser gerido geralmente não coincidem com os seus limites ecológicos e, portanto, não contemplam todos os elementos necessários para lidar com as questões gerenciais (Pavlikakis \& Tsihrintzis, 2000).

O enfoque ecossistêmico adotado pela GCl é, portanto, caracterizado por trazer uma abordagem holística e sistêmica ao gerenciamento costeiro, cujos princípios e métodos estão direcionados para possibilitar o desenho de soluções que sejam socialmente aceitáveis para os problemas ambientais de uma região. Desta forma, na GCl considera-se que tanto os componentes biofísicos do ambiente, como a população humana e seu complexo socioeconômico são entendidos como partes constitutivas e interdependentes de um ecossistema (Polette \& Vieira, 2005) e que esse ecossistema (ou um conjunto de ecossistemas contíguos) deve, portanto, passar a ser a unidade a partir da qual são analisados os problemas e se desenvolve um plano.

\footnotetext{
${ }^{7}$ O conceito de gestão ecossistêmica (Agee \& Johnson, 1988) surgiu no final dos anos 1980 e à semelhança da gestão adaptativa, foi resultado do insucesso que os métodos tradicionais de gestão dos recursos naturais estavam tendo. Considerada como uma nova abordagem focada no desenvolvimento sustentável, o seu desenvolvimento foi em grande parte devido ao fato da sustentabilidade ter se tornado a meta política de um grande número de agências governamentais e privadas de gestão de recursos (Pavlikakis \& Tsihrintzis, 2000).
} 
Por conseguinte, a GCl é um processo necessariamente compreensivo, onde são examinados tanto os componentes bióticos (onde se inclui o Homem) como abióticos do ecossistema, a influência do ambiente externo (físico e social), os tipos de usos costeiros e a relação entre eles com o sistema (Vallega, 1993).

Adicionalmente, alguns dos princípios elementares da gestão ecossistêmica, como levantado por Pavlikakis \& Tsihrintzis (2000), são perfeitamente concordantes com os objetivos da GCI. Destaca-se entre esses o fato da colaboração entre todos os atores envolvidos no processo ser necessária e fundamental. Adicionalmente, a $\mathrm{GCl}$ também se caracteriza como um processo sensível às particularidades de cada local e necessita, assim, de uma base sólida de informação científica para auxiliar no seu design, planejamento e tomada de decisão.

O ecossistema costeiro deixou, portanto, na $\mathrm{GCl}$, de ser analisado sob um ponto de vista mecanicista, onde os seus elementos constituintes eram analisados separadamente (visão setorialista), para passar a ser analisado na sua totalidade e ao longo do tempo (visão ecossistêmica).

\section{- Enfoque Integrativo}

A integração é outro aspecto essencial na $\mathrm{GCl}$, pois permite não somente assegurar a existência de uma consistência interna entre políticas (e ações) e os programas, mas também que o processo de planejamento não fique dissociado da realidade de implementação (Chua, 1993). Existem várias definições para o significado de integração na gestão costeira (Cicin-Sain, 1993; Cicin-Sain \& Knecht, 1998; Kenchington \& Crawford, 1993; Olsen et al, 1997), mas todas realçam que se trata de juntar diferentes elementos sob o mesmo sistema de gestão costeira. Assim, segundo Cicin-Sain \& Knecht (1998), a integração no contexto costeiro/marinho deve ser procurada e obtida nas seguintes dimensões:

- Integração intersetorial: tanto entre setores costeiros/marinhos - integração horizontal - (como exploração de gás e petróleo, pesca, turismo costeiro, desenvolvimento portuário), como entre estes setores e outros setores ligados a atividades em terra que afetam o ambiente costeiro e oceânico (como a agricultura e manejo de florestas); 
- Integração espacial: entre o lado aquático e terrestre da zona costeira, uma vez que existe uma forte relação entre as atividades baseadas em terra e a qualidade do ambiente costeiro;

- Integração intergovernamental: corresponde à integração vertical, ou seja, entre diferentes níveis do governo (escalas nacional, estadual e local);

- Integração ciência - gestão: entre as diferentes disciplinas que estão relacionadas com a gestão costeira e dos oceanos (como ciências naturais, sociais e engenharia) - integração interdisciplinar, e as entidades governamentais. Apesar das ciências serem fundamentais para fornecerem informação aos gestores da costa e dos oceanos, existe uma tendência para que exista pouca comunicação entre cientistas e gestores;

- Integração internacional: embora a maioria das questões costeiras e oceânicas esteja dentro da esfera de ação dos governos nacionais ou subnacionais, muitas vezes existem problemas com as nações vizinhas, para os quais devem ser procuradas soluções negociadas internacionalmente.

Os mesmos autores referem ainda que a dificuldade de gerir o sistema costeiro com uma visão unitária e multi-setorial está ligada a três fatores, sendo eles a natureza da propriedade, a natureza dos interesses governamentais e a natureza das instituições governamentais, que tendem a ser diferentes consoante as zonas em questão ${ }^{8}$.

A natureza da propriedade varia de zonas onde é majoritariamente privada (áreas interiores) a zonas onde é predominantemente pública (águas costeiras e mar aberto), passando por zonas onde é uma mistura das duas (terras costeiras). Já os interesses governamentais são geralmente de natureza local ou regional nas áreas interiores, passando por uma mistura destes com interesses nacionais nas terras costeiras, para, à medida que se afasta de terra, se tornarem nacionais (mar aberto) e internacionais (mar alto).

Quanto aos interesses institucionais, estão relacionados com o fato de existirem agências em terra, ao nível local ou regional, com vários propósitos e que estão bem consolidadas para lidarem com assuntos como uso do solo e conflitos entre usos. Já no lado aquático, existe uma tendência para só operarem agências

\footnotetext{
${ }^{8}$ Os autores consideram que o espectro costeiro-marinho é formado por cinco zonas: áreas interiores, terras costeiras, águas costeiras, mar aberto e mar alto.
} 
regionais ou nacionais com um único propósito, ligado principalmente a um só uso do oceano, como atividades de pesca ou extração de petróleo.

A existência destas diferenças faz, portanto, com que as instituições envolvidas na gestão destas zonas e as abordagens usadas devam ser comuns e complementares, mas algo diferenciadas.

Cicin-Sain (1993) acrescenta, no entanto, que esta integração deve ser procurada considerando alguns fatores. Primeiro, nem toda a interação entre setores diferentes é problemática e, portanto, necessita de ser gerida. Segundo, a gestão integrada geralmente não substitui a gestão setorial, mas sim complementa-a. E finalmente, a integração de políticas é geralmente melhor sucedida quando realizada num nível burocrático mais alto ao qual está vinculada a gestão setorial, para assegurar que se está tendo uma visão global dos problemas e não fragmentada.

- Enfoque participativo.

O Princípio $10^{9}$ da Declaração do Rio preconiza que todos os usuários e interessados no sistema costeiro e marinho (diferentes esferas do governo, setor privado, instituições de pesquisa e ensino, ONGs, etc.) - os stakeholders, devem estar envolvidos no processo de tomada de decisão. Como mencionado anteriormente, esta necessidade já se encontra contemplada no processo adaptativo adotado pela GCl. No entanto, à semelhança do que acontece com outros processos de desenvolvimento de políticas ambientais (Santos et al, 2006), a gestão participativa é de fato considerada como uma condição sine qua non para se obter sucesso na implementação de um programa efetivo de gestão costeira (Cicin-Sain \& Knecht, 1998; Van den Belt, 2004).

Esta constatação resulta do reconhecimento de que, embora se consiga obter algum sucesso na implementação de medidas e políticas de gestão através de incentivos econômicos e regulamentação, a sociedade apoiará mais facilmente essas políticas se entender as causas do problema e as conseqüências das tomadas de decisão (Stave, 2002). Ora, esse entendimento apenas acontecerá caso se obtenha uma visão partilhada dos problemas e soluções e também se as partes

\footnotetext{
${ }^{9}$ Este princípio refere que as questões ambientais são melhor resolvidas se a participação de todos os cidadãos interessados estiver assegurada, em vários níveis.
} 
afetadas sentirem que o programa proposto pela $\mathrm{GCl}$ é consistente com as suas necessidades e valores (Polette \& Vieira, 2005).

Assim, a gestão participativa, ao assegurar o envolvimento de todos os stakeholders costeiros, sobretudo se o fizer desde os estágios iniciais do programa, melhora significativamente a obtenção de consenso, pois potencializa a responsabilidade social, o aprendizado da cidadania, a integração de valores sociais nas decisões gerenciais e a confiança do público nas decisões e nos tomadores de decisão (Stave, 2002).

A Comissão Européia (2003) acrescenta ainda que os principais benefícios obtidos da participação do público na tomada de decisão são: permitir uma maior percepção dos problemas e da situação ambiental; fazer uso do conhecimento, experiência e iniciativas de diferentes stakeholders e assim melhorar a qualidade dos planos, medidas e gerenciamento; promover aceitação pública, dedicação e apoio aos processos decisórios; assegurar tomadas de decisão mais transparentes e criativas; possibilitar menos litígios, desentendimentos, atrasos e conseqüentemente uma implementação mais efetiva; e promover aprendizado social.

Scarabello Filho (2005) constata, no entanto, que apesar da participação pública ser aceita como uma questão fundamental para a obtenção da sustentabilidade nos processos de planejamento ambiental, o mesmo já não ocorre em relação à necessidade do consenso. Ora, é a obtenção de consenso que promove uma participação autêntica, pois implica forçosamente que ocorram explicitação e assimilação de diversas opiniões e que essas opiniões sejam confrontadas.

Posto isto, Cicin-Sain \& Knecht (1998) consideram que existem dois tipos de participação pública: uma primeira chamada de advice-giving ("troca de conselhos") e a segunda, intitulada de power-sharing ("partilha de poder"). A primeira forma consiste apenas numa troca de informações, onde o governo consulta o público sobre a sua opinião sobre determinados aspectos, mas onde as decisões finais permanecem no poder dos órgãos de gestão dos programas. Já a segunda forma implica que responsabilidades sobre alguns ou mesmo todos os aspectos de um programa de $\mathrm{GCl}$ são delegadas a comunidades locais ou grupos de interesse.

Apesar das diferenças que cada tipo de participação vai propiciar em termos do seu impacto na tomada de decisão, ambas são essenciais para o processo de 
$\mathrm{GCl}$, dependendo da altura em que ocorrem no processo e dos atores em questão. Assim, uma participação de natureza consultiva é mais apropriada quando se pretende apenas conhecer os interesses e as dificuldades dos atores locais ou obter o conhecimento local que geralmente detêm, enquanto que uma participação concreta torna-se necessária para a formulação das metas e ações do plano (CicinSain \& Knecht, 1998; Kay \& Alder, 2005). Polette \& Vieira (2005) afirmam ainda que o grau mais desejável de participação de cada ator deve ajustar-se a sua importância estratégica para o êxito do programa.

Os benefícios da gestão participativa, quando concretizada efetivamente, são, portanto, inúmeros, tanto do ponto de vista das vantagens obtidas em relação ao próprio processo de gestão, como com os relacionados com a tomada de melhores decisões. No entanto, existem custos e riscos associados a processos participativos que não devem ser ignorados e devem ser contabilizados no processo de planejamento (Tabela 5).

\begin{tabular}{|c|c|c|}
\hline & Para os cidadãos participantes & Para o governo \\
\hline \multicolumn{3}{|c|}{ Benefícios da participação pública } \\
\hline $\begin{array}{l}\text { Processo de } \\
\text { Decisão }\end{array}$ & $\begin{array}{l}\text { - Educação (aprender do governo e } \\
\text { informá-lo) } \\
\text { - } \text { Persuadir e esclarecer o governo } \\
\text { - Ganhar habilidade para uma } \\
\text { cidadania ativista } \\
\text { - Romper impasses, obter resultados } \\
\text { - Ganhar algum controle sobre os } \\
\text { processos de decisão }\end{array}$ & $\begin{array}{l}\text { - Educação (aprender dos cidadãos e } \\
\text { informá-los) } \\
\text { - } \quad \text { Persuadir cidadãos, ganhar confiança } \\
\text { e reduzir ansiedade ou tensões } \\
\text { - } \text { Formar alianças estratégicas } \\
\text { - Obter legitimidade para as ações } \\
\text { - Romper impasses, obter resultados } \\
\text { - } \text { Evitar custos de litígio } \\
\text { - Melhores políticas e decisões }\end{array}$ \\
\hline \multicolumn{3}{|c|}{ Riscos/desvantagens da participação pública } \\
\hline $\begin{array}{l}\text { Processo de } \\
\text { Decisão }\end{array}$ & $\begin{array}{l}\text { - Consome tempo (e por vezes torna- } \\
\text { se desmotivante) } \\
\text { - Sem sentido se as decisões forem } \\
\text { ignoradas } \\
\text { - } \quad \text { Representação enganosa } \\
\text { - } \\
\text { Perda de legitimidade para se } \\
\text { oporem a decisões não desejadas }\end{array}$ & $\begin{array}{l}\text { - Consome tempo } \\
\text { - Custoso } \\
\text { - Pode ter o efeito contrário ao } \\
\text { desejado e criar mais hostilidade com } \\
\text { o governo }\end{array}$ \\
\hline Resultados & $\begin{array}{l}\text { Risco de a decisão ser fortemente } \\
\text { influenciada por grupos de interesse } \\
\text { opostos }\end{array}$ & $\begin{array}{l}\text { - Perda de controle na tomada de } \\
\text { decisão } \\
\text { - Possibilidade de tomar más decisões } \\
\text { que são politicamente impossíveis de } \\
\text { ignorar }\end{array}$ \\
\hline
\end{tabular}

Tabela 5 - Vantagens e desvantagens da participação pública nos processos de tomada de decisão governamentais (Adaptado de Santos et al, 2006). 
Como conclusão, fica claro que apesar da participação do público no processo de gerenciamento não ser totalmente desprovida de riscos, ela é fundamental para o sucesso da $\mathrm{GCl}$, pois permite que se obtenha a aceitação social necessária para que as decisões tomadas no âmbito deste processo possam ser devidamente implementadas e cumpridas (Cicin-Sain \& Knecht, 1998).

\subsubsection{Funções e Procedimentos}

A GCl pretende ser um meio para lidar com várias questões relacionadas com os padrões gerais de uso das zonas costeiras, a integridade dos ecossistemas litorais e a proteção dos recursos costeiros e marinhos, assim como das comunidades costeiras. As suas funções estão, portanto, principalmente ligadas à gestão espacial destas áreas e das interações geradas da sua utilização, como analisado por Cicin-Sain e Knecht (1998) (Tabela 6).

\begin{tabular}{|c|c|}
\hline Funções & Objetivos \\
\hline Planejamento de Área & $\begin{array}{l}\text { Planejar usos atuais e futuros de áreas costeiras e marinhas } \\
\text { segundo uma visão a longo-prazo. }\end{array}$ \\
\hline Promoção de Desenvolvimento Econômico & Promover a utilização adequada de áreas costeiras e marinhas. \\
\hline Proteção de Recursos & $\begin{array}{l}\text { Proteger a base ecológica das áreas costeiras e marinhas; } \\
\text { Preservar a biodiversidade; Assegurar a sustentabilidade dos } \\
\text { usos. }\end{array}$ \\
\hline Resolução de Conflitos & $\begin{array}{l}\text { Identificar, harmonizar e compatibilizar usos existentes e } \\
\text { potenciais. }\end{array}$ \\
\hline Proteção da Segurança Pública & $\begin{array}{l}\text { Garantir a segurança pública em áreas costeiras e marinhas de } \\
\text { risco a desastres naturais e/ou induzidos pelo Homem. }\end{array}$ \\
\hline Gestão de Áreas Públicas & $\begin{array}{l}\text { Promover a gestão correta de áreas de domínio público e dos } \\
\text { recursos litorais, assegurando um retorno econômico adequado } \\
\text { ao público. }\end{array}$ \\
\hline
\end{tabular}

Tabela 6 - Principais funções da GCI (Adaptado de Cicin-Sain \& Knecht, 1998).

Quanto aos seus procedimentos, atualmente é bem aceito tanto na literatura como na prática (GESAMP, 1996; Olsen et al., 1999; Sorensen, 2002) que o progresso do esforço de $\mathrm{GCl}$ pode ser descrito como um ciclo de desenvolvimento 
de um projeto ou de uma política, cujas características são iguais às de outros processos institucionais. Este ciclo é composto por 5 etapas que consistem (1) em identificar e avaliar as questões costeiras nacionais, regionais ou locais, (2) preparar o programa ou plano de $\mathrm{GCl}$, (3) adotar formalmente o plano garantindo seu financiamento, (4) implementá-lo e (5) fazer uma avaliação do processo e resultados obtidos.

O processo de $\mathrm{GCl}$ é, portanto, constituído por um conjunto de tarefas que se enquadram de acordo com cada uma das etapas do seu ciclo de evolução, como descrito na Tabela 7. Bower \& Turner (1998) acrescentam ainda que a concretização destas ações não está restrita à ação governamental, podendo ser efetuadas tanto por entidades públicas como privadas.

\begin{tabular}{|c|c|}
\hline Fases & Ações Prioritárias \\
\hline $\begin{array}{l}\text { Fase 1: } \\
\text { Identificação e } \\
\text { Avaliação dos } \\
\text { Assuntos Chave }\end{array}$ & $\begin{array}{l}\text { - Identificar e avaliar os principais assuntos ambientais, sociais e institucionais e suas implicações. } \\
\text { - Identificar os principais atores (governamentais e não governamentais) e seus respectivos interesses. } \\
\text { - Verificar as lideranças governamentais e não-governamentais sobre os assuntos selecionados. } \\
\text { - Selecionar os assuntos sobre os quais a iniciativa de gerenciamento enfocará os esforços. } \\
\text { - Definir as metas do gerenciamento costeiro integrado. }\end{array}$ \\
\hline $\begin{array}{l}\text { Fase 2: } \\
\text { Preparação do } \\
\text { Programa }\end{array}$ & $\begin{array}{l}\text { - Realizar pesquisas científicas direcionadas às questões gerenciais identificadas como prioritárias. } \\
\text { - } \text { Rocumentar as condições atuais que servirão de linha de base. } \\
\text { - } \text { processo de planeamento. } \\
\text { - } \text { Preparar o plano de gerenciamento e a estrutura institucional sobre as quais será implementado. } \\
\text { - } \text { Planiar o desenvolvimento da capacidade técnica e institucional necessárias para a implementaçãão. } \\
\text { - Testar estratégias de implemeira. }\end{array}$ \\
\hline $\begin{array}{l}\text { Fase 3: } \\
\text { Adoção Formal } \\
\text { e Financiamento }\end{array}$ & $\begin{array}{l}\text { - Obter a aprovação governamental da proposta. } \\
\text { - Implementar o marco institucional básico do processo de Gerenciamento Costeiro Integrado e obter } \\
\text { o respaldo governamental para os diversos arranjos institucionais. } \\
\text { - Obter os fundos necessários para a implementação do programa. }\end{array}$ \\
\hline $\begin{array}{l}\text { Fase 4: } \\
\text { Implementação }\end{array}$ & $\begin{array}{l}\text { - Modificar as estratégias do programa conforme seja necessário. } \\
\text { - } \text { Promover o cumprimento das políticas e estratégias do programa. } \\
\text { - } \text { Implementar mecanismos de integração e cooperação interinstitucional. } \\
\text { - } \text { Fortalecer a capacidade gerencial, técnica e de gerenciamento financeiro do programa. } \\
\text { - Assegurar a construção e manutenção da infra-estrutura física. } \\
\text { - Alimentar a participação aberta de quem respalda o programa. } \\
\text { - Implementar procedimentos da resolução dos conflitos. } \\
\text { - } \text { Alimentar o apoio político de maneira a manter o programa entre as prioridades da agenda pública. }\end{array}$ \\
\hline $\begin{array}{l}\text { Fase 5: } \\
\text { Avaliação }\end{array}$ & $\begin{array}{l}\text { - Determinar os impactos do programa nas questões gerenciais que estão sendo tratadas. } \\
\text { - Adaptar o programa de acordo com a experiência obtida, bem como às novas condições ambientais, } \\
\text { políticas e sociais. }\end{array}$ \\
\hline
\end{tabular}

Tabela 7 - Ações prioritárias associadas a etapas do ciclo de GCI

(Adaptado de Olsen et al, 1999). 
A experiência global e regional demonstrou que os projetos de $\mathrm{GCl}$ amadurecem completando sucessivos ciclos de gerenciamento, sendo que um ciclo costuma levar de 8 a 15 anos para ser executado em escala nacional, tempo este que pode ser reduzido até a metade quando considerando projetos locais direcionados, por exemplo, a uma baía ou área urbana. Cada ciclo é geralmente denominado "geração" e costuma começar por focar alguns assuntos mais urgentes, normalmente confinados a uma certa área geográfica. À medida que se vai ganhando conhecimento e experiência nos sucessivos ciclos, a escala geográfica pode aumentar e novas questões mais complexas podem ser abordadas (Figura 2). No entanto, é possível que seja necessário completar mais do que um ciclo para que se consiga concretizar todas as etapas e aumentar o espectro de ação (Olsen et al, 2003).

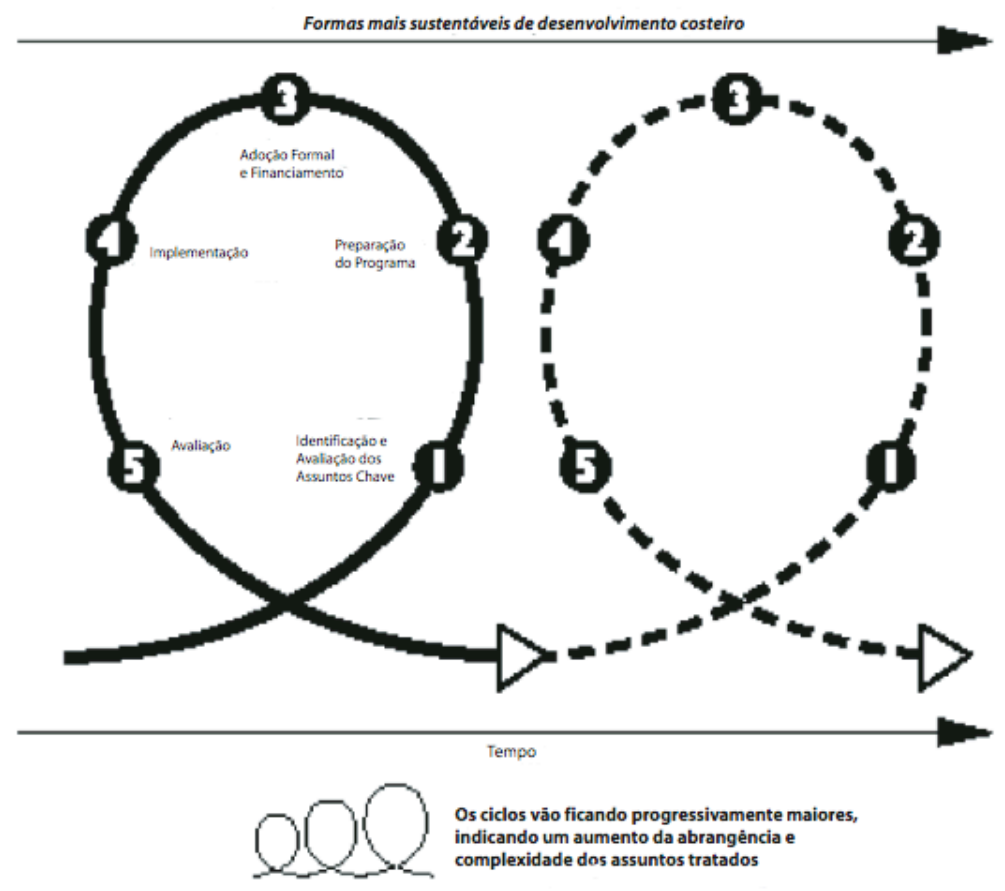

Figura 2 - Etapas e evolução do processo de GCI (Modificado de Olsen et al, 1999).

A GCl é, portanto, um processo iterativo, que vai se adaptando e sofrendo redefinições ao longo do tempo à medida que as questões que estão sendo tratadas evoluem. 


\subsubsection{Fatores determinantes para uma implementação bem sucedida de GCI}

Apesar de existir esta concordância quanto aos objetivos e princípios do processo de $\mathrm{GCl}$, a experiência tem demonstrado que certos fatores são fundamentais para que o gerenciamento costeiro integrado seja bem sucedido e que se não forem considerados desde o início, poderão comprometer a eficácia do processo na promoção da sustentabilidade das zonas costeiras.

Inicialmente, é preciso ter em conta que a natureza e a estrutura de um programa de $\mathrm{GCl}$ irá depender muito do contexto físico, socioeconômico, cultural e político no qual vai incidir, pois as variáveis que mais importam para a resolução das questões costeiras podem mudar muito de país para país, ou mesmo de região para região. Este terá, portanto, de ser adaptado à realidade e necessidades da área onde vai incidir (Cicin-Sain \& Knecht, 1998).

As características do sistema de governança serão, pois, igualmente fundamentais para o progresso e sucesso de um programa de GCl. São necessárias políticas bem definidas, legislação adequada e mecanismos de coordenação que permitam o desenvolvimento de programas desta natureza, assim como instituições descentralizadas e robustas que assegurem, por um lado, uma distribuição justa e balançeada dos benefícios obtidos pela $\mathrm{GCl}$ e, por outro lado, que tenham mecanismos de resolução de conflitos eficazes para lidar com as tensões inevitáveis de uso e ocupação das zonas costeiras (Cicin-Sain \& Knecht, 1998; Christie et al, 2005). É, portanto, essencial que a complexidade das questões tratadas pela $\mathrm{GCl}$ num dado momento seja adaptada à capacidade das instituições envolvidas (Olsen, 2002).

Todavia, uma governança adequada para lidar com as questões costeiras e capaz de assegurar um processo de $\mathrm{GCl}$, só poderá existir se o público afetado estiver envolvido ativamente no processo. A participação dos stakeholders desde o início das discussões e na elaboração do programa vai garantir que o conhecimento local e as aspirações do público sejam incorporadas neste, de tal modo que as questões focadas e os objetivos traçados sejam adequados à realidade. Isto fará com que os benefícios obtidos correspondam às expectativas da população, garantindo assim uma adesão da sociedade ao programa, vital para o seu sucesso e continuação (Cicin-Sain \& Knecht, 1998; Olsen et al, 1998; Christie et al, 2005). 
O envolvimento do público passa não só por uma participação no processo de tomada de decisão, mas também por uma adequada informação e muitas vezes educação, pois as causas subjacentes do estado atual das zonas costeiras são complexas e muitas vezes incompreendidas pelo público e pelos tomadores de decisão. Sem esse conhecimento, a gravidade da situação nunca será tratada adequadamente, nem tão pouco criará uma mobilização por parte da sociedade para a resolução dos problemas. De resto, sem esta mobilização, a vontade política para tomar decisões geralmente controversas e com algum custo político dificilmente existirá (Tobey \& Volk, 2002; Christie et al, 2005)

A correta informação do poder público é também essencial para derrubar barreiras típicas a iniciativas no setor público tais como inércia burocrática, desconfiança, oposição ideológica ou oposição devida a interesses econômicos (Cicin-Sain \& Knecht, 1998).

Como resumo, apresenta-se a síntese elaborada por Stojanovic et al (2004) com base na revisão de várias iniciativas, que propôs um conjunto de fatores importantes para uma implementação com sucesso da GCl (Figura 3).

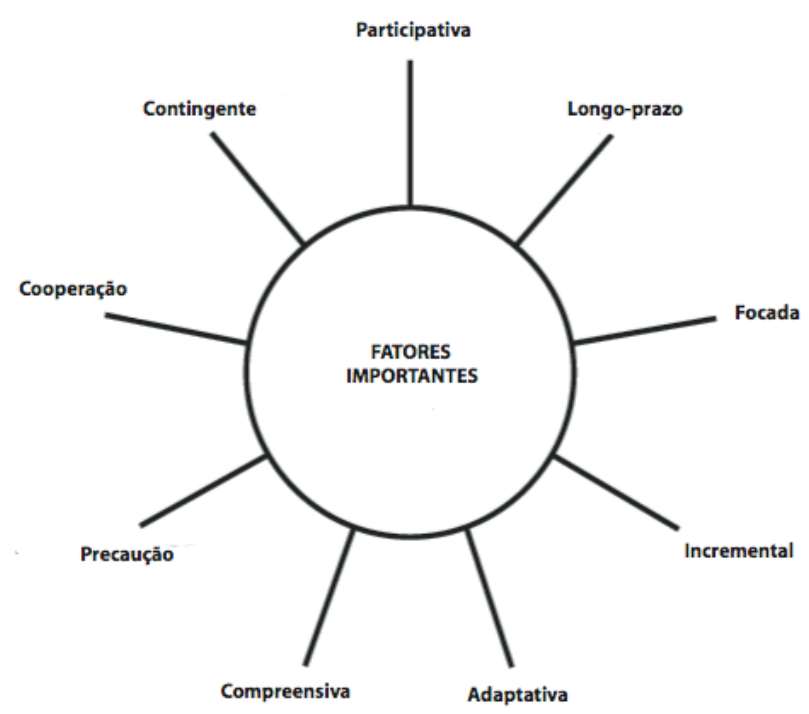

Figura 3 - Fatores importantes para o sucesso da GCI

(Modificado de Stojanovic et al, 2004) 


\subsubsection{A importância de projetos piloto para o processo de GCI}

Após a CNUMAD, assistiu-se a uma proliferação de iniciativas de $\mathrm{GCl}$ no mundo, suportadas em grande parte por importantes investimentos com origem em doações multi e bilaterais e de agências internacionais de assistência. Esses investimentos tomaram a forma de projetos piloto e foram direcionados, principalmente, a países em desenvolvimento na América Latina, África e na região Asio-Pacífico que não tinham programas de gestão costeira estabelecidos ou então, estes se encontravam apenas esboçados e sem grande concretização.

Estes projetos piloto com financiamento externo permitiram que se testassem diferentes métodos e abordagens sob várias condições e que se os adaptasse e modificasse de acordo com as condições e necessidades locais. Por conseguinte, o desenvolvimento destes projetos permitiu que se aferisse as condições institucionais, políticas, culturais e ambientais locais, assim como identificar as questões prioritárias, de maneira a que se pudesse tomar decisões efetivas para assegurar um desenvolvimento sustentável dessas zonas costeiras.

Ressalta-se que muitos desses projetos piloto acabaram por não ter a devida continuidade após o financiamento externo ter sido retirado. No entanto, isso se deve, sobretudo, a algumas falhas de planejamento relacionadas com fatores como arranjos institucionais e mecanismos de financiamento, que não tem permitido que o trabalho realizado durante os projetos tenha obtido a devida sustentabilidade (Tobey \& Volk, 2002; White et al, 2005). Isso não retira a importância e validade que os projetos pilotos têm para o desenvolvimento da $\mathrm{GCl}$, apenas reitera a necessidade que existe de avaliação como meio de corrigir as falhas. Esses projetos piloto foram assim de fato o principal meio pelo qual os governos de muitos países em desenvolvimento traduziram suas aspirações relativas ao gerenciamento costeiro em programas concretos de ação (Olsen \& Christie, 2000; Tobey \& Volk, 2002).

Por outro lado, como visto anteriormente, os programas de $\mathrm{GCl}$ necessitam ser adaptados às condições locais, o que pode acontecer até mesmo ao nível do próprio país, sobretudo em países onde existem grandes contrastes socioeconômicos. Esses países geralmente têm pouca capacidade para lidar com os problemas das zonas costeiras com base numa ação concertada de nível nacional (FAO, 1998), tendo que essa iniciativa ser tomada a maioria das vezes a nível local. 
Assim, os projetos piloto, se organizados corretamente, podem servir igualmente de campo de experiência para testar as capacidades domésticas das abordagens técnicas, institucionais e organizacionais para gerir as zonas costeiras e assim oferecer importantes subsídios para a elaboração ou avaliação de um programa de GCl de âmbito nacional (Sorensen, 1997; FAO, 1998).

O desenvolvimento de projetos piloto locais em áreas chave é, portanto, reconhecido como uma estratégia efetiva para acelerar o processo de aprendizagem (Sorensen, 1997), verificando-se na literatura um número crescente de publicações (ver, por exemplo, Olsen et al, 1998; Chua, 1998; Bárragan Munõz et al, 2003; White et al 2005; Pak \& Farajzadeh, 2007) que visam partilhar as experiências obtidas como resultado de projetos locais, o que tem sido fundamental para potenciar o aprendizado e extrair lições valiosas para a elaboração de novos programas de $\mathrm{GCl}$ no próprio país ou noutros locais.

\subsection{A Gestão Costeira no Brasil}

Neste capítulo é esboçada a evolução da gestão costeira no Brasil, são analisados seus principais sucessos e falhas, e avaliada suas potencialidades, de maneira a que se possa, por um lado, contextualizar este processo no âmbito da gestão costeira integrada vista anteriormente e, por outro, contextualizar igualmente o cenário atual do Brasil, para melhor entender as dificuldades e oportunidades que surgiram no desenvolvimento do caso de estudo.

\subsubsection{A Gênese da Gestão Costeira no Brasil e o Desenvolvimento das suas Bases Legais}

Os primeiros passos dados pelo Brasil no sentido de gerenciar os recursos marinhos e os espaços costeiros remontam à década de 1970, altura em que a preocupação com o meio ambiente começou a se consolidar no país (Asmus \& Kitzmann, 2004). Constituíram-se, então, em 1973 a Secretaria Especial do Meio Ambiente da Presidência da República - SEMA/PR e, em 1974, a Comissão Interministerial para os Recursos do Mar - CIRM, com o objetivo de gerar diretrizes e políticas para as suas respectivas áreas de atuação. O resultado foi a publicação, 
em 1980, da Política Nacional de Recursos do Mar (PNRM) e, em 1981, a Política Nacional do Meio Ambiente (PNMA).

O processo da gestão costeira no Brasil, propriamente dito, surgiria alguns anos mais tarde quando, em 1987, a CIRM formulou o Programa Nacional de Gerenciamento Costeiro (GERCO). Este tinha o propósito de planejar e gerenciar de forma integrada, descentralizada e participativa as atividades socioeconômicas na zona costeira, de forma a garantir a utilização sustentável dos recursos e ecossistemas costeiros por meio de medidas de controle, proteção, preservação e recuperação. Seis estados foram escolhidos na ocasião para dar início à implantação do Programa: Rio Grande do Norte, Bahia, Rio de Janeiro, São Paulo, Santa Catarina e Rio Grande do Sul.

Este processo viria a ser igualmente impulsionado pela publicação de uma nova Carta Constitucional em 1988, que passava a considerar a Zona Costeira, juntamente com a Floresta Amazônica, a Mata Atlântica, a Serra do Mar e o Pantanal, como parte do Patrimônio Nacional, representando assim uma autêntica declaração institucional de intenções (Barragán Munoz, 2001).

O GERCO foi, então, efetivado no mesmo ano através da promulgação da Lei 7.661/88 que instituiu o Plano Nacional de Gerenciamento Costeiro (PNGC) e, mais tarde, aprovado pela Resolução CIRM nº 01 de 21/11/90, constituindo a base legal para o planejamento da zona costeira brasileira. O PNGC surgiu como resultado da integração da Política Nacional para os Recursos do Mar e da Política Nacional do Meio Ambiente e estabelece os princípios, os instrumentos, as competências e a área de abrangência geográfica para a gestão da zona costeira, explicitando as atribuições de cada instância do governo. Estabeleceu-se igualmente na mesma época, através do Decreto n 96.660/88, o COGERCO - o Grupo de Coordenação do Gerenciamento Costeiro, incumbido de elaborar e atualizar o PNGC.

O detalhamento e operacionalização do PNGC foram posteriormente atualizados pela Resolução CIRM nº 05 de 03/12/97, que deu origem ao PNGC II, mas foi apenas em 2004 que todas estas ações foram regulamentadas através do Decreto $n^{\circ} 5.300$ de 7 de Dezembro de 2004. Este decreto instituiu as normas gerais do gerenciamento costeiro do País, estabelecendo as bases para a formulação de políticas, planos e programas federais, estaduais e municipais. 


\subsubsection{O Plano Nacional de Gerenciamento Costeiro}

\subsubsection{Principais Aspectos do PNGC}

O PNGC foi, portanto, instituído pela Lei $n^{\circ} 7661$ de 16 de Maio de 1988, como um conjunto de atividades e procedimentos que através de instrumentos específicos, visava "orientar a utilização racional dos recursos da zona costeira, de forma a contribuir para elevar a qualidade de vida de sua população e a proteção de seu patrimônio natural, histórico, étnico e cultural" (Artigo $2^{\circ}$ ).

O seu escopo transcendia a simples intenção de preservação ambiental, estando contempladas ações relativas aos seguintes aspectos: urbanização; ocupação e uso do solo, do subsolo e das águas; parcelamento do solo; sistema viário e de transporte; sistema de produção, transmissão e distribuição de energia; habitação e saneamento básico; turismo, recreação e lazer; patrimônio natural, histórico, étnico, cultural e paisagístico (Artigo $5^{\circ}$ ).

Outro fato importante é que ficou estabelecido que o gerenciamento costeiro é uma atividade integrada, cuja responsabilidade deve ser compartilhada por todas as esferas governamentais (federal, estadual, local), deixando claro o papel descentralizador do Plano (BRASIL, 1988).

Quanto aos instrumentos de gestão, ficaram estabelecidos no Decreto 5.300/04, além dos previstos pela Política Nacional do Meio Ambiente, (1) o Zoneamento Ecológico-Econômico - ZEEC, (2) o Sistema de Informações do Gerenciamento Costeiro - SIGERCO, (3) o Sistema de Monitoramento Ambiental da Zona Costeira - SMA-ZC, (4) o Relatório de Qualidade Ambiental da Zona Costeira - RQA-ZC, (5) o Plano de Gestão da Zona Costeira - PGZC, (6) o Plano Estadual da Gerenciamento Costeiro - PEGC, (7) o Plano Municipal de Gerenciamento Costeiro - PMGC.

Relativamente à sua estrutura institucional, o Instituto Brasileiro do Meio Ambiente e Recursos Naturais Renováveis - IBAMA, foi o responsável pela supervisão e coordenação nacional do PNGC até 1992, tendo a sua tutela passada a partir dessa data para o Ministério do Meio Ambiente - MMA. De maneira a respeitar o espírito da Constituição Nacional Brasileira e da Política Nacional do Meio Ambiente, procurou-se obter uma ação integrada e responsabilidade conjunta entre os níveis federal, estadual e local, sobretudo em questões relacionadas com 
ações de proteção ambiental e de planejamento territorial regional (Asmus \& Kitzmann, 2004; Polette \& Vieira, 2005).

Coube, então, ao governo federal a definição das principais diretrizes e procedimentos cooperativos inter-regionais; ao governo estadual o planejamento e desenvolvimento do estado, estabelecendo parcerias entre estados vizinhos para atenuar e resolver problemas comuns, assim como articular acordos entre municípios; e ao governo local regular o uso da terra, tendo responsabilidade sobre ela, assim como pelo desenvolvimento adequado das comunidades e cidades (Asmus \& Kitzmann, 2004).

O MMA, através da Secretaria de Qualidade Ambiental nos Assentamentos Humanos (SQA), dirige o GERCO em âmbito federal e coordena as ações estaduais, assim como as atividades federais intersetoriais na zona costeira. Esta coordenação é conduzida pelo Grupo de Integração do Gerenciamento Costeiro GI-GERCO, com o apoio legal da Câmara Técnica Permanente para o Gerenciamento Costeiro do CONAMA, tendo a CIRM como facilitador (Asmus \& Kitzmann, 2004).

O GI-GERCO é composto por representantes de diversos setores federais, da administração pública estadual e local relacionadas com o meio ambiente e de ONGs que compõem as representações regionais da sociedade no CONAMA. Este Grupo é ainda assessorado tecnicamente por um Sub-Grupo de Integração dos Estados, composto pelos coordenadores estaduais do GERCO (Asmus \& Kitzmann, 2004).

Ao nível dos estados, são instituídos os colegiados costeiros com a função de discutir e encaminhar políticas, planos, programas e ações destinadas à gestão costeira. Além de representantes de órgãos estaduais que atuam na região costeira, estes colegiados incluem também representantes dos municípios e da sociedade civil organizada, estando igualmente prevista no PNGC a instalação de colegiados municipais (Asmus \& Kitzmann, 2004).

\subsubsection{Evolução do PNGC}

Para se cumprir com o objetivo da implementação de uma atuação integrada e descentralizada, as primeiras iniciativas da esfera federal foram no sentido de 
prover recursos aos estados para a elaboração do zoneamento costeiro. No entanto, esta se tornou a preocupação central inicial do GERCO, pois o Zoneamento Costeiro, responsabilidade das esferas estaduais, foi considerado um pré-requisito para a viabilização dos restantes instrumentos de política ao nível estadual, sendo estes, na ocasião, os Planos de Gestão e os Programas de Monitoramento (Polette et al, 2006).

Como resultado, os primeiros anos de trabalho associados ao PNGC foram caracterizados por deficiências metodológicas orientadas por uma visão excessivamente tecnocrática e voltada para a elaboração de material cartográfico, tendo pouco contribuído para as questões de gerenciamento efetivo da área costeira (Polette \& Vieira, 2005; Barragán Munoz, 2001).

Este modus operandi, assim como outros aspectos institucionais, foram objeto de revisão durante o primeiro processo de avaliação do PNGC, em 1992. A identificação dos seus problemas, assim como o aprendizado obtido até então, levou a um aprimoramento das ações e marcou o início de uma nova fase, mais dinâmica e produtiva, que se estendeu até 1997 (Polette et al, 2006).

Durante essa fase, diversificaram-se as ações, promovendo-se a capacitação das equipes dos órgãos ambientais estaduais e estabelecendo-se parcerias e convênios para a existência de ações conjuntas intergovernamentais. Foram criados fóruns interinstitucionais de discussão e formulação de ações de planejamento costeiro, como a Câmara Técnica do Gerenciamento Costeiro no CONAMA.

Adquiriram-se, igualmente, equipamentos, instituindo-se um banco de dados georeferenciado com coordenação nacional, já no sentido de se estabelecer um sistema centralizado de informações do gerenciamento costeiro. Por último, concretizaram-se avanços conceituais e operacionais ligados à implementação dos Planos de Gestão e Programas de Monitoramento, assim como valorações econômicas e diagnósticos ambientais (Moraes, 1999 apud Polette \& Vieira, 2005).

A atualização do PNGC ocorreu em 1997 e foi conduzida pelo COGERCO que, após consultar as equipes estaduais, preparou uma nova versão do PNGC, o PNGC II, tendo sido aprovada pela Resolução CIRM nº 05/97.

O PNGC I assentou as bases metodológicas do GERCO, definindo o seu modelo institucional e seus instrumentos de gestão. Já o PNGC II procurou incorporar as experiências decorrentes da implantação do Programa, tentando melhor incluir as necessidades da sociedade e assim aperfeiçoar a sua forma de 
operação (Asmus \& Kitzmann, 2004). O novo enfoque pretendia diminuir os conflitos relativos ao uso da terra e dos recursos naturais, de maneira a obter acordos sociais que salvaguardassem a sustentabilidade do sistema costeiro (Polette \& Vieira, 2005).

Deste modo, a zona costeira foi definida como um território delimitado pelos limites políticos dos municípios litorâneos, de maneira a tornar mais operacional a sua gestão (Polette \& Vieira, 2005). O novo Plano também procurou definir melhor as atribuições do Governo Federal na implementação do GERCO (Asmus \& Kitzmann, 2004). Tal fato resultou do PNGC I representar uma visão excessivamente descentralizadora, que repassava as responsabilidades de execução das ações práticas do gerenciamento costeiro aos estados, diminuindo o campo de atuação da União (Polette \& Vieira, 2005). O PNGC II procurou não só acentuar a responsabilidade da esfera federal, mas também a dos governos municipais, assim como a da sociedade civil organizada, no Programa (Polette et al. 2006).

Quantos aos processos de zoneamento e diagnóstico, estes foram direcionados de maneira a oferecer uma representação efetiva e sintética do espaço estudado. Por outro lado, deixou-se de focar todos os esforços no sentido de completar o zoneamento, cuja atribuição exclusiva de elaboração residia na esfera estadual, para avançar na implementação dos restantes instrumentos previstos no Plano, passando os Planos de Gestão a ter maior visibilidade em todos os níveis de gestão (Polette \& Vieira, 2005; Polette et al, 2006).

Ficou igualmente reforçada no PNGC II a necessidade e importância de se estabelecerem parcerias e atividades articuladas entre órgãos governamentais. Para facilitar estas conexões interinstitucionais foi criado um fórum permanente de interlocução interinstitucional na esfera da União, o GI-GERCO - Grupo de Integração do Gerenciamento Costeiro, com a finalidade de promover a articulação das ações federais incidentes na Zona Costeira a partir da aprovação dos Planos de Ação Federal - PAF ${ }^{10}$. Fica, portanto, claro, no PNGC II, o papel da União como

${ }^{10}$ Os Planos de Ação Federal são estruturados por programas especificados em linhas de ação, que têm o objetivo de fornecer as orientações políticas gerais para a atuação do PNGC, procurando promover ações combinadas e projetos institucionais de parceria. O primeiro PAF foi implementado em 1998 e foi revisto em 2005. 
agente coordenador e articulador das diversas instâncias do Programa (Asmus \& Kitzmann, 2004; Polette et al, 2006).

Finalmente, os instrumentos básicos de gestão foram reafirmados, ficando, no entanto, mais evidente a possibilidade de utilização de outros instrumentos previstos na Política Nacional do Meio Ambiente e assim acentuar a articulação do GERCO com outras rotinas dos órgãos ambientais (Polette \& Vieira, 2005).

\subsubsection{Principais resultados obtidos desde a implementação do PNGC}

Atualmente, o Programa encontra-se operacional e com uma estrutura de implantação descentralizada, onde as responsabilidades e competências dos 3 níveis de governo estão bem definidas. Desta maneira, o PNGC encontra-se institucionalizado em todos os 17 estados costeiros, com equipes de trabalho instaladas e cujas coordenações se encontram articuladas tanto com a coordenação nacional, como com os municípios através de ações de zoneamento, planos de gestão e outras (Asmus \& Kitzmann, 2004).

As revisões e atualizações necessárias das bases legais do Programa e a existência de mecanismos que promovem a integração interinstitucional e intersetorial têm sido asseguradas pela União, como visto anteriormente, de acordo com o seu papel coordenador e supervisor. O MMA, em parceria com universidades e centros de pesquisa, tem tido igualmente um papel importante na elaboração de documentos que pretendem subsidiar o GERCO, através da construção de um importante arcabouço teórico para a gestão costeira e promovido a capacitação de gestores estaduais e locais nesse sentido. Tem também procurado compatibilizar as ações do governo que incidem na zona costeira através da implantação do Plano de Ação Federal.

É de salientar, finalmente, um projeto da responsabilidade do MMA em parceria com o Ministério do Planejamento - o projeto Orla, cujo desenho institucional se orienta no sentido da descentralização de ações de planejamento e gestão da orla da esfera federal para a do município. Este projeto foi idealizado para fazer frente às dificuldades do governo central para fiscalizar a ocupação e o uso indevido dos terrenos da União na Orla Marítima (pertencentes à Marinha).

O seu objetivo é aproximar a política ambiental com a patrimonial de maneira a promover uma gestão integrada da orla através do ordenamento do uso e 
ocupação desse espaço, ao mesmo tempo em que potencializa o papel do município na gestão costeira. Foi, portanto, inserido no âmbito do GI-GERCO como parte das ações prioritárias do PAF de 1998.

Desde a sua implantação em 2001, o projeto Orla capacitou 58 municípios em 14 estados, tendo sido estabelecidos Planos de Intervenção ${ }^{11}$ em cada um destes municípios após uma ação conjunta entre os gestores locais, universidades, sociedade civil organizada e entidades privadas.

As principais ações e resultados obtidos pelo MMA no âmbito do GERCO encontram-se sumarizados na Tabela 8.

\section{Ações e Resultados GERCo}

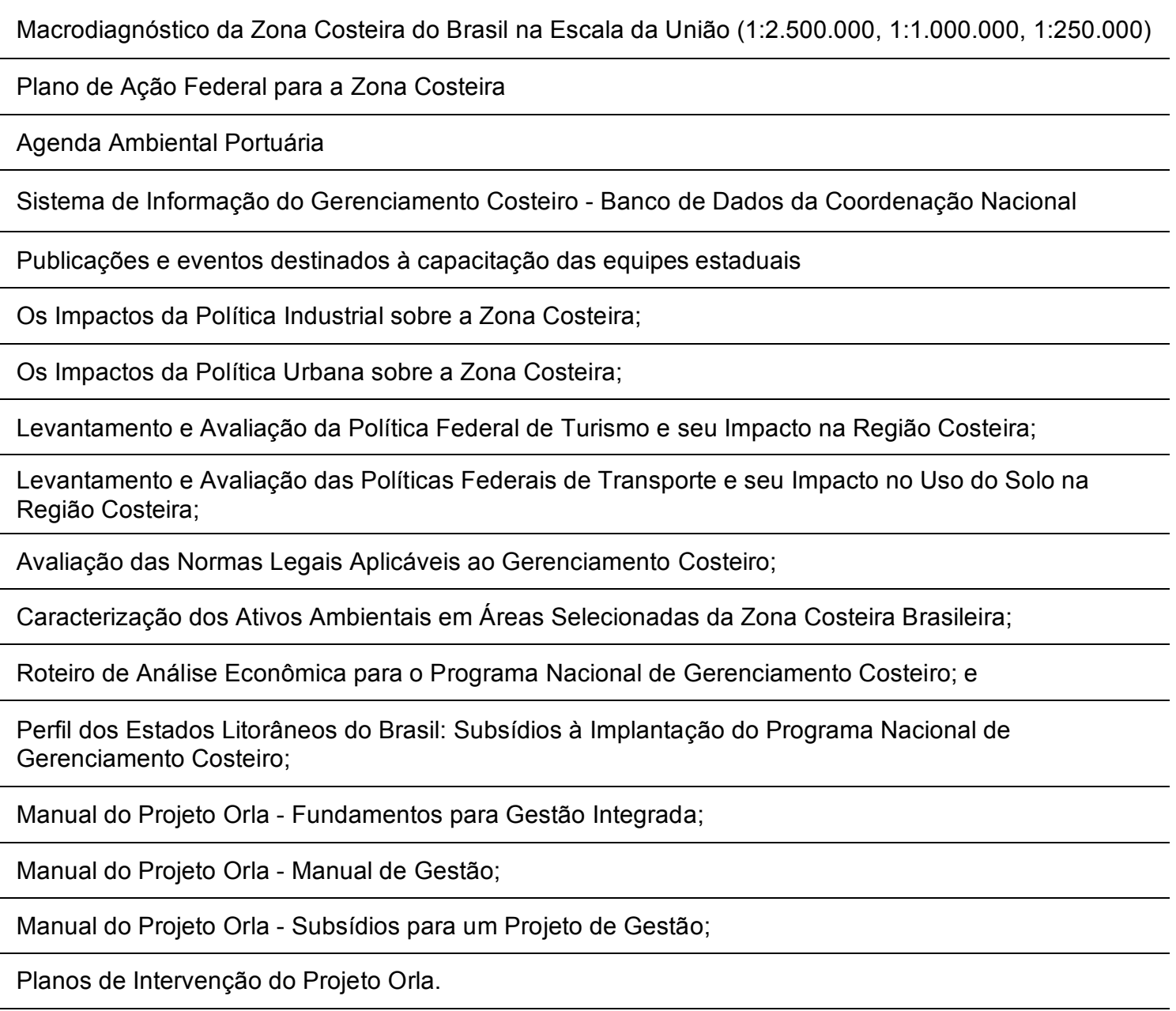

Tabela 8 - Principais ações e resultados do MMA no âmbito do GERCO

(Fonte: www.mma.gov.br)

${ }^{11}$ O Plano de Intervenção é o documento resultante do processo de capacitação que apresenta as diretrizes para a gestão da orla local a partir do diagnóstico ambiental e socioeconômico e da classificação e elaboração do cenário de uso desejado, a ser legitimado por meio de consulta pública. 
Ao nível dos estados, verifica-se que todos os estados costeiros já possuem diagnósticos socioambientais das suas áreas costeiras. O zoneamento ecológicoeconômico já foi efetuado em mais de $40 \%$ do território que abrange a Zona Costeira e já foram elaborados planos de gestão em 15 dos 17 estados litorâneos (Tabela 9).

ESTADO

RESULTADOS OBTIDOS

\begin{tabular}{|c|c|}
\hline AMAPÁ & $\begin{array}{l}\text { Diagnóstico preliminar - todo o litoral }\left(69.842 \mathrm{~km}^{2}\right) \\
\text { Plano de desenvolvimento sustentável } \\
\text { Lei estadual de gerenciamento costeiro }\end{array}$ \\
\hline PARÁ & Diagnóstico - Costa Atlântica do Salgado Paraense $(15.200$ km²) \\
\hline MARANHÃO & $\begin{array}{l}\text { Zoneamento - Golfão Maranhense }\left(7.570 \mathrm{~km}^{2}\right) \\
\text { Plano de manejo do Parcel de Manoel Luís } \\
\text { Plano de contingência da baía de São Marcos } \\
\text { Setor de geoprocessamento }\end{array}$ \\
\hline PIAUÍ & Diagnóstico preliminar - todo o litoral $\left(4.633 \mathrm{Km}^{2}\right)$ \\
\hline CEARÁ & $\begin{array}{l}\text { Zoneamento - litoral leste }\left(4.684 \mathrm{~km}^{2}\right) \\
\text { Zoneamento - litoral oeste }\left(3.848 \mathrm{~km}^{2}\right) \\
\text { Plano de gestão setor leste } \\
\text { Plano gestão do setor oeste }\end{array}$ \\
\hline $\begin{array}{l}\text { RIO GRANDE DO } \\
\text { NORTE }\end{array}$ & $\begin{array}{l}\text { Zoneamento - litoral oriental }\left(4.932 \mathrm{~km}^{2}\right) \\
\text { Plano estadual de gestão costeira } \\
\text { Projeto de manejo (dunas) } \\
\text { Projeto de fiscalização integrada (ação zona costeira) } \\
\text { Lei estadual de gerenciamento costeiro } \\
\text { Setor de geoprocessamento }\end{array}$ \\
\hline PARAÍBA & $\begin{array}{l}\text { Diagnóstico - litoral norte }\left(1.100 \mathrm{~km}^{2}\right) \\
\text { Zoneamento - litoral sul }\left(1.539 \mathrm{~km}^{2}\right) \\
\text { Plano de gestão do município de Cabedelo } \\
\text { Plano de gestão da região metropolitana de João Pessoa } \\
\text { Parâmetros de licenciamento ambiental litorâneo } \\
\text { Minuta de anteprojeto de lei sobre o PEGC }\end{array}$ \\
\hline PERNAMBUCO & $\begin{array}{l}\text { Zoneamento preliminar litoral sul }\left(2.097 \mathrm{~km}^{2}\right) \text { / Zoneamento da APA de } \\
\text { Guadalupe } \\
\text { Plano de gestão do litoral sul } \\
\text { Ação intermunicipal de gestão de resíduos sólidos urbanos (movimento } \\
\text { Onda Limpa) } \\
\text { APA dos corais }\end{array}$ \\
\hline ALAGOAS & $\begin{array}{l}\text { Zoneamento - litoral norte }\left(578 \mathrm{~km}^{2}\right) \\
\text { Plano de gestão do litoral norte } \\
\text { Plano de gestão do complexo estuarino lagunar Mundaú-Manguaba } \\
\text { APA dos corais }\end{array}$ \\
\hline SERGIPE & $\begin{array}{l}\text { Zoneamento - litoral sul }\left(2.496 \mathrm{~km}^{2}\right) \\
\text { Plano Estadual de Gestão Costeira }\end{array}$ \\
\hline
\end{tabular}




\begin{tabular}{|c|c|}
\hline BAHIA & $\begin{array}{l}\text { Zoneamento - litoral norte }\left(7.890 \mathrm{~km}^{2}\right) \\
\text { Zoneamento - Salvador / Baía de Todos os Santos }\left(4.835 \mathrm{~km}^{2}\right) \\
\text { Zoneamento - litoral sul }\left(28.884 \mathrm{~km}^{2}\right) \\
\text { Anteprojeto de lei do Plano Estadual de Gerenciamento Costeiro (no } \\
\text { âmbito do executivo) } \\
\text { Setor de geoprocessamento }\end{array}$ \\
\hline ESPÍRITO SANTO & $\begin{array}{l}\text { Diagnóstico e zoneamento - litoral norte }\left(4.248 \mathrm{~km}^{2}\right) \\
\text { Diagnóstico e zoneamento - litoral Centro/Grande Vitória }\left(1.450 \mathrm{~km}^{2}\right) \\
\text { Diagnóstico e zoneamento - litoral sul }\left(894 \mathrm{~km}^{2}\right) \\
\text { Plano de gestão do litoral norte } \\
\text { Setor de geoprocessamento }\end{array}$ \\
\hline RIO DE JANEIRO & $\begin{array}{l}\text { Diagnóstico - região dos Lagos }\left(2.695 \mathrm{~km}^{2}\right) \\
\text { Macroplano de gestão (Sepetiba e llha Grande) } \\
\text { Plano estadual de gestão costeira } \\
\text { Setor de geoprocessamento }\end{array}$ \\
\hline SÃO PAULO & $\begin{array}{l}\text { Zoneamento - litoral norte }\left(2.474 \mathrm{~km}^{2}\right) \\
\text { Zoneamento - Vale do Ribeira }\left(13.243 \mathrm{~km}^{2}\right) \\
\text { Diagnóstico - Complexo estuarino lagunar lguape, Cananéia e llha } \\
\text { Comprida }\left(3.287 \mathrm{~km}^{2}\right) \\
\text { Plano estadual de gestão costeira } \\
\text { Plano de gestão da APA de Cananéia e Peruíbe } \\
\text { Subsídios a planos diretores municipais } \\
\text { Lei estadual (na assembléia legislativa) } \\
\text { Normas para instalação de marinas } \\
\text { Setor de geoprocessamento }\end{array}$ \\
\hline PARANÁ & $\begin{array}{l}\text { Zoneamento - todo o litoral }\left(5.594 \mathrm{~km}^{2}\right) \\
\text { Plano estadual de gestão costeira } \\
\text { Plano de gestão da APA de Guaraqueçaba } \\
\text { Plano de gestão da llha do Mel } \\
\text { Lei de ordenamento do uso do solo e do litoral (aprovada) }\end{array}$ \\
\hline SANTA CATARINA & $\begin{array}{l}\text { Diagnóstico concluído - litoral norte }\left(4.051 \mathrm{~km}^{2}\right) \\
\text { Zoneamento - litoral centro }\left(1832,3 \mathrm{~km}^{2}\right) \\
\text { Zoneamento - litoral sul }\left(3497 \mathrm{~km}^{2}\right) \\
\text { Anteprojeto de lei estadual } \\
\text { Plano estadual de gestão costeira } \\
\text { Setor de geoprocessamento }\end{array}$ \\
\hline RIO GRANDE DO SUL & $\begin{array}{l}\text { Zoneamento - litoral norte }\left(3.700 \mathrm{~km}^{2}\right) \\
\text { Plano de gestão de resíduos sólidos } \\
\text { Enquadramento de recursos hídricos } \\
\text { Setor de geoprocessamento }\end{array}$ \\
\hline
\end{tabular}

Tabela 9 - Resumo dos resultados obtidos pelos 17 estados costeiros brasileiros no âmbito do GERCO (Fonte: www.mma.gov.br)

Outras ações no contexto da implantação do PNGC também já foram iniciadas pelos estados donde se destacam: o monitoramento ambiental; o estabelecimento de diretrizes para o licenciamento ambiental na zona costeira; o 
apoio à elaboração de Planos Diretores que internalizem as diretrizes estabelecidas nos zoneamentos costeiros e o fornecimento de subsídios para a criação de unidades de conservação (Asmus \& Kitzmann, 2004).

Apesar do ritmo e resultado dos trabalhos em cada estado ser diferente, geralmente reflexo das desigualdades regionais, estes têm colaborado ativamente para a implementação do GERCO.

A operacionalização do Sistema de Informações de Gerenciamento Costeiro SIGERCO, com núcleos nos estados e na Coordenação Nacional, foi outro avanço considerável. A integração dos resultados e dados relativos aos esforços efetuados pelos executores do gerenciamento costeiro numa base de dados central possibilita uma maior distribuição e acesso às informações. O SIGERCO representa, portanto, um instrumento básico de apoio que atualmente cumpre as funções de armazenar informações espacializadas de imagens e de caráter gerencial para subsídio técnico aos Estados e Municípios, mas devendo, no futuro, passar a constituir uma rede online (Asmus et al, 2006).

Por último, considera-se necessário fazer duas considerações sobre eventos recentes que aconteceram ao nível federal e que poderão vir a influir sobre o GERCO. A primeira está relacionada com o fato do Ministério do Meio Ambiente ter sido recentemente alvo de uma reestruturação (Decreto $n^{\circ}$ 6.101/2007), da qual resultou a criação de quatro novas secretarias e o desmembramento do IBAMA em duas instituições: uma que guardou o mesmo nome e outra denominada de Instituto Chico-Mendes de Conservação da Biodiversidade. O IBAMA permanecerá com a responsabilidade pela autorização, fiscalização e licenciamento ambiental, mas passará a transferir as tarefas de propor, implantar, gerir, proteger, fiscalizar e monitorar todas as unidades de conservação existentes no país para o Instituto Chico Mendes. Como esta reestruturação é recente, ainda não é possível aferir se esta terá impactos positivos, negativos ou mesmo nenhum no processo de gerenciamento costeiro do país.

A segunda questão é referente às discussões que já estão em andamento no âmbito do Conselho Nacional dos Recursos Hídricos - $\mathrm{CNRH}$, sobre uma possível integração da gestão das Bacias Hidrográficas com o gerenciamento costeiro. Já foi inclusive elaborada uma proposta de resolução pela Câmara Técnica de Integração da Gestão das Bacias Hidrográficas e dos Sistemas Estuarinos e Zonas Costeiras (CTCOST) que estabelece diretrizes adicionais que devem ser incluídas nos planos 
de recursos hídricos das regiões que contenham trechos da zona costeira. Esta já foi submetida para aprovação pelo CNRH e será avaliada durante este ano de 2008. Tudo indica, portanto, que esta será brevemente uma realidade, o que irá melhorar significativamente a gestão das zonas costeiras, uma vez que grande parte das pressões nestas áreas é originada em terra, nas bacias de contribuição adjacentes.

Como conclusão, o PNGC, tal como previsto na Lei 7.661/88, tem sido alvo, ao longo dos últimos 20 anos, de várias avaliações e ajustes que foram redefinindo os seus contornos, numa tentativa de melhor adaptá-lo às condições e necessidades reais relativas à gestão das questões costeiras.

O Gerenciamento Costeiro começou com um primeiro Plano pouco específico e pouco abrangente, que não esclarecia adequadamente os seus objetivos, áreas de atuação e métodos. O PNGC II procurou preencher estas lacunas. Conseqüentemente, manteve os objetivos e princípios fundamentais adotados anteriormente, tal como o modelo institucional descentralizador e de ação cooperativa entre as várias esferas do governo. No entanto, estabeleceu diretrizes diferenciadas quanto à explicitação dos objetivos do Programa, às atividades da coordenação e ao roteiro metodológico recomendado até então, o que possibilitou a concretização de importantes avanços na implementação do GERCO.

Porém, são igualmente apontadas por diversos autores, várias falhas e insuficiências ao Programa, pelo que se torna necessário fazer uma descrição da avaliação que tem sido feita à sua implementação.

\subsubsection{Retrato do processo de implementação do GERCO}

Ainda existem poucas publicações orientadas para a avaliação do processo de implementação do GERCO no Brasil, particularmente por parte de instituições de pesquisa e desenvolvimento, o que demonstra desde logo a falta de envolvimento no processo da massa crítica ligada ao gerenciamento costeiro, localizada nos programas universitários de Oceanografia, Ecologia Costeira e Gestão Ambiental (Asmus \& Kitzmann, 2004). No entanto, apesar desta deficiência, as conclusões obtidas por trabalhos recentes realizados por pesquisadores sem vínculo oficial com o GERCO são concordantes quanto aos principais pontos positivos e negativos 
resultantes da implementação do Programa e cuja síntese é apresentada em seguida.

Para tal, utilizaram-se os trabalhos de Bárragan Munoz (2001), Asmus \& Kitzmann (2004), Polette \& Vieira (2005) e Polette et al. (2008a; 2008b) que analisam o GERCO desde a sua implementação e sob várias perspectivas. Apesar de existirem outros autores que contribuíram igualmente para a análise do gerenciamento costeiro no Brasil, optou-se por usar apenas estes por serem os mais atualizados e abrangentes, de maneira a se obter uma síntese da situação atual e também, porque esses autores já são alvo de revisão nos trabalhos analisados.

\subsubsection{Principais Obstáculos}

Os obstáculos identificados à implementação efetiva do Programa podem ser essencialmente agrupados em quatro grupos: político-institucionais, técnicoadministrativos, financeiros e sócio-culturais.

\section{- Obstáculos político-institucionais}

A falta de apoio político que o Programa tem tido ao longo destes anos tem sido um dos destaques principais por parte dos diversos autores, sobretudo no que diz respeito à esfera municipal, onde as eleições de representantes estão muitas vezes atreladas a interesses lobistas relativos às questões locais. Assim, verifica-se uma falta de comprometimento com o GERCO por parte dos municípios, pois o programa é visto como uma ameaça que vem limitar a "liberdade" existente até agora quanto ao uso e ocupação da zona costeira, algo que tem sido majoritariamente orientado por interesses econômicos.

Por outro lado, o GERCO é um processo de longo prazo, cujos resultados em termos de benefícios sociais demoram a aparecer ou mesmo são pouco evidentes para a sociedade. Por exemplo, conseguir impedir um empreendimento impactante numa dada área não gera uma melhoria imediata de condição à sociedade, apenas contribui para a sua manutenção, logo, não tem atratividade política para decisores que são avaliados com base nos resultados alcançados durante o seu mandato, ou seja, a curto/médio prazo. 
A falta de engajamento político em todos os níveis acaba também por resultar numa falta de sintonia entre as diferentes escalas político-administrativas. Isto faz com que as políticas públicas incidentes sobre a zona costeira não estejam compatibilizadas, sendo freqüente que as políticas federais sejam desvinculadas das realidades locais.

A centralização das decisões cruciais na esfera federal, atrelada a uma falta de clareza na definição das competências e atribuições dos órgãos governamentais envolvidos, e a fragmentação institucional têm também sido importantes obstáculos ao avanço dos trabalhos. Apesar da existência de fóruns legítimos de articulação e diálogo dos diversos atores e usuários costeiros, o número de parcerias efetivas entre agências responsáveis pelo GERCO ainda é reduzido.

\section{- Obstáculos técnico-administrativos}

Os diferentes autores que avaliaram a questão do apontam claramente para uma insuficiência na capacitação e composição das equipes técnicas estaduais e municipais que implantaram o Programa, não tendo, inclusive especialistas nelas incorporados. Os especialistas costumam ser consultados apenas esporadicamente (oriundos de consultoras ou de universidades) e, sobretudo, para questões específicas, como na elaboração do zoneamento. Além disso, os recursos humanos existentes para implantar o Programa não eram em número suficiente e sofriam acúmulo de funções, o que incapacitava uma boa execução do seu trabalho. A base de informações é também geralmente deficitária, sobretudo nos estados do Norte/Nordeste.

Outro aspecto importante é a falta de parcerias entre instituições de pesquisa e universidades com os órgãos de gestão. A sua contribuição tem se restringido basicamente à prestação de consultorias técnicas, o que significa que o seu potencial técnico-científico está sendo sub-aproveitado. Isto é ainda mais grave considerando que são inúmeros os projetos de pesquisa e ensino que estão diretamente relacionados com os instrumentos preconizados pelo PNGC.

Foram detectadas pelos autores citados a existência de sérias dificuldades para se concretizar ações descentralizadas ao nível dos estados. Existem diferenças marcantes entre estes, como por exemplo, quanto a padrões de comportamento político, capacidade de financiamento e sustentação financeira, disponibilidade de 
informação, capacidade técnica das equipes e grau de organização da sociedade. Isto faz com que exista um descompasso significativo entre os instrumentos de gestão previsto no âmbito do PNGC e a capacidade de implementação pelos órgãos estaduais responsáveis. Acrescentam ainda que o fato das variações do grau de implementação do Programa reproduzirem os contrastes socioeconômicos regionais brasileiros, indica que o Programa não está cumprindo com a proposta de gerir a zona costeira sob uma visão unificada e consistente ao longo do país.

A predominância de cargos comissionados para posições chave no Programa acaba sendo igualmente um grande entrave à concretização de ações efetivas de gerenciamento, uma vez que as pessoas que os ocupam não são geralmente capacitadas para tal, ou seus interesses não estão de acordo com os princípios defendidos pelo Plano.

As descontinuidades administrativas são outro fator negativo, pois as constantes mudanças nos quadros técnicos e nas prioridades administrativas costumam gerar repercussões indesejáveis na implementação do Programa devido às oscilações que costumam acompanhá-las, tanto em relação ao número de pessoas envolvidas com o GERCO, como nas prioridades de ação. Desta forma, muitas atividades previamente iniciadas são usualmente interrompidas, causando perda de tempo e recursos, ou mais grave ainda, abortadas antes da sua efetivação.

Finalmente, foi destacado que existe uma falta de controle e avaliação do trabalho efetuado pelas equipes responsáveis do GERCO, o que tem originado uma falta de comprometimento com os seus objetivos e pouca concretização das metas estabelecidas pelos planos propostos.

\section{- Obstáculos Financeiros}

De acordo com os autores citados, os recursos financeiros destinados à implementação do GERCO ao nível estadual e municipal não são adequados às necessidades reais para executar as metas previstas e a sua liberação é muitas vezes descontínua e irregular, o que dificulta ações consistentes e impossibilita uma remuneração adequada dos técnicos envolvidos. 


\section{- Obstáculos socioculturais}

Por último, ficou bem claro nos trabalhos consultados que a participação da sociedade no gerenciamento costeiro foi considerada frágil e embrionária. A formação e manutenção de fóruns adequados de discussão ainda não é uma realidade no país, o que espelha a falta de capacidade de organização da sociedade, fazendo com que a sua participação não seja adequada para representar e defender os seus interesses.

Existe também uma falta de informação generalizada desta sobre os problemas que assolam as zonas costeiras e suas origens, o que dificulta ainda mais que a população se sinta como um ator com responsabilidades no gerenciamento costeiro. Obviamente que o Estado tem um papel importante na disseminação dessa informação. Contudo, deveria também haver um número bem maior de ações de educação ambiental por parte de ONGs ou instituições de ensino e pesquisa cujo trabalho se encaixa nessa linha.

\subsubsection{Potencialidades do GERCO e Caminhos Futuros.}

Obviamente não existem apenas fragilidades no Programa: uma das maiores conquistas do gerenciamento costeiro no Brasil é o grau de estruturação e sustentabilidade institucional e governamental que este atingiu. Além do mais, desde que foi criado um Plano Nacional para o Gerenciamento Costeiro, este sofreu inúmeras avaliações, reformulações e atualizações dos seus princípios, objetivos e métodos, tendo como base as experiências que foram acumuladas ao longo do tempo. Isto dá ao Programa um caráter dinâmico, contínuo e adaptativo, que vem amadurecendo ao longo do tempo, como preconizado pela $\mathrm{GCl}$.

O fato do GERCO já ter sido iniciado em todos os estados, independentemente das variações do grau de implementação, é também um fator muito importante e positivo. Tal fato só foi possível devido a uma persistência do seu desenho institucional, o que permitiu consolidar a União como órgão responsável pela coordenação nacional e instalar equipes estaduais de gerenciamento costeiro nos órgãos de meio ambiente. Como tal, as responsabilidades quanto às diferentes 
atribuições de cada nível governamental estão bem definidas, o que é fundamental para o sucesso de um programa de $\mathrm{GCl}$.

Apesar da integração inter-institucional ainda ser incipiente, a existência de fóruns específicos para tratar de questões de gestão costeira como o GI-GERCO e Câmara Técnica de Gerenciamento Costeiro no CONAMA são fatos muito positivos. Embora estes fóruns ocorram em nível federal, são exemplo para as demais esferas administrativas, demonstrando que este tipo de integração é viável e fundamental para elaborar políticas consensuais.

O desenvolvimento de novos projetos relacionados com o gerenciamento costeiro é, também, fato a se destacar. Um bom exemplo dessas iniciativas é o projeto Orla, que está possibilitando a capacitação ao nível do município e desta forma, auxiliando a reduzir a falta de atuação e comprometimento desta esfera com o Programa.

Como conclusão e fazendo uso da caracterização da $\mathrm{GCl}$ anteriormente apresentada como uma evolução de ciclos gerenciais, a evolução do GERCO pode ser representada pela Figura 4:

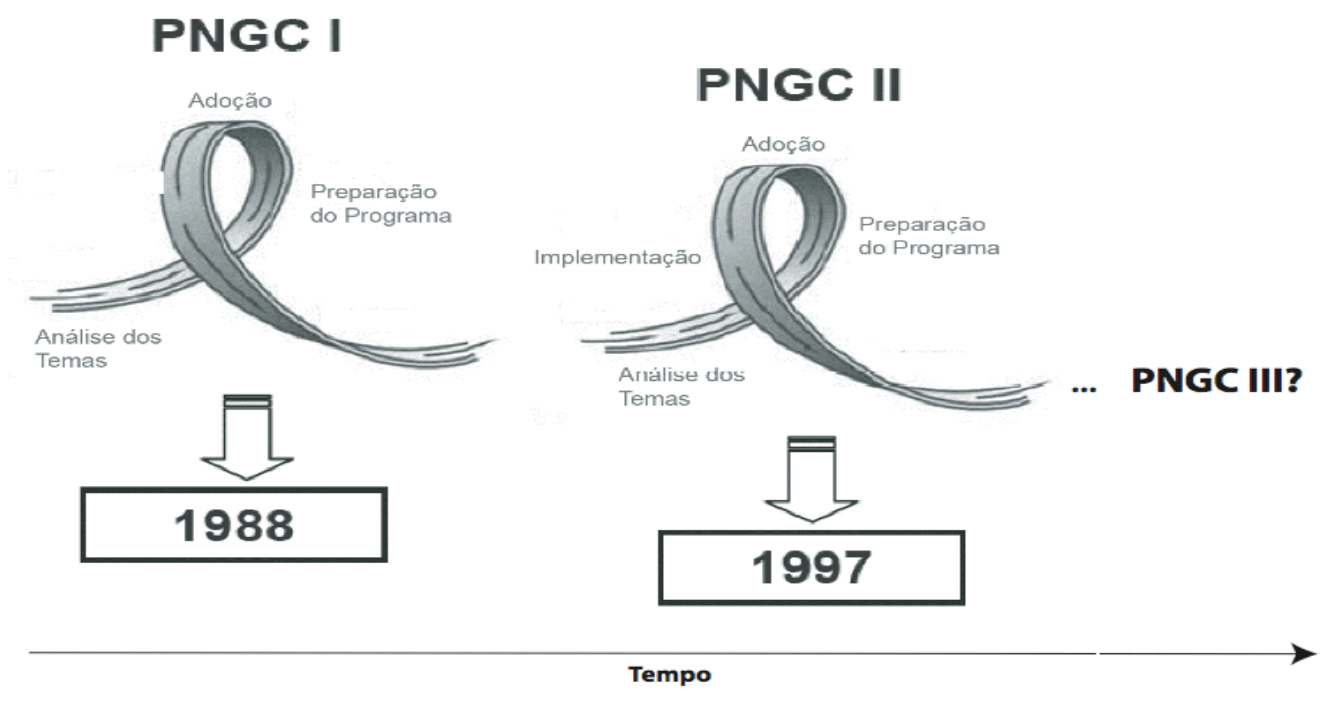

Figura 4 - Evolução do PNGC de acordo com o ciclo de GCI

(Baseado em Asmus \& Kitzmann, 2004)

Segundo Asmus \& Kitzmann (2004), no primeiro ciclo, cuja data central é 1988, pois corresponde à data em que se instituiu o PNGC I, foram identificados e 
definidos os principais temas de interesse para a zona costeira brasileira e preparados os planos e programas que foram adotados formalmente. No entanto, estes não chegaram a ser implementados ou avaliados de forma substantiva. Os principais resultados desta fase foram a instituição da base legal do GERCO, o início do zoneamento e o estabelecimento do sistema de informações SIGERCO.

De acordo com os mesmo autores, as dificuldades e problemas associados ao PNGC I assim como novas demandas conduziram o gerenciamento costeiro no Brasil para um segundo ciclo de $\mathrm{GCl}$, cuja data central é a instituição do PNGC II, em 1997. Este novo ciclo trouxe diretrizes diferenciadas ao GERCO, definiu mais claramente os seus objetivos e adotou um novo roteiro metodológico. Deste modo, foi possível implementar o GERCO em alguns estados, cujos resultados mais visíveis são o desenvolvimento do zoneamento, para pelo menos um setor costeiro, e os planos de gestão.

No entanto, o PNGC II, apesar de apresentar avanços consideráveis em relação ao primeiro ciclo, que levaram a que a etapa de implementação fosse parcialmente conseguida, também não conseguiu atingir a última etapa de avaliação. Ora, é precisamente a avaliação que permite que o seguinte ciclo de $\mathrm{GCl}$ incorpore todas as lições quanto aos sucessos e falhas que o ciclo anterior obteve e assim evolua de uma maneira cada vez mais eficiente para atingir o seu objetivo principal, o desenvolvimento sustentável da zona costeira. Assim, fica a sugestão, na Figura 4, que um novo ciclo deverá ser iniciado dando origem ao PNGC III, na expectativa que este possa finalmente concretizar todas as sua etapas, em particular a avaliação.

Deste modo, existe uma aparente concordância entre os autores de que o PNGC, apesar da sua importância estratégica para o futuro do País e dos avanços obtidos, concretizou muito pouco ao longo destes 20 anos de existência. A falta de articulação de políticas públicas incidentes nas zonas costeiras, de vontade política, assim como de metas mensuráveis e indicadores, tem levado a que o gerenciamento costeiro no Brasil pouco tenha feito para atenuar os problemas da zona costeira e melhorar a qualidade de vida da sua comunidade.

Por outro lado, o Governo ainda não abraçou a importância da revisão crítica por parte de pessoas e instituições cujas pesquisas estão relacionadas direta ou indiretamente com o gerenciamento costeiro. Sendo a $\mathrm{GCl}$, uma atividade baseada em ciência e tecnologia, esta interação é essencial para assegurar que o 
gerenciamento costeiro seja fundamentado por um arcabouço metodológico e conceitual adequado.

Todavia, apesar de todos os problemas apresentados, as ONGs, como sociedade civil organizada, e a comunidade científica, estão aparentemente cada vez mais cientes de que parte do insucesso do GERCO no Brasil é devido à pouca participação que estes têm tido no processo. Assim, muito embora as relações destes com o sistema ainda sejam superficiais e fragmentadas, o estabelecimento de ações pioneiras, como a criação da Agência Brasileira de Gerenciamento Costeiro - Agência Costeira, ou o Observatório do Litoral de Santa Catarina, indicam que o estabelecimento de redes cooperativas costeiras como uma nova estrutura de apoio poderá vir a ser um marco decisivo para o futuro do GERCO.

A Agência Costeira é uma Organização da Sociedade Civil de Interesse Público - OSCIP formada por um grupo de pessoas e instituições interessadas na resolução dos problemas de gestão do litoral brasileiro. Foi constituída para promover a convergência de ações para o gerenciamento integrado da Zona Costeira no Brasil, sendo a sua principal missão atuar como fórum de discussão independente da gestão ambiental costeira e dos problemas de desenvolvimento sustentável do Litoral Brasileiro.

Já o Observatório do Litoral é um projeto piloto formado por um conjunto de universidades de Santa Catarina cujo objetivo central é organizar e coordenar uma rede de apoio técnico-científico ao Ministério Público Federal e Estadual, tendo em vista a promoção de um estilo de gestão democrático-participativa de conflitos relacionados à apropriação dos recursos ambientais existentes na zona costeira e o conseqüente fortalecimento da cidadania ambiental no país.

Finalmente, é de salientar que, atualmente, já estão ocorrendo discussões, ainda que informais, no sentido de subsidiar a implantação de um novo Plano, o PNGC III. Estas discussões foram centralizadas durante $3^{\circ}$ Encontro Nacional de Gerenciamento Costeiro - ENCOGERCO, em 2006 e poderão, portanto, indicar que um novo ciclo de $\mathrm{GCl}$ poderá ser iniciado em breve. 


\section{Acompanhamento do Projeto Ecomanage e sua Relevância para uma Análise do Processo da GCI no Brasil}

\subsection{Estudo de Caso: o Projeto Ecomanage}

\subsubsection{Descrição e Objetivos do Projeto}

O Ecomanage (Integrated Ecological Coastal Zone Management System) é um projeto focado na $\mathrm{GCl}$ que está sendo desenvolvido em zonas costeiras de três países (Estuário de Bahia Blanca, Argentina; Estuário de Santos, Brasil; Fjord Aisén, Chile), com o intuito de criar modelos e ferramentas gerenciais eficazes e práticas para auxiliar na resolução de problemas ambientais costeiros. O seu objetivo principal é desenvolver um sistema de gerenciamento integrado para zonas costeiras com base na experiência de aplicação nesses três distintos ecossistemas costeiros da América do Sul.

O projeto foi elaborado por um consórcio internacional de instituições da Argentina, Brasil, Chile, Holanda, Itália e Portugal, tendo sido aprovado pelo $6^{\circ}$ Programa INCO de Cooperação da União Européia. Atualmente, encontra-se na sua fase final após três anos de desenvolvimento e implementação, tendo começado no final de 2004.

Os locais selecionados representam ecossistemas muito distintos, em termos climáticos, geomorfológicos, oceanográficos, desenvolvimento socioeconômico, etc, mas têm em comum a existência de importantes conflitos de interesse relativamente ao uso e ocupação da zona costeira, o que originou graves questões sociais. Estas se encontram, por sua vez, intimamente ligadas aos problemas ambientais acumulados, sendo estes geralmente conseqüência de uma regulamentação deficitária ou inadequada face ao ritmo a que as mudanças aconteceram e continuam a acontecer nestes locais.

O Ecomanage pretende produzir ferramentas desenvolvidas através de uma abordagem integrada das características físico-ecológicas e socioeconômicas dos diferentes sistemas, para serem utilizadas pelas entidades ambientais das áreas pesquisadas (ou outras partes interessadas). Essas ferramentas pretendem permitir 
a construção de diferentes cenários em função de diferentes alternativas de manejo, permitindo uma melhor escolha por parte dos tomadores de decisão.

A finalidade do projeto é, portanto, de apoiar o gerenciamento ambiental destas zonas costeiras. Tal propósito só poderá ser atingindo de forma completa uma vez que as ferramentas estiverem completamente desenvolvidas e testadas, algo que demanda tempo para ser concretizado, dependendo, entre outros, da complexidade e natureza dos conflitos e da informação existente do local.

Deste modo, sabendo que o potencial das ferramentas só será totalmente desenvolvido e aproveitado após o término do projeto Ecomanage, o grupo procurou dar uma grande ênfase para a capacitação das equipes locais para o seu uso, de maneira a que essas equipes se tornassem aptas a dar continuidade a seu uso e assim poderem assistir aos governos locais no gerenciamento costeiro. A transferência de conhecimento foi, portanto, um eixo norteador durante todo o Ecomanage, de maneira a evitar que o projeto se encerrasse em si mesmo, deixando de ter continuidade uma vez que o financiamento acabasse.

\subsubsection{Modelo Conceitual do Ecomanage}

O projeto Ecomanage é baseado nas premissas da $\mathrm{GCl}$ e, portanto, a sua filosofia é apoiada por uma visão ecossistêmica dos sistemas costeiros aos quais se dirige. Como tal, o projeto está assentado nos três seguintes princípios: (1) a zona costeira é afetada por pressões originadas localmente, mas, também, na bacia de drenagem adjacente, uma vez que suas águas são transportadas através dos rios e das águas subterrâneas para esta zona; (2) as atividades socioeconômicas são a origem dessas pressões e o seu impacto no ecossistema tem, por sua vez, repercussões socioeconômicas; e (3) os impactos dependem das características físicas do ecossistema que, juntamente com as descargas de origem antrópica, determinam o seu estado ecológico.

O modelo conceitual escolhido para se concretizar esta abordagem integrativa é o modelo DPSIR (Drivers - Pressures - State - Impact - Response) (EEA, 1999), uma vez que este modelo estrutura a descrição de problemas ambientais ao formalizar as relações existentes entre os vários setores de atividades do Homem e o Ambiente através de ligações causais, descrevendo o processo de 
gestão ambiental como um laço de feedbacks entre cinco características, a saber: Forças Motrizes, Pressões, Estado, Impactos e Respostas (Figura 5) (Bowen \& Riley, 2003).

As Forças Motrizes, ou forçantes, (Drivers) correspondem às necessidades sociais, sendo geralmente representadas por um setor econômico relevante para o problema em questão (ex: transportes, turismo, agricultura, indústria etc.). As forçantes podem ainda ser subdivididas em diretas e indiretas, dependendo da escala a que se opera. As atividades humanas originadas para suprir essas necessidades vão acabar por exercer pressões (Pressures) sobre o ambiente a um dado momento, como resultado dos processos de produção e consumo. Embora essas pressões possam ser muito variadas, elas podem ser geralmente agrupadas em 3 tipos principais: uso excessivo dos recursos naturais, modificações no uso do solo ou emissões de poluentes para a atmosfera, cursos de água ou solos (Kristensen, 2004).

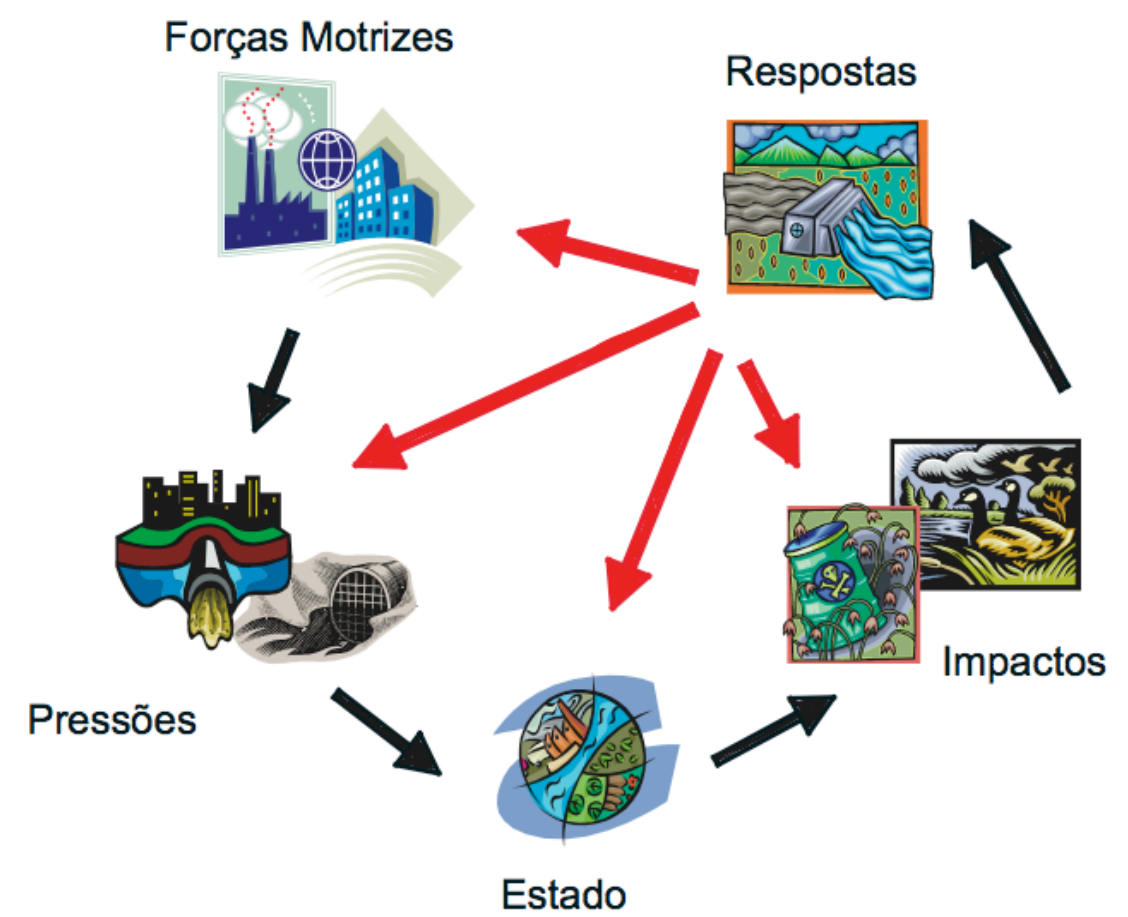

Figura 5 - O Modelo DPSIR (baseado em EEA, 1999).

As pressões vão então afetar o estado (State) do ambiente que é caracterizado pela combinação dos componentes físicos, biológicos e químicos da área em questão. O estado do ambiente é medido pela qualidade dos seus 
componentes ambientais (ar, solo, água) e pela capacidade de cumprir suas funções (serviços ecossistêmicos). Os impactos (Impacts) vão surgir como conseqüência dos efeitos das alterações no ambiente. Estes podem ser de natureza ambiental (ex: alterações no fluxo de nutrientes ou desequilíbrio nas cadeias tróficas) ou social (ex: efeitos negativos na saúde humana).

Por último, as respostas (Response) vão corresponder às ações que a sociedade vai tomar, de maneira a lidar com os problemas ambientais que foram identificados como conseqüência de suas atividades. Estas respostas geralmente surgem sob forma de políticas que podem estar direcionadas para qualquer componente do ciclo causal.

O modelo conceitual DPSIR permite, assim, traduzir os problemas ambientais e as soluções gerenciais em variáveis que evidenciam as relações causa-efeito existentes entre as atividades humanas, o estado das zonas costeiras e a resposta da sociedade a essa condição (Lin et al, 2007).

\subsubsection{Os Instrumentos do Ecomanage}

Procurou-se estabelecer para cada um dos locais estudados uma base de dados que sintetizasse a informação relevante existente sobre cada local, um modelo integrado para descrever os processos do ecossistema, e um sistema de apoio à decisão (Decision Support System - DSS) que integrasse todas as informações e ajudasse a ponderar a elaboração de respostas pelos decisores, além de um conjunto de indicadores que servirão tanto para monitorar a evolução dos diferentes parâmetros acima descritos como também o efeito das ações recomendadas e, assim, retro-alimentar todo o processo.

A base de dados permite que toda a informação existente ou coletada pelo projeto possa ficar centralizada e facilmente acessível. Esta base de dados poderá ser consultada através de um portal web que terá acesso livre, ajudando assim na divulgação e disseminação da informação, prática ainda incipiente nos países em questão.

O modelo integrado é um modelo interdisciplinar, resultado do acoplamento de modelos matemáticos físicos e ecológicos, contemplando águas superficiais e subterrâneas da bacia de drenagem, que possibilitará entender os processos 
hidrodinâmicos atuantes nos ecossistemas costeiros selecionados e também os efeitos das pressões antropogênicas, em toda a sua bacia de drenagem. Como o modelo pretende permitir fazer previsões do comportamento dos sistemas costeiros sob diferentes cenários, ele será também utilizado num último momento para ajudar a avaliar o efeito das propostas dos stakeholders considerando possíveis cenários de desenvolvimento.

O Sistema de Apoio à Decisão (Decision Support System) - DSS, é a ferramenta que permitirá construir cenários de desenvolvimento e avaliar o impacto desses cenários nas condições ambientais e socioeconômicas dos locais. O DSS utilizado foi basicamente um software de análise multi-criterial (Sprague \& Watson, 1986; Munda, 1995) aplicado sobre matrizes de decisão. Essas matrizes correspondem a tabelas de alternativas/efeitos para os quais serão atribuídos valores qualitativos e que, após processamento, servirão para identificar qual a melhor alternativa gerencial para o problema em causa. Este trabalho deve ser feito conjuntamente com stakeholders locais, de maneira a que os cenários trabalhados sejam realistas e correspondam a uma visão partilhada sobre o futuro desejado do sistema.

Finalmente, serão escolhidos indicadores relativos a parâmetros chave dos sistemas que permitirão quantificar as pressões e o estado atual e futuro do sistema frente a essas pressões. Desta maneira, eles servirão para monitorar a evolução desses parâmetros ao longo do tempo e verificar se as ações propostas ou acordadas para a região vão ter um efeito significativo na melhoria da qualidade ambiental e de vida das populações locais.

Como mencionado anteriormente, o presente trabalho deverá ater-se à apresentação dos aspectos chave do desenvolvimento do projeto Ecomanage apenas na região do complexo estuarino de Santos - São Vicente, região na qual foram acompanhados os trabalhos. Segue-se então a descrição dos principais aspectos do desenvolvimento do projeto Ecomanage na Baixada Santista.

\subsection{Desenvolvimento do Projeto Ecomanage na Baixada Santista}

A área abrangida pelo projeto corresponde aos cinco municípios nos quais que se insere o sistema estuarino de Santos - São Vicente e que compõem a 
Baixada Santista: Praia Grande, São Vicente, Santos, Cubatão e Guarujá. Quanto à equipe local do Projeto Ecomanage, ela é composta por investigadores de duas instituições: Instituto Oceanográfico da Universidade de São Paulo (IO-USP), São Paulo, e Universidade Santa Cecília (Unisanta), em Santos.

\subsubsection{Descrição dos Principais Conflitos Socioambientais da Baixada Santista}

Os principais problemas socioambientais da Baixada Santista são resultantes de atividades muito diversas e mesmo conflitantes: a região abriga uma grande zona industrial implantada na área interna do estuário, o maior porto da América Latina, e representa a principal área turística de veraneio do estado, principalmente pela proximidade da sua capital.

A origem desses conflitos está intimamente ligada ao processo de urbanização e desenvolvimento da região. O Porto de Santos, atualmente o maior da América Latina tanto em movimentações como em infra-estrutura, foi o principal dinamizador da região. A expansão da atividade agrícola ocorrida a partir de meados do séc. XIX, em particular da indústria cafeeira no interior do estado de São Paulo, obrigou a um grande aumento da movimentação de cargas no Porto de Santos, resultando inclusive na construção da primeira ligação ferroviária entre o litoral e o planalto paulista, a São Paulo Railway, inaugurada em 1867 (CODESP, 199-).

Esta ligação melhorou substancialmente o sistema de transportes da época e serviu de estímulo ao comércio e ao desenvolvimento da cidade e do Estado de $\mathrm{S}$. Paulo. Verificou-se, então, que o aumento da produção cafeeira, levou à necessidade de ampliação e modernização das instalações portuárias. Desde então, o porto não parou de se expandir, atravessando todos os ciclos de crescimento econômico do país, aparecimento e desaparecimento de tipos de carga, até chegar ao período atual de amplo uso dos contêineres e movimentando cargas diversas (como açúcar, café, laranja, algodão, adubo, carvão, trigo, sucos cítricos, soja, veículos e granéis líquidos diversos) (CODESP, 199-).

A proximidade da região metropolitana de São Paulo como centro consumidor, a construção de uma desenvolvida infra-estrutura de transporte rodoviário, ferroviário e portuário e a facilidade de obtenção de água e energia 
elétrica devido à proximidade e abundância de rios na região, levaram, a partir da década de 1950, à implantação de diversas indústrias de base (siderurgia, petroquímica, fertilizantes), dando origem ao Parque Industrial de Cubatão (Lamparelli et al., 2001).

Porém, a instalação deste complexo industrial ao sopé da Serra do Mar atendeu apenas a interesses econômicos, sendo que as indústrias foram se localizando de acordo com vantagens imobiliárias ou pré-requisitos necessários às suas operações (como proximidade de núcleos urbanos e de cursos de água). Ora, as condições geomorfológicas desta zona (e padrões de circulação de ar associados) não permitem uma adequada dispersão da poluição atmosférica (Afonso, 2006). Por outro lado, essas indústrias também utilizaram o sistema estuarino como um grande receptor de resíduos tóxicos e efluentes líquidos contaminados (Lamparelli et al., 2001).

A falta de uma legislação adequada e uma fiscalização eficiente à época, levou a que Cubatão se tornasse, no final dos anos 1970, início dos anos 1980, um dos lugares mais poluídos do mundo, tendo sido apelidado pelo The New York Times de 19/9/1980 como "o vale da morte", devido aos impactos que as emissões atmosféricas e líquidas das indústrias estavam tendo na saúde das populações estabelecidas na região, tendo sido relatados, inclusive alta incidência de casos de natimortos ou com graves deformações congênitas.

Perante este quadro gravíssimo e já com repercussões internacionais, procedeu-se, a partir de 1984, a um intensivo programa de controle da poluição do ar, das águas e do solo de maneira a reverter o processo de degradação ao qual os ecossistemas costeiros da região estavam sendo sujeitos e também os efeitos deletérios da poluição (Lamparelli et al., 2001), tendo-se obtido desde então uma redução de mais de $90 \%$ das fontes emissoras de poluição, de acordo com dados da prefeitura de Cubatão.

No entanto, apesar de Cubatão ser um exemplo de recuperação ambiental, a região permanece impactada por elevadas concentrações de metais pesados e compostos organoclorados na água, nos sedimentos e nos organismos aquáticos (peixes e crustáceos). De acordo com Lamparelli et al (2001) esta situação é particularmente grave para a população local, devido ao grande número de pessoas que consomem esses pescados, além de representar uma importante atividade econômica para a população de menor poder aquisitivo. 
Os mesmos autores consideram mesmo que o pólo industrial de Cubatão ainda representa atualmente a fonte principal de poluentes químicos para o sistema estuarino de Santos - São Vicente e ambiente marinho adjacente, pela diversidade e quantidade de substâncias emitidas atualmente e pela contaminação originada pelo passivo ambiental.

Não obstante os problemas ambientais que surgiram das atividades industriais e portuárias desenvolvidas, estas foram também as responsáveis pela acentuada melhoria da qualidade de vida de uma parcela significativa da população. No entanto, esse desenvolvimento socioeconômico tem igualmente sido acompanhado por uma expansão urbana desordenada, fruto das acentuadas desigualdades sociais que se estabeleceram nas últimas décadas (Sampaio et al., 2007).

Os municípios de Santos e São Vicente, sede da Baixada Santista e os mais densamente povoados da região (Figura 6), defrontaram-se, no final dos anos 1960, com uma urbanização em saturação, o que levou a uma mudança do comportamento demográfico, econômico e social da região nos anos 1970 e 1980 . Este período foi caracterizado por um grande crescimento populacional que acabou por resultar num processo de aglomeração urbano desordenado e caótico, produzindo espaços que submeteram a população a situações de risco ambiental (Young \& Fusco, 2006).

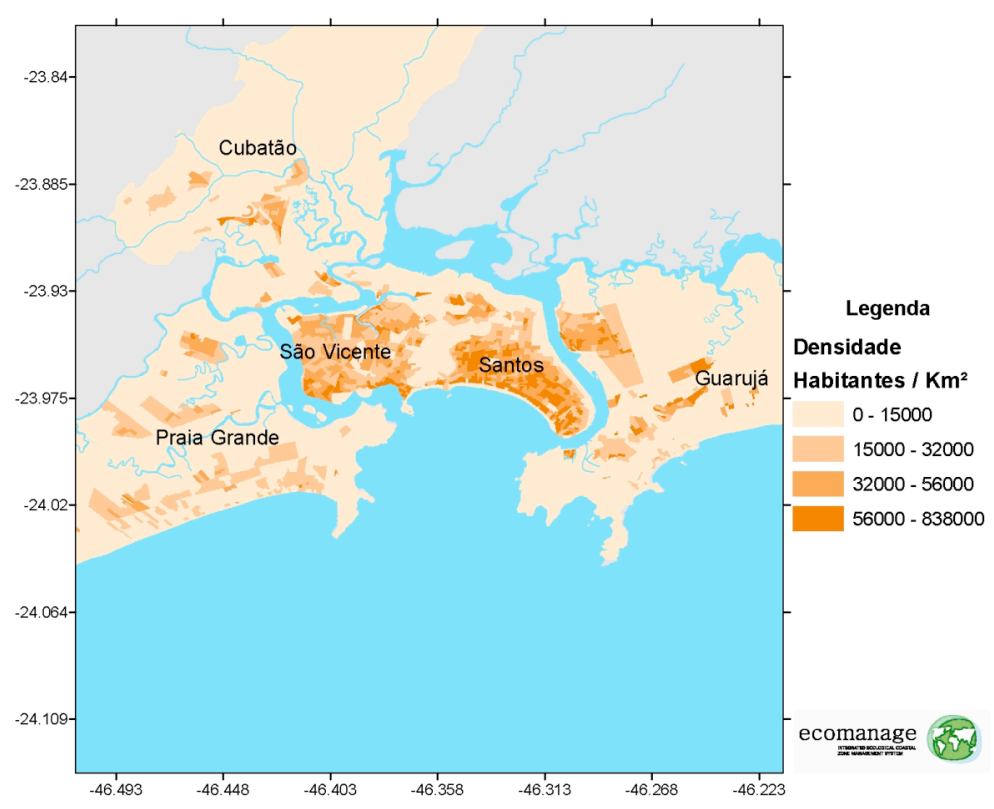

Figura 6 - Densidade populacional nas áreas pertencentes a bacia do estuário de Santos - São Vicente a partir dos dados do IBGE, 2000 (Fonte: Sampaio et al., 2007) 
Foi assim que a partir dessa altura se deu início ao processo de favelização nos municípios do sistema estuarino de Santos - São Vicente. Este fenômeno foi fortemente impulsionado, de acordo com Jakob (2003), pela migração de pessoas vindas do sudeste e nordeste do país e principalmente da Região Metropolitana de São Paulo, que vinham à procura de oportunidades de trabalho, propiciadas pelo crescimento das atividades econômicas que se desenvolviam na região. $O$ adensamento populacional causado por essa migração, obrigou a uma descentralização espacial da população, gerando um crescimento desordenado nas zonas periféricas correspondentes aos municípios de Guarujá, Cubatão e Praia Grande e até mesmo com ocupações irregulares em regiões protegidas.

De acordo com dados do IBGE (2000) e AGEM (2005), existe um grande número de habitações subnormais e/ou favelas (Figura 7), acentuado nas zonas periféricas da região, dentre as quais, uma parcela significativa de pessoas vive sobre palafitas, localizadas principalmente nas margens dos rios e sobre áreas de manguezal (Figura 8) .

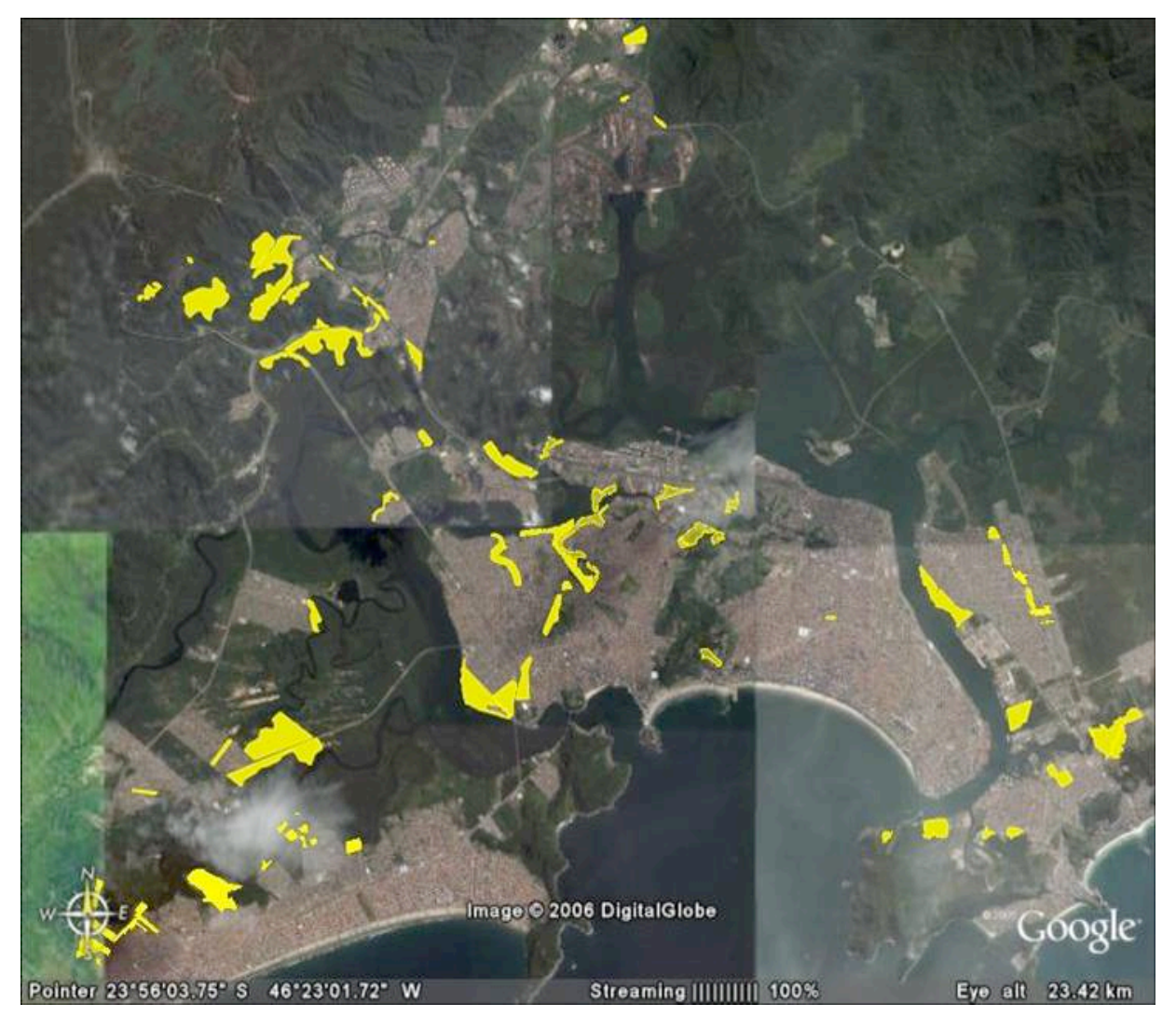

Figura 7 - Distribuição espacial de sub-moradias, em amarelo, na Baixada Santista (Fonte: Sampaio et al., 2007) 


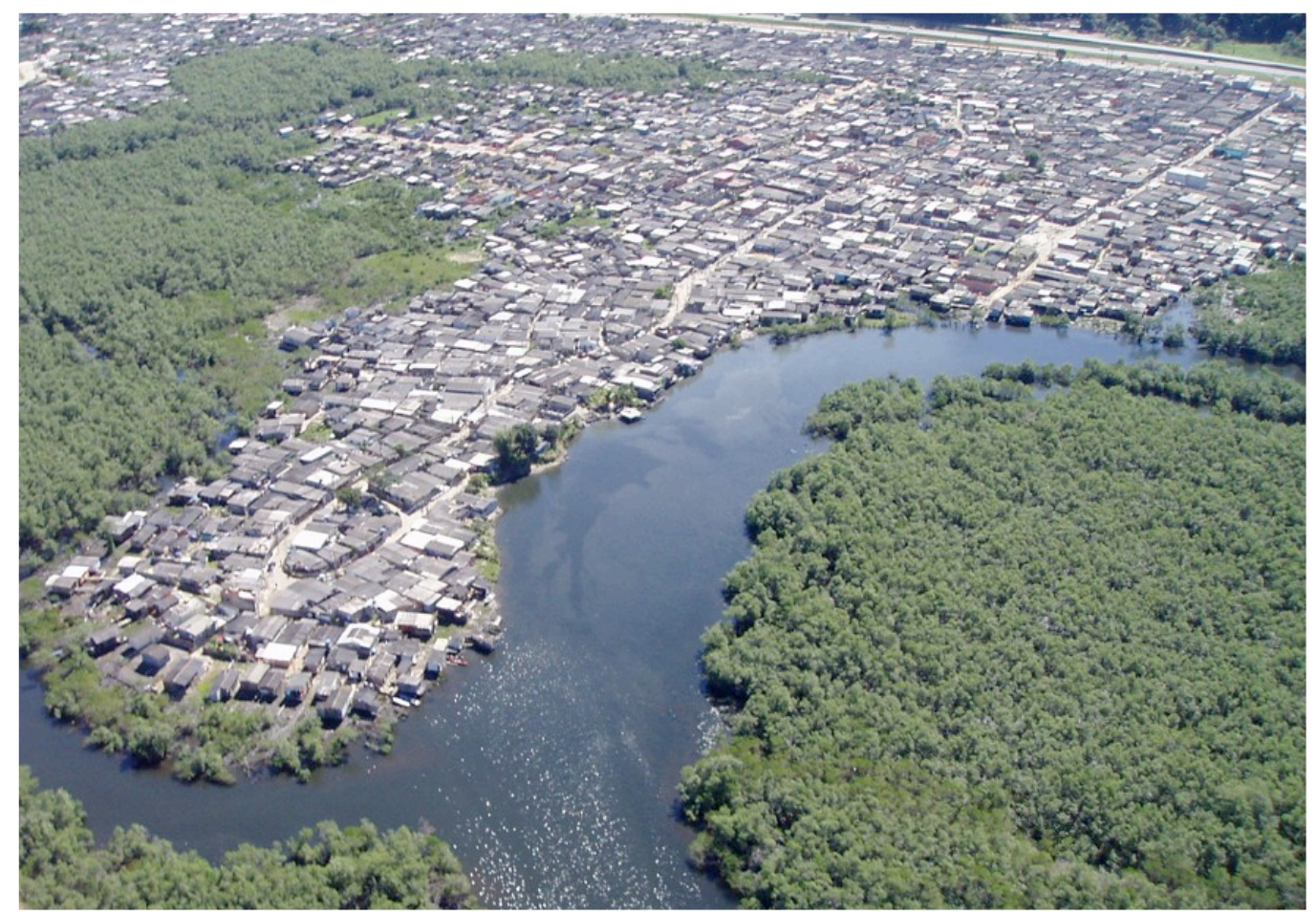

Figura 8 - Avanço das sub-moradias em áreas de manguezais (Autor: Hélio Lopes)

Esse quadro é ainda agravado pelo fato de grande parte do total dessas habitações não possuírem rede de coleta e tratamento de esgoto adequado. Assim, uma vez que a maioria se encontra situada nas margens de rios e manguezais, volumes consideráveis de efluentes domésticos acabam sendo drenados diretamente no estuário, causando grave impacto na saúde pública (CETEC/CETAM, 2000) e mesmo no turismo da região.

Apesar de já estar em andamento um projeto de expansão da rede coletora e tratamento de esgoto nas áreas urbanas dos nove municípios da Baixada Santista, denominado Projeto "Onda Limpa", este não é dirigido à população que ocupa irregularmente áreas situadas às margens de rios e canais do estuário, estando apenas direcionado à população que vive em áreas urbanizadas porém que ainda não contam com rede coletora de esgoto (SAMPAIO et al, 2007). Aquela parcela de população irá, portanto, continuar a representar uma fonte significativa de contaminação do estuário. Deve-se ressaltar que tem havido esforços do governo estadual e municipal e mais recentemente do governo federal através do PAC, Plano de Aceleração do Crescimento, para regularizar parte destes assentamentos ilegais. Porém, os altos custos imobiliários associados a estes empreendimentos na região, devido às características desfavoráveis do solo e escassez de áreas disponíveis, 
encarecem sobremaneira esta ação e acabam por contemplar um contingente sempre muito aquém do que é necessário ( Sampaio et al., 2007)

Como conclusão, o relatório efetuado pela CETESB em 2001, correspondendo ao último levantamento sistemático sobre a contaminação ambiental da região, apontou como principais causas de degradação do sistema estuarino de Santos - São Vicente a poluição de origem doméstica e industrial (responsável pela contaminação química e biológica) e as alterações físicas dos habitats, resultantes de processos de erosão, assoreamento, aterros de canais e manguezais e intervenções no sistema de drenagem, tendo este quadro originado grande impacto na área social e saúde pública.

O Projeto Ecomanage - Baixada Santista, foi desenvolvido nessa conjuntura de conflitos socioeconômicos e no contexto do quadro legal atual de gestão costeira do Brasil. Situa-se fora do escopo do presente trabalho a apresentação dos resultados do projeto em si, uma vez que, desde já, inúmeras informações já se encontram disponíveis no site do projeto e, assim que o mesmo esteja concluído, todos os produtos e resultados estarão ali disponibilizados e também sob o formato de livro, pelo endereço www.ecomanage.info. Desta forma, serão descritos em seguida, os procedimentos relativos ao desenvolvimento do projeto na Baixada Santista, para depois, então, apresentar uma análise das dificuldades e oportunidades que surgiram durante a implementação deste projeto que pretendeu ser um modelo de estudo integrado, baseada no conhecimento dos conflitos existentes na região e do processo de gestão costeira no Brasil, apresentado anteriormente.

\subsubsection{Procedimentos da Implantação do Projeto Ecomanage na Baixada Santista}

Geralmente, todo o processo de $\mathrm{GCl}$ surge como resposta para resolver determinados problemas de desenvolvimento. O Projeto Ecomanage surgiu com o intuito de providenciar ferramentas para auxiliar a delinear respostas para os inúmeros conflitos socioambientais existentes na Baixada Santista, tendo sido 
escolhidos, neste primeiro momento, problemas relativos ao grau de urbanização, tais como a questão da contaminação da água do estuário e baía de Santos por origem doméstica e a questão do altíssimo número de pessoas em sub-moradias que estão vivendo em condições precárias.

\subsubsection{Os principais Passos do Desenvolvimento do Projeto}

- Elaboração do diagnóstico socioambiental e caracterização dos principais conflitos costeiros

O primeiro passo consistiu em tentar identificar e caracterizar os principais conflitos costeiros sob o ponto de vista físico, ecológico e socioeconômico. Para tal, elaborou-se um diagnóstico da área realizado com base no levantamento de dados pré-existentes, tanto sobre as condições socioeconômicas como em relação aos principais problemas ambientais existentes. Uma primeira etapa desse diagnóstico foi realizada através de consultas a especialistas e também através da própria experiência de trabalho na área dos integrantes da equipe do projeto. Foram também levantados novos dados de campo para suprir algumas informações consideradas essenciais, através de campanhas de amostragem no sistema estuarino, visando avaliar vários parâmetros físicos, químicos e biológicos do ecossistema, de maneira a alimentar o modelo integrador e caracterizar o estado do ambiente.

Esta modelação dos principais processos ocorrentes neste sistema costeiro teve uma importância fundamental para a elaboração do diagnóstico, pois foi a partir desta abordagem integrada que foi possível entender as forças socioeconômicas, biogeoquímicas e físicas ali existentes, responsáveis pela distribuição espacial das atividades econômicas e dos assentamentos humanos (e qualidade ambiental associada).

- Seleção do problema a ser analisado

Uma vez concretizado o diagnóstico, verificou-se que a complexidade associada aos conflitos existentes era demasiadamente elevada para que se 
pudesse tentar trabalhar com todos, dentro do horizonte temporal do projeto e com a limitação de recursos humanos disponível. Foi, então, necessário fazer uma escolha por parte dos pesquisadores do problema para o qual seriam desenvolvidas as ferramentas previstas no projeto, dentre as principais questões levantadas. Essa escolha foi realizada apenas pelos pesquisadores do projeto, sem a participação dos stakeholders, considerando-se que seria necessário ponderar principalmente a questão temporal para a conclusão do projeto e a complexidade de certas questões.

Além disso, o Projeto Ecomanage tem por objetivo disponibilizar ferramentas práticas, que suscitem o interesse dos stakeholders para as aplicar no gerenciamento dos problemas costeiros. Ora, verificou-se que para que esse interesse surgisse, ou seja, para que se conseguisse envolver um número mínimo de pessoas e instituições de todas as esferas da sociedade no projeto (e em particular do poder público), as questões tratadas pelo Projeto Ecomanage teriam de ter a maior neutralidade possível em termos políticos.

Assim, optou-se por uma questão que fosse o menos controversa possível, a fim de se conseguir o envolvimento dos stakeholders. Os três principais problemas identificados na Baixada Santista - urbanização, atividades industriais e portuárias são altamente complexos e de difícil resolução em vários níveis (político, técnico, econômico, ambiental, etc.). Porém, após discussão entre os membros do projeto considerou-se que seria mais viável conseguir o interesse quanto a possíveis respostas para a questão da urbanização, pois ela está, acima de tudo, relacionada com a melhoria da qualidade de vida das pessoas, mesmo havendo outras questões envolvidas. Já em relação aos problemas derivados da indústria ou das atividades portuárias, as questões geraram insegurança por parte dos stakeholders a respeito de qualquer medida proposta. Estas iriam, com certeza, envolver questões demasiadamente delicadas (tal como os projetos de expansão do Porto ou a contaminação dos solos e águas pelas indústrias) para se poder obter consenso num primeiro momento. Deste modo, optou-se por descartar estas últimas questões nessa fase de desenvolvimento do projeto, para apenas lidar com o igualmente grave problema do alto grau de urbanização, mas sempre tendo em conta que estes problemas setoriais não estão dissociados.

A expectativa do grupo de pesquisadores, no entanto, é de que, com o resultado do trabalho efetuado para os problemas decorrentes da urbanização, se possa, por um lado, ganhar a confiança dos stakeholders na potencialidade das 
ferramentas e, por outro, obter uma visão partilhada quanto ao futuro desejado do estado da Baixada Santista. A partir dessa etapa concluída e com a capacitação de recursos humanos para as ferramentas, espera-se avançar para questões como as do porto ou das indústrias.

Uma vez selecionada a urbanização como o problema central (driver indireto) do Projeto Ecomanage para a Baixada Santista, foram identificados dois problemas importantes (drivers diretos) e de interesse por parte dos stakeholders associados a essa questão. Verificou-se, então, que estes podiam basicamente ser divididos em dois aspectos, os assentamentos humanos e o saneamento.

- Determinação das pressões e impactos do problema: o papel do Sistema de Apoio à Decisão

O passo seguinte consistiu, portanto em caracterizar as pressões (pressures) associadas a esses dois problemas e avaliar o efeito que estas estavam tendo no ambiente (impacts), para então poder ajudar a traçar respostas gerenciais (responses) destinadas a resolver ou minimizar estes problemas ou, pelo menos, indicar quais as melhores alternativas. A determinação destes três últimos parâmetros do modelo conceitual do Projeto Ecomanage foi, sobretudo, feita através do Sistema de Apoio à Decisão.

A construção do DSS foi a ferramenta que mais obrigou a um envolvimento ativo dos stakeholders. Anteriormente, a participação destes no projeto tinha-se resumido ao comparecimento de reuniões de caráter informativo, organizadas pela equipe. A primeira dessas reuniões foi realizada no auditório da UNISANTA, para a qual foram convidados representantes de órgãos governamentais, dos governos municipais e estaduais, representantes das indústrias e da Administração do Porto de Santos, representantes das universidades locais e de várias ONGs, assim como vários mídia. Foram considerados órgãos governamentais todas as instituições ligadas ao governo (como a CETESB ou SABESP), mas que não representassem diretamente o governo (estadual ou municipal). É feita esta distinção entre órgãos governamentais e governo porque estes dois grupos de stakeholders tiveram uma participação bem distinta ao longo do projeto, apesar de ambos representarem o poder público. 
Esta primeira reunião teve o objetivo de apresentar o projeto à sociedade, esclarecendo os objetivos e metas do Projeto Ecomanage. Outro objetivo dessa reunião foi identificar os convidados realmente com interesse no projeto. Ao final dos trabalhos, foi constituído um "Conselho Consultivo" do projeto, com a participação dos elementos mais interessados, que seriam pessoas que estariam colaborando ativamente com informações para o diagnóstico e teriam maior interesse em verificar os resultados das ferramentas a serem desenvolvidas pelo projeto. Foram igualmente efetuadas outras duas reuniões ainda de âmbito informativo com os stakeholders,_ao final do primeiro e do segundo anos de trabalho, para apresentar os resultados do diagnóstico alcançados até então e o andamento do modelo numérico, cujos modelos de base já se encontravam validados para se testar os cenários. Também foram mencionados os passos seguintes do projeto em que seria necessária maior participação dos stakeholders.

Foi, portanto, apenas no terceiro e último ano do projeto e após a caracterização quali e quantitativa dos problemas dos assentamentos humanos e do saneamento, que se pôde começar a construção do DSS, quando os stakeholders passaram a ter um envolvimento não apenas consultivo, mas verdadeiramente participativo.

Para tal, foi necessário, antes de tudo, formalizar-se um grupo de trabalho composto por atores que representassem os vários setores da sociedade e pelos membros da equipe. Uma vez este grupo montado, efetuaram-se várias reuniões técnicas com a finalidade de construir as matrizes de decisão. Discutiram-se as alternativas de gestão possíveis para os problemas em questão, os diferentes critérios ambientais e socioeconômicos a serem utilizados para ponderar o efeito dessas alternativas e o impacto desses efeitos. Os campos das matrizes foram, portanto, preenchidos com base no conhecimento específico da equipe e dos stakeholders. No final, as matrizes foram processadas e obteve-se uma classificação das alternativas, mostrando qual seria a melhor alternativa para o problema, de acordo com a análise qualitativa conjunta dos participantes. 


\subsubsection{Considerações sobre o Desenvolvimento do Sistema de Apoio à Decisão}

Cabe aqui destacar alguns pontos relativos a este processo, pois servirão para embasar a discussão que se segue.

Relativamente à composição do grupo de stakeholders, verificou-se que as pessoas que se disponibilizaram para montar este grupo, correspondiam às que tinham mostrado interesse em colaborar desde o início. Eram pessoas que estiveram presentes em todas as reuniões ou que tinham vindo a apoiar o projeto através do fornecimento de dados ou de informações fundamentais para a elaboração do diagnóstico e dos modelos.

Assim, apesar de ter havido um esforço para conseguir ter representantes de todas as esferas da sociedade, verificou-se uma falta de adesão mais ampla, sobretudo por parte de representantes da sociedade civil. O grupo foi, então, formado principalmente por representantes de órgãos governamentais estaduais e municipais, de secretarias do meio-ambiente ou urbanização dos municípios e de instituições de ensino e pesquisa. Apenas um dos municípios componentes da Baixada Santista apresentou participação e colaboração incipientes apesar dos vários convites para um aprofundamento dessa colaboração.

Quanto à participação efetiva do grupo nas reuniões e engajamento no trabalho pretendido, verificaram-se dificuldades em manter o grupo coeso, apesar do interesse demonstrado. Assim, depois da reunião técnica inicial no âmbito do DSS com mais de vinte participantes, a reunião seguinte já teve menos de metade dos participantes, o que obrigou a equipe a mudar de estratégia.

Inicialmente, pretendia-se realizar reuniões em número suficiente para montar e preencher as matrizes de decisão juntamente com os stakeholders, de maneira a que os dados inseridos resultassem do consenso obtido entre os vários integrantes, o que ocorreu com bastante sucesso na primeira reunião técnica. Esta era uma estratégia para promover o diálogo e partilhar visões entre atores sociais que não têm o hábito de se associar e de dialogar, particularmente para as questões em pauta.

No entanto, a falta de uma adesão continuada nas reuniões dificultou essa intenção. Desta forma, optou-se por mandar por correio eletrônico as matrizes construídas em conjunto após a segunda reunião, para serem preenchidas por cada 
stakeholder no seu local de trabalho. Salienta-se que, como o processo era novo para os stakeholders participantes, optou-se por começar a trabalhar com matrizes previamente preenchidas pela equipe do projeto quanto a algumas alternativas e efeitos, de maneira a exemplificar o tipo de trabalho pretendido. No final desta segunda reunião, já foi possível inserir outras alternativas e efeitos nas matrizes, após sugestão dos stakeholders. O trabalho efetuado "em casa" foi, portanto, incorporado nas matrizes e realizado principalmente no sentido de se ponderar os impactos de cada alternativa relativamente aos efeitos considerados, atribuindo-lhes valores qualitativos.

Estas matrizes foram, então, reenviadas para a equipe após um prazo prédeterminado. A partir dos resultados sugeridos pelos stakeholders foi feita uma média dos valores e obtiveram-se duas matrizes finais distintas, uma para o problema de saneamento e outra para os assentamentos humanos. Estas matrizes finais corresponderam, portanto, a uma média das visões de cada stakeholder e não a uma visão consensual, obtida através de debate, como originalmente concebido.

Ressalta-se que esta mudança de estratégia revelou-se acertada, pois quando se marcou finalmente uma reunião final para apresentação dos dados e do resultado do processamento, verificou-se que a maioria dos stakeholders não compareceu. Ora, esta reunião iria precisamente servir para demonstrar a utilidade e a potencialidade que esta ferramenta tem para auxiliar a desenhar soluções possíveis e identificar os impasses e os problemas chaves destas questões a partir de uma visão múltipla. Esta falta de resposta por parte dos atores revelou, portanto, a dificuldade em se praticar este tipo de gestão participativa na região. Isto já era até certo ponto esperado, pois, apesar de ter sido oferecido um prazo considerável para preenchimento das matrizes e tendo sido escolhido o correio eletrônico como meio de comunicação para facilitar o seu reenvio, grande parte dos stakeholders não tinha retornado as matrizes preenchidas.

\subsection{Avaliação das Dificuldades e Oportunidades da Implementação de um Projeto como o Ecomanage no Brasil}


O trabalho desenvolvido pelo Ecomanage propiciou à equipe de pesquisadores interagir com várias instituições governamentais e não governamentais regionais e locais, o que criou uma oportunidade única para identificação dos pontos positivos e negativos desta interação e o estabelecimento de um paralelo com a situação atual do gerenciamento costeiro no Brasil. Esta será portanto uma análise qualitativa, resultante de uma avaliação pessoal e conjunta com membros da equipe do projeto.

\subsubsection{Análise das Principais Dificuldades de Implementação.}

Os obstáculos encontrados ao longo do projeto são em muito semelhantes aos anteriormente descritos para o gerenciamento costeiro no País e estão relacionados com aspectos técnico-administrativos, político-institucionais, e sócioculturais. Neste caso pode-se considerar que não houve obstáculos financeiros, pois o financiamento era de origem externa e já estava assegurado desde o início.

Com relação aos aspectos técnico-administrativos, verificou-se que as dificuldades não residiram tanto na falta de informação ou capacitação inicial dos participantes. Obviamente que existiam lacunas, mas de um modo geral, e sobretudo quando comparado com outras regiões brasileiras, pode-se dizer que a informação existente relativamente a aspectos socioeconômicos, físicos e biológicos da Baixada Santista já é substancial. Isto resulta do fato de existirem várias instituições de ensino e pesquisa na própria região e no estado e também do grau de desenvolvimento e organização administrativa da região, permitindo a existência de diversos dados oficiais disponíveis.

No entanto, um problema identificado consistiu na freqüente falta de continuidade dos trabalhos de geração de bancos de dados, levando à desatualização ou irregularidade dos mesmos. Por outro lado, e, sobretudo, em relação aos dados oficiais verificou-se uma falta de uniformidade em relação aos métodos utilizados, resultando em disparidades entre os dados dos municípios constituintes da região Metropolitana de Santos, muito embora exista uma base cartográfica unificada para a região metropolitana da Baixada Santista. Além disso, o acesso é restrito ao público, que não pode explorar devidamente as 
potencialidades que este tipo de instrumento oferece. Assim, o projeto Ecomanage não pôde utilizar-se destas bases cartográficas.

Além do problema da consistência e validade dos dados disponíveis, verificou-se, igualmente, que estes estão altamente dispersos, o que dificulta a sua obtenção (até porque muitas vezes não se sabe da sua existência). Outras vezes, a sua disponibilização é dificultada devido a processos burocráticos ou mesmo porque são de natureza sigilosa. Por último, notou-se uma certa falta de capacitação técnica específica do setor público, com grandes disparidades entre os municípios.

Quanto aos aspectos político-institucionais, dois aspectos se salientaram com respeito às dificuldades, aspectos que, aliás, estão intimamente ligados: a falta de vontade política para solucionar os conflitos socioambientais da região e a existência de importantes pressões lobistas sobre os governos locais. Os interesses econômicos na Baixada Santista, sobretudo aqueles relacionados aos setores portuário, industrial e imobiliário, ainda são, infelizmente, os que determinam as agendas políticas.

Assim, apesar do esforço que vem existindo por parte do setor público para introduzir os aspectos sociais na agenda e, em menor escala, os ambientais, estes aspectos mantêm-se geralmente apenas no discurso político. O interesse por projetos da natureza do Ecomanage não são, portanto, encarados como oportunidades para os tomadores de decisão, não suscitando um verdadeiro engajamento.

É de ressaltar, no entanto, que este cenário não é totalmente homogêneo em todos os municípios, havendo inclusive municípios que já estão dando importantes passos nesse sentido (como por exemplo, com projetos de requalificação ambiental ou de realojamento de população de sub-moradias). Contudo, estas iniciativas são específicas e pontuais e não fazem parte de um plano maior para a região metropolitana como um todo, a exemplo do que ocorre, p.ex. com o projeto de saneamento ambiental ${ }^{12}$. Assim, estas iniciativas permanecem insuficientes perante a natureza e profundidade dos problemas socioambientais, apesar da sua importância e de poderem apontar um futuro mais promissor, evidenciando que os

12 Programa de Recuperação Ambiental da Região Metropolitana da Baixada Santista financiado pelo Japan Bank for Internacional Cooperation (JBIC), com contrapartidas da Companhia de Saneamento Básico do Estado de São Paulo (Sabesp) e do Banco Nacional de Desenvolvimento Econômico e Social (BNDES). 
tomadores de decisão priorizam o desenvolvimento econômico na região, deixando as questões socioambientais em segundo plano.

Outro obstáculo político-institucional, foi a falta de integração interinstitucional ressentida, que está comprometendo um diálogo efetivo entre os vários atores que participam na gestão costeira. Notou-se que, apesar de já existirem mecanismos formais administrativos que poderiam promover essa integração (como um conselho - CONDESB $^{13}$ - e uma agência - AGEM ${ }^{14}$ - intermunicipais, o Grupo Setorial do Gerenciamento Costeiro ou o Comitê da Bacia Hidrográfica da Baixada Santista), os trabalhos encontram-se pouco avançados no sentido de promover ações concretas com órgãos tanto governamentais como não governamentais e por fim, com a sociedade em geral. Estes fatos, indubitavelmente, decorrem diretamente da falta de vontade política, apontada acima.

Assim, as secretarias municipais ligadas ao meio-ambiente e seus conselhos $\left(\right.$ COMDEMA $\left.^{15}\right)$ revelam-se igualmente pouco ativas. Além do mais, visto que os COMDEMAs não estão integrados intermunicipalmente, as ações destas secretarias relativas às questões comuns entre eles nestes fóruns são menos eficientes. Adicionalmente, constatou-se que ainda não existem políticas públicas ambientais municipais claramente definidas (sendo que, mais uma vez, existem municípios com maior inércia que outros), o que dificulta igualmente a tomada de ações concretas por parte dos órgãos responsáveis.

Não é, portanto, de admirar que exista uma falta de comunicação e, sobretudo, de retorno entre esses atores, cujas ações permanecem fortemente setorizadas. Assim, os problemas que são comuns à região acabam tendo a sua resolução confinada a limites político-administrativos, como resultado da falta de

13 O CONDESB - Conselho de Desenvolvimento da Região Metropolitana da Baixada Santista - é um conselho formado por representantes das prefeituras da RMBS e representantes do Governo do Estado. O Conselho tem caráter normativo e deliberativo, tratando dos assuntos inerentes aos campos funcionais de interesse comum da região. A participação de seus representantes é paritária entre o conjunto das prefeituras e os representantes do Estado.

${ }^{14}$ A AGEM - Agência Metropolitana da Baixada Santista - tem por finalidade integrar a organização, o planejamento e a execução das funções públicas de interesse comum na RMBS.

${ }^{15}$ O COMDEMA - Conselho Municipal de Defesa do Meio Ambiente - é uma unidade colegiada, de caráter consultivo, deliberativo, recursal e de assessoramento do Poder Público Municipal em questões relativas ao equilíbrio ambiental e à melhoria da qualidade de vida local. É composto por membros que representam o poder público, a sociedade civil organizada, podendo ainda vir a ter representantes da iniciativa privada. 
visão conjunta dos tomadores de decisão, o que impede que se consiga lidar eficientemente com os conflitos existentes na região.

Esta falta de integração acaba também por resultar, na maioria dos casos, numa pouca representatividade dos diferentes atores costeiros na tomada de decisão, o que dificulta que as decisões tomadas sejam consensuais. Por outro lado, muitos dos fóruns que pretendem promover uma participação de todos os atores envolvidos no gerenciamento da região, a exemplo do grupo setorial de gerenciamento costeiro, possuem um sistema tripartite, onde o poder público acaba por estar, de fato, em maioria, uma vez que $2 / 3$ dos votos estão repartidos entre o governo estadual e municipal, deixando a sociedade com apenas 1/3 destes votos. Deste modo, a sociedade civil, que tem uma visão mais conservadora do ambiente, acaba geralmente perdendo as questões relativas à proteção e conservação do ambiente natural.

Por último, também foi possível retirar várias ilações relativamente a obstáculos sócio-culturais. Primeiro, sentiu-se que embora já seja de amplo conhecimento a possibilidade de ação participativa na Baixada Santista, este é um procedimento que não está suscitando o devido interesse. Isto foi particularmente visível durante o projeto, pois as reuniões que tiveram maior adesão foram as que objetivavam apenas informar o público do andamento dos trabalhos. Quando se tentou formar um grupo onde as suas vozes seriam determinantes para equacionar soluções para dois graves problemas da região, essa adesão reduziu-se exponencialmente. Estes fatos passam a idéia, portanto, de que os stakeholders estão habituados a uma posição de ouvintes e que não procuram ser mais do que isso.

Foi também curioso verificar que a maior colaboração e participação ativa com o projeto se deu por parte dos representantes dos órgãos governamentais estaduais e, com menor intensidade, dos municipais. Os representantes da sociedade civil organizada participaram apenas como ouvinte, não tendo aproveitado esta oportunidade para se fazer ouvir, com exceção para as instituições de ensino e pesquisa. Poderia parecer demasiadamente pretensioso ou irresponsável avaliar o papel destes atores com base no seu envolvimento apenas no projeto Ecomanage. No entanto, as impressões de vários membros da equipe de pesquisadores com experiência em projetos de cunho social e ambiental na região, e também o relato de Carmo (2004), são concordantes no sentido de que, apesar de 
existirem várias organizações da sociedade civil engajadas na busca de soluções para os problemas da região, ainda é pouco efetivo o seu real comprometimento com essas questões.

Assim, a ação destas organizações é muitas vezes pontual e sem grande impacto, pois não está integrada com outras organizações da mesma natureza ou mesmo governamentais. Apesar dos fóruns de discussão já existentes, estas várias instituições não conseguem concordar quanto a uma linha de ação, o que com certeza resultaria numa influência bem mais forte sobre os acontecimentos da região, pois a vox populi é, de resto, uma das maneiras mais eficientes de obter a vontade política necessária para tomar decisões no sentido das suas reivindicações.

Esta pequena mobilização das organizações da sociedade pode ser também fruto da falta de ações de sensibilização e conscientização da comunidade para as questões ambientais por parte do governo e, consequentemente, embora importante, o resultado dos seus trabalhos permanecem pontuais e dispersos.

Finalmente, mas não por último, existe também a possibilidade de uma falha por parte dos pesquisadores do projeto no sentido de motivar especificamente este grupo de stakeholders. Na realidade, a maior parte dos participantes pesquisadores tinha pouca experiência na organização de reuniões com participantes extraacadêmicos, que exige uma linguagem distinta e técnicas específicas de comunicação. Este foi um aspecto dos quais os pesquisadores se ressentiram durante o desenvolvimento do projeto e uma lição importante é agregar especialistas nesse tipo de técnica de condução de reuniões e de comunicação com o público em geral. Na realidade, a comunidade científica tem despertado recentemente para a importância da comunicação com a mídia, tomadores de decisão e público e a necessidade de melhorar esta comunicação é enfatizada por diversos autores, como Norton (1998); Latour (2004) e Beckers et al. (2006).

Concluindo, os aspectos mais evidentes ao longo do desenvolvimento do projeto foram, portanto, relativos à incipiente visão unificadora entre os representantes dos diversos municípios da Baixada Santista, entre estes e os conselhos ou grupos intermunicipais e com a sociedade civil organizada. As relações do poder público com o terceiro setor são de fato as mais evidentes, pois os interesses econômicos ainda são o motor fundamental do desenvolvimento da região. Estes fatores associados à falta de uma maior articulação entre as organizações da sociedade civil resultam, obviamente, num agravamento dos 
conflitos socioambientais. No entanto, foram igualmente observados vários pontos positivos durante este processo que merecem ser destacados, pois, face ao panorama traçado, eles se revelam como avanços essenciais para que novos caminhos sejam traçados na resolução dos conflitos da Baixada Santista.

\subsubsection{Potencialidades Evidenciadas durante o Processo de Implementação}

Apesar das dificuldades acima discutidas para manter um grupo motivado de stakeholders para o trabalho proposto, foi possível estabelecer boas relações de cooperação com os que permaneceram no grupo, o que pode indicar que existem boas possibilidades para estabelecer futuras parcerias com maior número de atores.

Os stakeholders que compareceram na maior parte das reuniões acabaram por trabalhar ativamente com o projeto desde o seu início. Assim, puderam realmente acompanhar a sua evolução e perceber as potencialidades das ferramentas desenvolvidas durante 0 projeto Ecomanage para ajudar 0 gerenciamento costeiro da região. O seu maior engajamento até o final dos trabalhos é, portanto, compreensível.

Por outro lado, não se conseguiu apurar a razão do não comparecimento às reuniões por parte dos demais stakeholders nem da falta de preenchimento das matrizes. É fato que existe uma real dificuldade em manter fóruns de discussão contínuos com atores comprometidos e operantes para os problemas ou tomadas de decisão da Baixada. Essa falta de engajamento foi sem dúvida sentida pelo projeto, mas outros fatores poderão também explicar a ausência de alguns stakeholders. Algumas hipóteses aventadas para estes fatos foram de que as reuniões coincidiram com outros eventos na região cuja presença desses atores era solicitada; que o próprio consenso inicial nos temas identificados como prioritários gerou a falta de interesse; que a abordagem escolhida pela equipe para lidar com estes temas tenha sido inadequada; que a participação em muitas reuniões de trabalho faz com que as pessoas que eventuamente perdem uma reunião se sintam desestimuladas por acharem que não acompanharão o processo; que a sobrecarga de atividades desestimula a atuação voluntária e finalmente, que tenha havido falha da equipe por 
não ter conseguido explicar concretamente a importância da sua participação e, portanto, não obtendo a motivação necessária.

Além disso, é preciso considerar que embora exista um histórico de ações participativas em diferentes fóruns já estabelecidos na região, pelo fato destas não estarem resultando numa incorporação efetiva das opiniões defendidas pela sociedade civil na elaboração de política públicas, pode estar havendo uma descrença neste modelo de sistema de participativo. Desta forma, pode não haver grande motivação para a participação em outros projetos desta natureza. Considerase, portanto, uma vitória do projeto a formação e manutenção de um grupo de stakeholders, mesmo não tendo a adesão desejada.

Ficou bem claro tanto para a equipe do projeto como para os demais participantes que estas reuniões técnicas serviram como um espaço de colaboração conjunta que procurou ser o mais democrático possível, onde os atores de diversos setores puderam expor suas opiniões de modo geral e também opinar sobre aspectos do desenvolvimento do projeto, o que ainda não é comum na região. Foi manifesta, inclusive, uma grande satisfação por parte dos stakeholders que tiveram participação ativa, pela oportunidade para discutir em conjunto os problemas em questão e também pelos resultados obtidos pelas ferramentas integradoras do projeto para a resolução de conflitos. Pode-se dizer que, se não de forma abrangente, mas completa, os objetivos do projeto foram alcançados pois ao menos representantes de órgãos governamentais estaduais, demonstraram um forte interesse em querer continuar a trabalhar com as ferramentas desenvolvidas.

Um desses stakeholders ao perceber o potencial das ferramentas desenvolvidas para analisar um caso específico de reassentamento de pessoas, manifestou interesse em demonstrar a ferramenta para outros órgãos governamentais, na esperança de que eles também percebam estas ferramentas e metodologias como uma nova abordagem para os problemas e avaliação de projetos na região. Pode-se considerar, portanto, que se formou ao menos um agente multiplicador além da equipe de pesquisadores, o que é fundamental para que se concretize verdadeiramente o objetivo de transferência de conhecimento idealizado pelo projeto Ecomanage inicialmente.

Além do mais, conseguiu-se obter agora, na fase final do projeto, um novo parceiro. Trata-se de um órgão governamental intermunicipal que inicialmente preferiu não colaborar com o projeto, impedidos apenas por questões jurídicas, mas, 
após participar das reuniões e verificar a potencialidade das ferramentas, conseguiu ultrapassar este obstáculo e reiterar seu apoio e vontade em colaborar. Isto mostra, portanto, que existem boas perspectivas para a continuidade dos trabalhos iniciados através do projeto Ecomanage.

Os stakeholders também demonstraram muito apreço em tratar das questões de uma forma multi-setorial e integrada, onde se procurou abordar os problemas do ponto de vista da bacia hidrográfica, sem levar em conta os limites jurisdicionais. Admitiram que era algo inovador para a região e que foi importante para se ter uma visão holística do sistema e conseqüentemente na obtenção de respostas integradoras.

Esta avaliação do ambiente costeiro a partir da bacia hidrográfica, apesar de ter sua importância enfatizada na Conferência de Joanesburgo 92 no próprio título ("Hilltops to oceans") é, de resto, algo de inovador no Brasil. Assim, o Ecomanage poderá representar uma experiência inspiradora para demais projetos. Além do mais, as discussões que estão atualmente ocorrendo no âmbito do governo federal visando organizar a integração da gestão de bacias hidrográficas com a gestão dos sistemas estuarinos e zonas costeiras, indicam que este será o caminho que o governo irá seguir. As ferramentas do projeto Ecomanage representam, portanto, uma oportunidade para os municípios já começarem a trabalhar sob essa ótica.

Outro ponto importante a destacar é que se conseguiu construir uma base única de informação que centralizou todos os dados obtidos pelo projeto (tanto os já existentes, como os resultantes das campanhas de amostragem). Esta base de dados será disponibilizada para o público após o término do projeto. Isto significa que informações fundamentais, como a discriminação das contribuições antrópicas (tanto de origem difusa como pontual) para o estuário ou a avaliação (quantitativa e qualitativa) do estado do mangue ${ }^{16}$, poderão ser encontradas e facilmente utilizadas. A existência de uma base desta natureza representará, sem dúvida, uma importante fonte de subsídios para o gerenciamento socioambiental da região.

Finalmente, o projeto Ecomanage conseguiu aproximar instituições governamentais com instituições de pesquisa e ensino (executantes do projeto). Isto

\footnotetext{
${ }^{16}$ A última avaliação que se fez desta natureza na região data de 1988. Além do mais, foram realizadas inúmeras pesquisas inovadoras na área, como por exemplo, estimativas de produtividade do mangue, algo nunca feito anteriormente na área e cujo conhecimento é vital estimar a contribuição do mangue no seu estado atual para a produtividade do estuário.
} 
representa, sem dúvida, uma grande conquista num país onde o potencial técnicocientífico para o gerenciamento costeiro está sendo sub-aproveitado, como anteriormente discutido. Acredita-se, portanto, que as parcerias de trabalho que foram e estão sendo estabelecidas são indicativas de que a formalização de protocolos de cooperação entre estas duas instâncias para auxílio no processo de GCl é uma possibilidade fortemente concretizável para a região.

\section{Conclusões}

Apresentam-se em seguida as principais conclusões obtidas pela análise realizada ao longo desse trabalho. Em relação à implementação do projeto Ecomanage na Baixada Santista, conclui-se que:

1. O envolvimento dos stakeholders num projeto de gestão costeira integrada é crucial para o sucesso de sua implementação. Além disso, verificou-se que, independentemente do tipo de participação objetivada, deve-se sempre procurar que ela ocorra o mais cedo possível, para assegurar que os stakeholders se sintam invariavelmente parte integrante do processo e portanto, compreendam que todos têm responsabilidades e importância para a gestão de zonas costeiras.

2. O retorno continuado do andamento dos trabalhos para os stakeholders é o segundo ponto crucial para garantir o sucesso de um projeto de $\mathrm{GCl}$. No projeto Ecomanage, as reuniões com participação sob forma consultiva serviram para apresentar o andamento dos trabalhos, mas, sobretudo, para dar retorno, demonstrando onde e como a informação obtida (e muitas vezes facultada pelos próprios stakeholders) foi utilizada e para quê. Foi esse retorno que garantiu que o projeto tivesse o devido apoio e que possibilitou que num momento posterior se montasse um grupo específico de trabalho com um intuito mais participativo. Foi também esta participação que possibilitou formar agentes multiplicadores e dar continuidade ao trabalho.

3. A equipe técnica envolvida no projeto deve estar capacitada tecnicamente para analisar tanto aspectos ecológicos como socioeconômicos das questões consideradas. Essa equipe deve, portanto, ser composta por especialistas 
nessas áreas, mas que saibam cruzar as informações, sendo a integração interdisciplinar uma condição essencial para o sucesso.

4. É também essencial que exista um facilitador nessa equipe que tenha experiência em conduzir os processos participativos. A falta de uma pessoa capacitada nesse sentido no projeto Ecomanage, embora não tenha sido impeditiva para a condução desses processos, pode ter gerado perda de eficiência na interação com os stakeholders.

5. As ferramentas utilizadas para desenvolver um projeto desta natureza devem ser tecnicamente robustas, mas de fácil compreensão em seus aspectos fundamentais para ganhar confiabilidade por parte dos stakeholders.

6. Essas ferramentas devem também se apresentar como de manejo simples após sua construção para garantir o interesse e facilidade de multiplicação do uso.

7. A equipe de pesquisadores deve ter receptividade, rapidez e capacidade para se adaptar a novas situações que se desenvolvem ao longo do projeto, de maneira a poder adequar os procedimentos de acordo.

8. É importante definir numa primeira fase poucos e relevantes objetivos para tratar com o projeto, devendo ser focadas questões chave e para as quais existam condições políticas, técnicas e culturais de serem trabalhadas dentro do prazo previsto no projeto.

9. O tempo é um fator fundamental a ser considerado, pois independentemente das facilidades financeiras e capacitação técnica, o desenvolvimento das interações humanas tem uma dinâmica própria, que deve ser contabilizado no processo de planejamento.

10.A desarticulação das organizações sociais existentes na Baixada está incapacitando-as de terem uma ação concertada de forma a se fortalecerem perante as instâncias de tomada de decisão, o que pode levar a perdas de posições políticas e à desmotivação, sendo que estes fatores podem se tornar impeditivos para a perfeita realização de uma participação democrática.

11. O lobby econômico tem uma grande interferência sobre os tomadores de decisão da região, o que tem enviezado as ações em prol de um desenvolvimento sustentado. 
12. Assim, verifica-se que não existe vontade política para se lidar efetivamente com os conflitos ambientais, sendo o desenvolvimento econômico a prioridade das agendas políticas.

13. A participação e colaboração heterogênea verificada por parte dos representantes dos municípios e outros órgãos governamentais permite concluir que é frágil a visão verdadeiramente metropolitana da região por parte desses representantes governamentais, o que acaba por resultar em ações setorizadas e confinadas aos limites jurisdicionais de cada município, dificultando a resolução efetiva dos problemas socioambientais da região.

14. A dificuldade de obtenção de dados, assim como a inexistência de informações em alguns casos foram importante contratempo no desenvolvimento dos trabalhos do projeto Ecomanage, o que acabou por impedir o aprofundamento de outros aspectos.

15. A avaliação num projeto de gestão costeira integrada é fundamental para o aprimoramento de projetos dessa natureza.

Com relação à situação do projeto Ecomanage no contexto da evolução dos princípios da gestão costeira integrada, a análise realizada permitiu concluir que:

16.O projeto foi desenvolvido de acordo com o enfoque ecossistêmico, adaptativo, integrativo e participativo, como preconizado pela $\mathrm{GCl}$ em nível mundial, o que foi determinante para o seu sucesso.

17.As lições retiradas da implementação do projeto analisado são concordantes com os fatores considerados condicionantes da $\mathrm{GCl}$, a saber: o projeto deve ser adaptado ao contexto político, social, cultural, econômico e ambiental do local onde vai ser implementado; devem ser atendidas as características do sistema de governança do local; as partes interessadas devem ser envolvidas ativamente no processo de tomada de decisão; e deve ser repassada informação adequada dos dados obtidos e do trabalho realizado para os atores envolvidos no processo.

18.Verifica-se que, apesar do país já apresentar um quadro legal e institucional que permite e estrutura a gestão costeira sob uma perspectiva integrada, ainda existem lacunas a serem preenchidas e que foram ressentidas no 
contexto do desenvolvimento do projeto Ecomanage, como por exemplo, a integração formal entre a gestão das bacias hidrográficas e a gestão costeira.

19.Também não se verifica uma integração efetiva entre as instâncias locais com responsabilidades e competências na gestão costeira, que pode comprometer a maior eficiência de projetos da natureza do Ecomanage.

\section{Considerações finais}

Pode-se considerar que o trabalho realizado pelo projeto Ecomanage na Baixada Santista perante um cenário de tão grande complexidade, tanto quanto à natureza dos conflitos socioambientais, como à das respostas possíveis, foi um sucesso.

Os resultados obtidos não se resumiram ao desenvolvimento de ferramentas gerenciais, apesar destas terem demonstrado grande aplicabilidade e utilidade para o desenho de soluções e respostas gerenciais eficientes e devidamente embasadas. O grande avanço do projeto Ecomanage está antes relacionado ao respaldo que obteve por parte dos atores envolvidos em relação à abordagem com que tratou as questões socioambientais da região.

Muito embora a participação dos stakeholders não tenha sido aquela idealizada pela equipe (sobretudo em relação ao envolvimento da sociedade civil), a forte participação de representantes do governo, que constituem geralmente os atores mais reticentes e muitas vezes também carentes de embasamento técnico para nortear suas ações, foi uma importante conquista.

Por outro lado, conseguiu-se formar ao menos um agente multiplicador do trabalho concretizado pelo projeto fora do grupo, assim como estabelecer importante parceria com outras duas instituições. O fato destas instituições serem todas governamentais, estando envolvidas direta e indiretamente na gestão da região, pode significar que se tenha possivelmente aberto novas oportunidades para o gerenciamento costeiro na Baixada Santista. Obviamente que ainda há um longo percurso a percorrer para explorar devidamente estas oportunidades, estando o seu impacto dependente da dinâmica com que o diálogo entre estes novos parceiros 
continuar a ocorrer e também do empenho das partes. No entanto, estes são os passos normais de um processo iterativo como a $\mathrm{GCl}$ pretende ser.

Estes resultados são particularmente importantes perante as perspectivas de desenvolvimento que se desenham para a região, onde importantes empreendimentos estão previstos que podem gerar grande impacto ambiental se não forem muito bem delineados nessa questão. Um desses exemplos é a expansão do Porto de Santos, cujo projeto já foi iniciado através da construção do terminal da EMBRAPORT sobre área de manguezal, região protegida por legislação. É digno de nota que esta área, que foi inicialmente considerada como Z1 (mais restritiva) na proposta de zoneamento ecológico-econômico atualmente em discussão, foi transformada em Z5 (menos restritiva) pelo próprio grupo setorial atual do GERCO, de forma que uma vez o ZEE aprovado, os projetos de expansão do Porto terão maior facilidade para avançar. Este caso é, portanto, bastante representativo quanto à natureza dos interesses locais, tanto dos municípios, como do setor privado, e do poder que estes têm na região.

Esta situação mostra claramente como o gerenciamento costeiro na região e no país necessita cada vez mais que a sociedade civil organizada intervenha ativamente e concertadamente no processo, conforme garantido pela legislação vigente, assumindo a responsabilidade conjunta que lhe é destinada a fim de garantir a todos o "direito ao meio ambiente ecologicamente equilibrado, bem de uso comum do povo e essencial à sadia qualidade de vida, impondo-se ao Poder público e à coletividade o dever de defendê-lo e preservá-lo para as presentes e futuras gerações", conforme preconizado no art. 255 da Constituição Brasileira de 1988 (BRASIL, 2003).

Desta forma, embora se tenha conseguido estabelecer com o presente projeto "apenas" parcerias entre universidades locais e setor público, projetos da natureza do Ecomanage, mesmo que em menor escala, representam uma importante oportunidade para capacitar a sociedade com ferramentas potentes para representar e defender os seus interesses com o devido embasamento técnico e científico. Espera-se, assim, que esta oportunidade possa ser aproveitada pelas várias ONGs e OSCIPs de cunho socioambiental que já existem na Baixada Santista e que as suas vozes ganhem a devida importância no desenho dos caminhos futuros de desenvolvimento da região. 


\section{Referências bibliográficas}

AFONSO, C. M. (2006). A paisagem da Baixada Santista: Urbanização, Transformação e Conservação. Edusp, Sao Paulo. 310 p.

AGARDY, T. \& ALDER, J. 2005. Coastal Systems. In: Ecosystems and human wellbeing - Current state and trends: findings of the condition and trends working group. HASSAN, R; SHOLES, R. \& ASH, N, (Ed.) The millennium ecosystem assessment series, v. 1. Washington DC: Island Press, p. 515-543.

AGEE, J. K. \& JOHNSON, D.R. 1988. Ecosystem Management for Parks and Wilderness. Seattle: University of Washington Press.

AGEM. 2005. PRIMAHD - Programa Regional de Identificação e Monitoramento de Áreas de Habitação Desconforme da R.M.B.S. Relatório Final. 565p.

AGGARWAL, R. M. 2006. Globalization, local ecosystems and the rural poor. World Development, v. 34, n. 8, p.1405-1418.

ASMUS, M. \& KITZMANN, D. 2004. Gestão costeira no Brasil: estado atual e perspectivas. In: ECOPLATA - Programa de apoyo a la gestion integrada en la zona costera Uruguaya. Montevidéo: Uruguai.

BARRAGÁN MUÑOZ, J.M. 2001. The Brazilian National Plan for Coastal Management (PNGC). Coastal Management, v. 39, p. 137-156.

BARRAGÁN MUÑOZ, J. M.; DADON J. R.; MATTEUCCI, S. D.; MORELLO, J. H.; BAXENDALE, C. \& RODRÍGUEZ, A. 2003. Preliminary Basis for an Integrated Management Program for the Coastal Zone of Argentina. Coastal Management, v. 31, p. $55-77$.

BARUSSEAU P., BRIGAND, L., DENIS, J., GÉRARD B., GRIGNON-LOGEROT, C., HÉNOCQUE, Y., \& LOINTIER, M. 1997. Methodological guide to integrated coastal zone management. IOC Manuals and Guides 36. Paris: UNESCO.

BECKERS, T.; WOODROW, P. E.; GIANESELLA, S. M. F., KLENNER, L. G.; KLINK, C. A.; TOURRAND, J. F. \& WEINGART, P. 2007. Communicating science to the media, decision makers and the public. IN: TIESSEN, H.; BRKLACICH, M.; BREULMANN, G. \& MENEZES, R. S. C. (ed). Communicating global change science to society - An assessment and case studies. Washington: Scope Island Press.

BOWEN, R. E. \& RILEY, C. 2003. Socio-economic indicators and integrated coastal management. Ocean \& Coastal Management, v.46, p.299-312.

BRASIL. 1988a. Leis, Decretos. Lei n 7661, de 16 de Maio de 1988. 
BRASIL. 2003. Constituição da República Federativa do Brasil (1988). Obra coletiva de autoria da Editora Revista dos Tribunais. Coord. Giselle de Melo Braga Tapai. $8^{a}$. ed. rev. atual. e ampl. São Paulo: Ed.Revista dos Tribunais.

BURKE, L.; KURA, Y.; KASSEM, K.; REVENGA, C.; SPALDING, M. \& MCALLISTER, D. 2001. Pilot analysis of global ecosystems: Coastal ecosystems. Washington DC: World Resources Institute.

CARMO, S. 2004. Câmara e Agenda 21 Regional - Para uma rede de cidades sustentáveis: A região metropolitana da Baixada Santista. Tese de Mestrado, Universidade Federal de São Carlos.

CETEC/CETAM. (Centro Tecnológico de Lins - SP / Centro Técnico de Engenharia Ambiental). Minuta Preliminar do Relatório de Situação dos Recursos Hídricos da UGRHI7. Comitê da Bacia Hidrográfica da Baixada Santista, Relatório Zero, 2000, $238 \mathrm{p}$.

CHUA, T. E. 1993. Essential elements of integrated coastal zone management. Ocean \& Coastal Management, v. 21., p. 81-108.

CHUA, T. E. 1998. Lessons learned from practising integrated coastal management in Southeast Asia. Ambio, v. 27., n. 8, p. 599-610.

CHUA, T. E.; BONGA, D. \& BERMAS-ATRIGENIO, N. 2006. Dynamics of integrated coastal management: PEMSEA's Experience. Coastal Management, v. 34, p. 303-322.

CICIN-SAIN, B. 1993. Sustainable Development and Integrated Coastal Management. Ocean \& Coastal Management, v. 21, p. 11-43.

CICIN-SAIN, B.; KNECHT, R. W. \& FISK, G. 1995. Growth in capacity for integrated coastal management since UNCED: an international perspective. Ocean \& Coastal Management, v. 29, p. 93-123.

CICIN-SAIN, B. \& KNECHT, R. W. 1998. Integrated coastal and ocean management: concepts and practices. Washington DC: Island Press. 517p.

CICIN-SAIN, B.; BERNAL, P.; VANDEWEERD, V.; BELFIORE, S. \& GOLDSTEIN, K. 2002. A guide to oceans, coasts and islands at the World Summit on Sustainable Development. Delaware: Center for the Study of Marine Policy.

CIESIN. 2003. National aggregates of geospatial data: Population, landscape and climate estimates. Palisades, NY: Columbia University.

CLARK, J. R. 1997. Coastal zone management for the new century. Ocean \& Coastal Management, v. 37, n. 2, p. 191-216.

CMMAD. 1988. Nosso futuro comum. Rio de Janeiro: FGV. 
CNUMAD. 1992. Conferência das Nações Unidas sobre Meio Ambiente e Desenvolvimento: Agenda 21. Brasílla: Senado Federal, Subsecretaria de Edições Técnicas. Disponível em: <http://www.ambiente.sp.gov.br/agenda21.htm>. Acesso em: 15 fev 2007.

CODESP. Museu do Porto de Santos. História do Porto de Santos. Santos, [199-]. Disponível em: <http://portodesantos.com.br> Acesso em: 10 set. 2007.

COSTANZA, R.; D'ARGE, R.; DE GROOT, R.; FARBER, S.; GRASSO, M.; HANNON, B.; LIMBRUG, K.; NAEEM, S.; O’NEILL, R. V.; PARUELO, J.; RASKIN, R. G.; SUTTON, P. \& VAN DEN BELT, M. 1997. The value of the world's ecosystem services and natural capital. Nature, v. 387, p. 253-260.

COSTANZA, R.; ANDRADE, F.; ANTUNES, P.; VAN DEN BELT, M.; BOERSMA, D.; BOESCH, D.F.; CATARINO, F.; HANNA, S.; LIMBURG, K.; LOW, B.; MOLITOR, M.; PEREIRA, J.G.; RAYNER, S.; SANTOS, R.; WILSON, J. \& YOUNG, M. 1998. Principles for sustainable governance of the oceans. Science, v. 281, p. 198-199.

CROSSLAND, C.J. \& KREMER, H. H. 2001. Coastal zones: ecosystems under pressure. In: OCEANS AND COASTS AT RIO +10 - GLOBAL CONFERENCE. Paris: UNESCO.

DALY,H. E. 1996. Beyond growth. The economics of sustainable development. Boston: Beacon Press.

DIEGUES, A.C. 2001. Desenvolvimento sustentável ou sociedades sustentáveis: da crítica dos modelos aos novos paradigmas. IN: DIEGUES, A. C. Ecologia Humana e Planejamento Costeiro. São Paulo: NUPAUB - USP, 225p.

EC. 2003. Common implementation Strategy for the Water Framework Directive (200/60/EC). Guidance Document $n^{\circ}$ 8: Public participation in relation to the Water Framework Directive. Luxembourg: European Communities.

EEA. 1999. Environmental indicators: typology and overview. Technical Report $n^{\circ} 25$. Copenhagen: European Environment Agency.

FAO. 1998. Integrated coastal area management and agriculture, forestry and fisheries. Scialabba, N. (Ed.) FAO Guidelines. Environment and Natural Resources Service, Rome: FAO, 256p.

GESAMP. 1996. The contribution of science to integrated coastal management. GESAMP Reports and Studies n. 61. Rome: FAO.

GESAMP. 2001. A sea of troubles. GESAMP Reports and Studies n. 70, 35 p. 
HILDEBRAND, L. 2002. Integrated coastal management: lessons learned and challenges ahead. In: MANAGING SHARED WATER/COASTAL ZONE CANADA. Hamilton: Canada.

HOLLING, C. S. 1978. Adaptive Environmental Assessment and Management. Chichester: John Wiley \& Sons.

HUPPERT, H. E. \& SPARKS, R. S. J. 2006. Extreme natural hazards: population growth, globalization and environmental change. Phil. Trans. R. Soc. A, n. 364, p. $1875-1888$.

IBGE. 2000. Censo Demográfico 2000 - Agregado de Setores Censitários dos Resultados do Universo, Instituto Brasileiro de Geografia e Estatística - IBGE.

IGBP. 2001. Global change and the earth system: A planet under pressure. IGBP Series n. 4.

IGBP. 2003. Marine ecosystems and clobal change. IGBP Series n. 5.

IPCC. 2001. Climate Change 2001: Impacts, Adaptation, and Vulnerability: Contribution of working group II to the third assessment report of the Intergovernmental Panel on Climate Change. MAcCARTHY, J. J.; CANZIANI, O. F.; LEARY, N. A.; DOKKEN, D.J. \& WHITE, K. S. (Eds)., Cambridge: Cambridge University Press. 1005p.

IPCC. 2007. Climate change 2007 - The physical science basis: Contribution of working group I to the fourth assessment report of the Intergovernmental Panel on Climate Change. SOLOMON, S., D. QIN, M. MANNING, Z. CHEN, M. MARQUIS, K.B. AVERYT, M. TIGNOR AND H.L. MILLER (Eds)., Cambridge: Cambridge University Press. 996p.

JAKOB, A. 2003. Análise Sócio-Demográfica da Constituição do Espaço Urbano da Região Metropolitana da Baixada Santista no período 1960-2000. Tese de Doutorado. Instituto de Filosofia e Ciências Humanas da Universidade Estadual de Campinas.

JICKELLS, T. D. 1998. Nutrient biogeochemistry of the coastal zone. Science, v. 281, p. 217-222.

KAY, R. \& ALDER J. 2005. Coastal planning and management. 2nd Edition. London: Taylor \& Francis.

KENCHINGTON, R. \& CRAWFORD, D. 1993. On the meaning of integration in coastal zone management. Ocean \& Coastal Management, v. 21, p- 109-127.

KRISTENSEN, P. 2004. The DPSIR Framework. Paper presented at the 27-29 September 2004 workshop on a comprehensive / detailed assessment of the vulnerability of water resources to environmental change in Africa using river basin approach. UNEP Headquarters, Nairobi, Kenya. 
LAMPARELLI, M.L.; COSTA, M.P.; PRÓSPERI, V.A.; BEVILACQUA, J.E.; ARAÚJO, R.P.A.; EYSINK, G.G.L.; POMPÉIA, S. 2001. Sistema Estuarino de Santos e São Vicente. Relatório Técnico CETESB. São Paulo, SP. 178p.

LATOUR, B. 2004. Politics of nature: How to bring the sciences into democracy. Cambridge: Harvard University Press.

LIN, T., XUE, X. Z. \& LU, C. Y. 2007. Analysis of coastal wetland changes using the DPSIR model: A case study in Xiamen, China. Coastal Management, v.35, p.289-303.

MEA. 2005a. Ecosystems and human well-being: Synthesis. Washington DC: Island Press.

MEA. 2005b. Ecosystems and human well-being - Current state and trends: Findings of the Condition and Trends Working Group. HASSAN, R; SHOLES, R. \& ASH, $\mathrm{N}$, (Ed.) The millennium ecosystem assessment series, v. 1. Washington DC: Island Press.

MEADOWS, D. H. 1972. The limits to growth. New York: Universe Books.

MORIN, E. 1999. Por uma reforma do pensamento. IN: PENA-VEGA, A., \& NASCIMENTO, E. P. (orgs). O pensar complexo: Edgar Morin e a crise da modernidade. 3.ed. Rio de Janeiro: Garamond.

MORIN, E. 2001. Introdução ao Pensamento Complexo. 3. ed. Lisboa: Instituto Piaget. $177 p$.

MUNDA, G. 1995. Multi-criteria Evaluation in a Fuzzy Environment, Heidelberg: Physica-Verlag. 255p.

NORTON, B. G. 1998. Improving ecological communication: The role of ecologists in environmental policy formation. Ecological Applications, v. 8., n. 2, p. 350-364.

OECD. 1993. Coastal zone management: Integrated policies. Paris: Organization for Economic Co-operation and Development.

OLSEN, S.; TOBEY, J, \& KERR, M. 1997. A common framework from ICM experience. Ocean \& Coastal Management, v. 37, n. 2, p.155-174.

OLSEN, S.; TOBEY, J. \& HALE, L. 1998. A learning-based approach to Coastal Management. Ambio, v. 27, n. 8, p. 611-619.

OLSEN, S.; LOWRY, K.; TOBEY, J. 1999. A Manual for Assessing Progress in Coastal Management. Coastal Management Report \# 2211. The University of Rhode Island. CRC. 68p.

OLSEN, S. \& CHRISTIE, P. 2000. What are we learning from tropical coastal management experiences? Coastal Management, v. 28, p. 5-18. 
OLSEN, S. 2002. Assessing progress toward the goals of coastal management. Coastal Management, v. 30, p. 325-345.

OLSEN, S. 2003. Coastal Stewardship in the anthropocene. In: OLSEN, S. (Ed), Crafting coastal governance in a changing world. Narragansett: CRC/USAID, University of Rhode Island, p.5-35.

PAK, A. \& FARAJZADEH, M. 2007. Iran's integrated coastal management plan: Persian Gulf, Oman Sea and southern Caspian Sea coastlines. Ocean \& Coastal Management, v. 50, p. 754-773.

POLETTE, M. \& VIEIRA, P.F. 2005. Avaliação do processo de gerenciamento costeiro no Brasil: bases para discussão. Florianópolis: UFSC. $285 p$

POLETTE, M.; REBOUÇAS, G.N.; FILARDI, A.C. \& VIEIRA, P.F. 2006. Rumo à gestão integrada e participativa de zonas costeiras no Brasil: percepções da comunidade científica e do terceiro setor. Gestão Costeira Integrada, v. 5, p4348.

POLETTE, M., VIEIRA, P.F.; FILARDI, C.L. \& REBOUÇAS, G.G. 2008a. Fatores condicionantes de desarticulação das políticas públicas incidentes na zona costeira brasileira. Trabalho submetido ao Congresso Brasileiro de Oceanografia, Fortaleza.

POLETTE, M., VIEIRA, P.F.; FILARDI, C.L. \& REBOUÇAS, G.G. 2008b. Análise das parcerias entre os programas estaduais de gerenciamento costeiro e as instituições de pesquisas que atuam no litoral brasileiro. Trabalho submetido ao Congresso Brasileiro de Oceanografia, Fortaleza.

REBOUÇAS, G. N.; FILARDI, A.C.L. \& VIEIRA, P. F. 2006. Gestão integrada e participativa da pescas artesananal: potencialidades e obstáculos no litoral ddo estado de Santa Catarina. Ambiente \& Sociedade, v. 9, n. 2, p.83-104.

ROMEIRO, A. R. 1999. Globalização e meio ambiente. Texto para discussão, IE/UNICAMP. n. 91. Campinas.

SACHS, I. 1986. Ecosdesenvolvimento: Crescer sem destruir. Revista dos Tribunais Ltda (Ed). São Paulo: Edições Vértice.

SAMPAIO, A. F. P., SIMÕES, J. \& TELÉSFORO, J. 2007. Socioeconomic data sets, Deliverable 1.9, Ecomanage.

SANTOS, R.; ANTUNES, P.; BAPTISTA, G.; MATEUS, P. \& MADRUGA, L. 2006. Stakeholder participation in the design of environmental policy mixes. Ecological Economics, v. 60, n. 1, p. 100-110. 
SCARABELLO FILHO, S. 2005. O artífice e a ferramenta: a participação pública na gestão ambiental. Tese de doutorado. Faculdade de Engenharia Civil, Arquitectura e Urbanismo da Universidade de Campinas.

SCHREIBER, S. G.; BEARLIN, A. R.; NICOL, S. J. \& TODD, C. R. 2004. Adaptive management: a synthesis of current understanding and effective application. Ecological Management \& Restoration, v. 5, n. 3, p. 177-182.

SHERMAN, K. \& Duda, A. M. 1999. An ecosystem approach to global assessment and management of coastal waters. Mar. Eco. Prog. Ser. v. 190, p.271-287.

SMALL, C. \& NICHOLLS, R. J. 2003. A global analysis of human settlement in coastal zones. Journal of Coastal Research, v.19, n. 3, p. 584-599.

SORENSEN, J. 1993. The international proliferation of integrated coastal zone management efforts. Ocean \& Coastal Management, v. 21, p. 45-80.

SORENSEN, J. 1997. National and international efforts at integrated coastal management: Definitions, achievements and lessons. Coastal Management, v. 25 , p. 3-41.

SORENSEN, J. 2002. Baseline 2000 background report: The status of integrated coastal management as an international practice. Second Iteration.

SPRAGUE, R.H. AND WATSON, H.J. 1986. Decision support systems: putting theory into practice. New Jersey: Prentice Hall.

STAVE, K. 2002 Using system dynamics to improve public participation in environmental decisions. System Dynamics Review, v.18, n. 2, p. 139-167.

STOJANOVIC, T.; BALLINGER, R. C. \& LALWANI, C. S. 2004 Successful integrated coastal management: measuring it with research and contributing to wise practice. Ocean \& Coastal Management, v. 47, p. 273-298.

TOBEY, J. \& VOLK, R. 2002. Learning frontiers in the practice of integrated coastal management. Coastal Management, v.30, n.4, p. $285-298$.

TURNER, R. K.; SUBAK, S. \& ADGER, W. N. 1996. Pressures, trends and impacts in coastal zones: Interactions between socioeconomic and natural systems. Environmental Management, v.20, n. 2, p. 159-173.

UN. 2002. Plan of implementation of the World Summit on Sustainable Development. In: Report of the World Summit on Sustainable Development. New York: United Nations.p. 139-147.

UNEP. 1992. Rio Declaration on Environment and Development. Disponível em $<$ http://www.unep.org/Documents.Multilingual/Default.asp?DocumentID=78\&Artic lelD $=1163>$. 
UNEP. 1995. Guidelines for integrated management of coastal and marine areas with special reference to the Mediterranean basin. UNEP Regional Seas Reports and Studies, n. 161. Nairobi: United Nations Environment Programme.

UNEP. 2002. Global environment outlook 3: Past, present and future perspectives. Nairobi: UNEP.

UNEP. 2006. Marine and coastal ecosystems and human well-being: A synthesis report based on the findings of the Millennium Ecosystem Assessment. Nairobi: UNEP. $76 p$.

UNEP/GPA. 2006. The State of the Marine Environment: Trends and processes. The Hague: UNEP/GPA. 39p.

VALLEGA, A. 1993. A conceptual approach to integrated coastal management. Ocean \& Coastal Management, v. 21, p. 149-162.

VALLEGA, A. 1999. Fundamentals of integrated coastal management. Dordrecht: Kluwer Academic Publishers. 264p.

VAN DEN BELT, M. 2004. Mediated modelling - A system dynamics approach to environmental consensus building. Washington: Island Press. 340p.

VITOUSEK, P.M; MOONEY, H. A.; LUBCHENCO, J. \& MELILLO, J. M. 1997. Human domination of earth's ecosytems. Science, v. 277, p. 494-499.

VON BODUNGEN, B. \& TURNER, R. K. 2001. Science and integrated coastal management: An introduction. In: VON BODUNGEN, B. \& TURNER, R. K. (Ed) Science and integrated coastal management. Berlin: Dahlem University Press, p.1-14.

WHITE, A.T.; CHRISTIE, P., D'AGNES, H.; LOWRY, K. \& MILNE, N. 2005. Designing ICM projects for sustainability: Lessons from the Phillipines and Indonesia. Ocean \& Coastal Management, v. 48, p. 271-296.

WORLD BANK. 1996. Guidelines for integrated coastal zone management. Environmentally Sustainable Development Studies and Monographs Series No. 9. Post, J. C. \& Lundin, C. G. (Ed). Washington DC, The World Bank.

WRI. 2000. A guide to world resources 2000-2001 - People and ecosystems: The fraying web of life. Washington DC: World Resources Institute.

YOUNG, M.D. (1992). Sustainable Investment and Resource Use. Equity, Environmental Integrity and Economic Efficiency. Man and Biosphere Series, v. 9. Paris: UNESCO and Parthenon Publishing Group. 
YOUNG, A. \& FUSCO, W. 2006. Espaços de Vulnerabilidade Sócio-Ambiental para a população da Baixada Santista: identificação e análise de áreas críticas. XV Encontro Nacional de estudos Populacionais, Caxambu, MG. 